Historic, Archive Document

Do not assume content reflects current scientific knowledge, policies, or practices. 



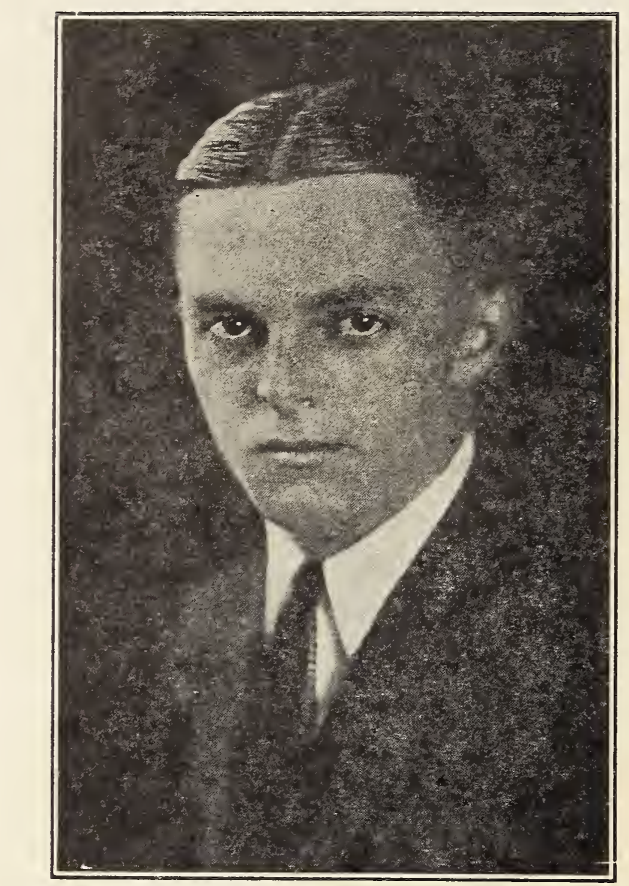

1901

WATSON S. WOODRUFF, JR.

With deep sorrow we announce the death at his home at Orange,

Connecticut, August 21st, 1929, of our

MR. WATSON S. WOODRUFF, Jr., age twenty-eight years, only son of Watson S. and Harriett H. Woodruff, suffered a broken neck at

Easthampton, Massachusetts, December 13 th, 1925.

S. D. WOODRUFF \& SONS

Orange, Connecticut, August 24th, 1929

Watson S. Woodruff, Jr., was born at Orange, Connecticut, on January 7th, 1901. He was graduated at Yale University in 1923 and took a post-graduate course at Cambridge University, Cambridge, England.

In June of 1924, Watson entered the employ of S. D. Woodruff \& Sons. On December 13th, 1925, while on a business trip, he had a collision at Easthampton, Massachusetts, with a horse-drawn, unlighted, rubber-tired buggy, driven by an intoxicated man, at about 6:00 o'clock in the evening. Watson sustained a broken neck. For many days his life was despaired of. He remained in the hospital at Northampton, Massachusetts, for over three months, after which he was removed to his home in Orange, Connecticut. For three years, eight months and eight days he survived, being mentally alert at all times, but physically a totally helpless cripple.

Notwithstanding this physical handicap, Watson made intensive study in research work in the seed business, gathering together from the four corners of the earth novelties and new discoveries in the various vegetable families and assisted in developing many unusually fine strains of seeds. He was able to personally supervise for two years the trial-grounds of S. D. Woodruff \& Sons, being rolled into the trial-gardens in his wheel bed. His personal experiments resulted in gathering much valuable information and data, and at the same time occupied his mind in a most helpful manner. He was able to receive visitors, who came by the hundreds to see him, always in a most cheerful attitude, with never an outward sign of the intense pain which he constantly suffered.

It will be remembered by many of Watson's close friends that his only brother, Stiles D. Woodruff, 2nd, died on June 7th, 1924, at the age of 29 years. 


\section{0}

Messrs. S. D. Woodruff \& Sons give no warranty, expressed or implied, as to description, quality, productiveness, or any other matter of any seeds, plants, bulbs, etc., it sells and will not be responsible for the crop.

\section{A FEW SPECIALTIES OF MERIT FOR MARKET GARDENERS}

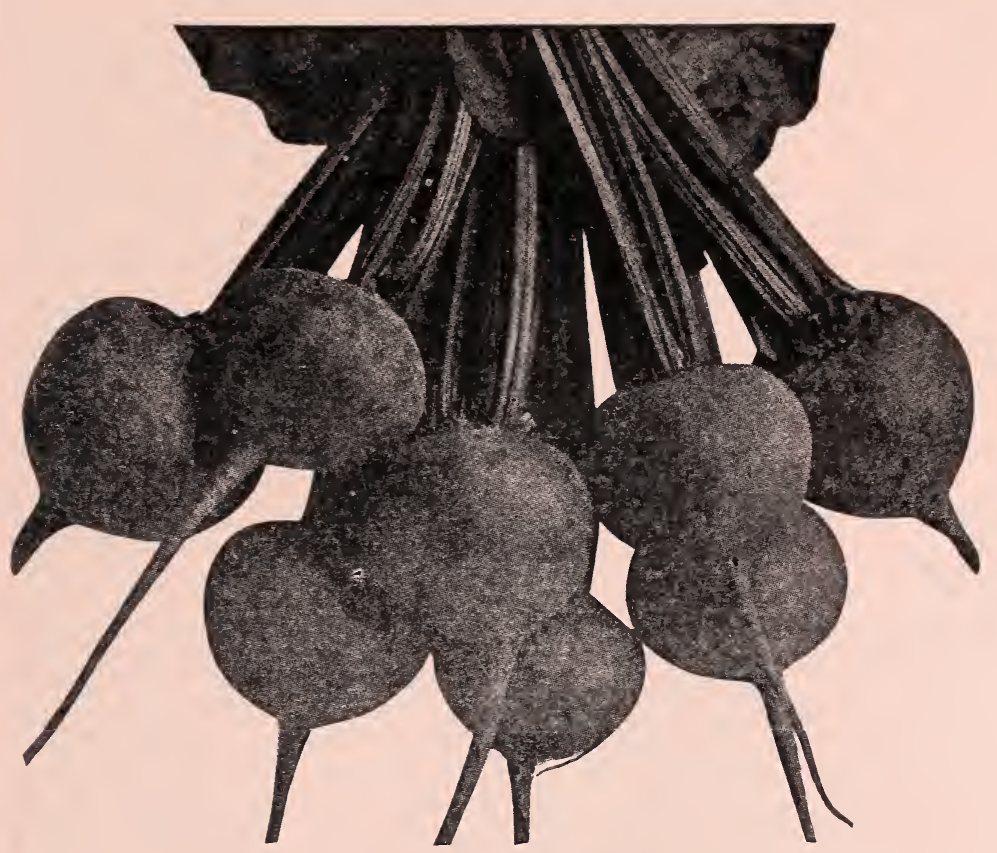

EARLY WONDER -

The Best Beet on the Market-It is the earliest, the most perfect shaped, finest appearing bunch Beet on the market. Beautiful and dark colored, small top, single small tap root, excellent keeper, truly the ideal Beet. Used not only as a bunch Beet, but grown extensively for late fall sowing because it grows two weeks quicker than any other Beet worth while. Because of its perfect shape it is very desirable for Bushel Beets -it is preeminently the best Bunch Beet ever introduced. Pkt. 10c; oz. $20 \mathrm{c} ; 1 / 4$ lb., $50 \mathrm{c} ; 1 \mathrm{lb}$., $\$ 1.25 ; 10$ lbs., $\$ 10.00$.

Early Wonder Beet

"It's Woodruff's Own The Best Beet Grown."

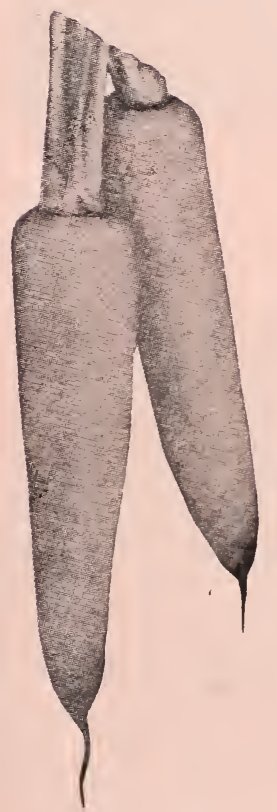

Hutchinson

Carrot

\section{HUTCHINSON}

\section{CARROT}

Note from photograph this is a superior select long strain, averaging 7 to 9 inches in length or 1 to $1 \frac{1 / 2}{\text { inches longer }}$ than our regular stock of Uanvers Improved. It is a perfect shaped blunt ended Carrot. Fine both for Bunching and Bulk. Pkt. $10 \mathrm{c}$; oz. 20c; $1 / 4$ lb $\$ 1.50$; lb $\$ 5.00$.

\section{EARLY SNOWBALL}

CAULIFLOWER. - This variety is the standard by which all others are judged. It makes the smoothest and most solid heads. An extra early good sized delicately textured strain. Its erect sturdy compact plants are very sure heading. It will please the most exacting grower.

Pkt. 25c: oz. $\$ 2.50$ : 1/4 tb $\$ 8.00$; to $\$ 30.00$.

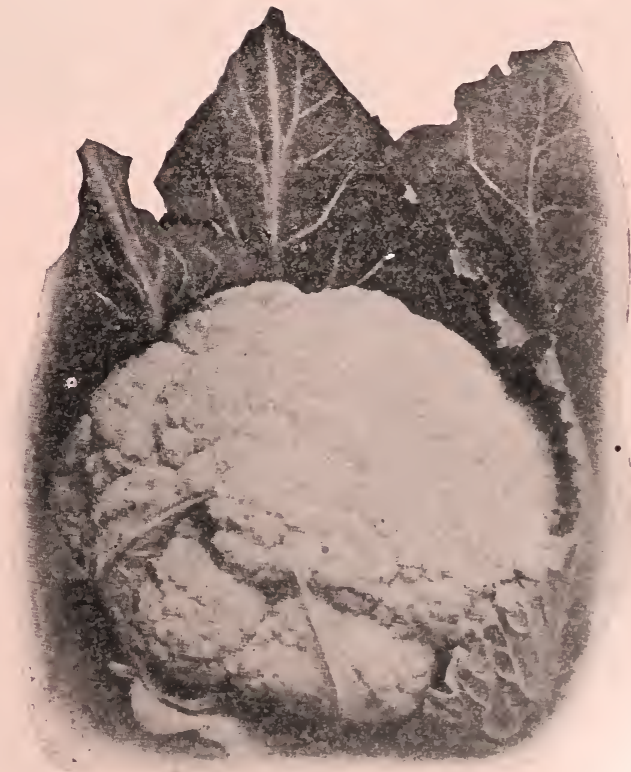

Early Snowball Cauliflower 


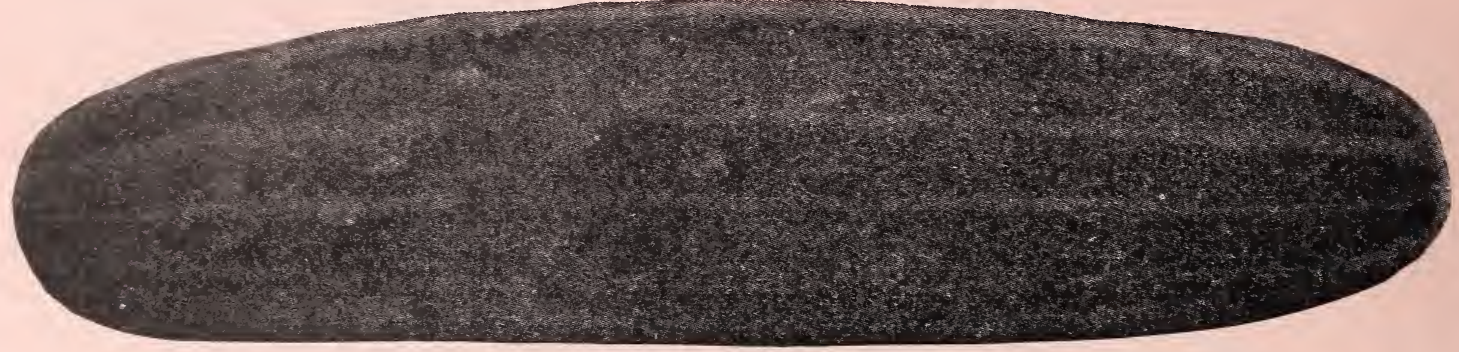

Longfellow Cucumber

The LONGFELLOW is a White Spine type of dark green appearance. The vines are exceptionally productive, with fruits averaging 12 to 14 inches in lenngth by $2 \frac{1}{2}$ inches in diameter. This variety retains its dark color when shipped to distant markets, thereby pleasing both the market gardener who is the shipper and the dealer who is the receiver. Also an ideal type for the private garden.

Pkt. 10 c; oz. 20 c; $1 / 4$ tb 90 c; ib $\$ 2.50$

WONDERFUL CELERY-Also known as Golden Plume. This new variety of Celery is rightly named wonderful. It is a distinct, new and valuable early variety of Celery. The plants are semidwarf and very vigorous, growing to an unusually large size. It has a very full heart of beautiful yellow color and bleaches very quickly. It is fast replacing the older types of Golden SelfBlanching in all the leading growing sections.

Its vigorous growth makes it very free from blight and other celery diseases.

The eating quality of this celery is the finest and it stands way ahead of any of the early easy bleaching types of Celery.

Pkt., 25c; oz., $\$ 3.00 ; 1 / 4$ lb., $\$ 8.00$; lb., $\$ 20$.

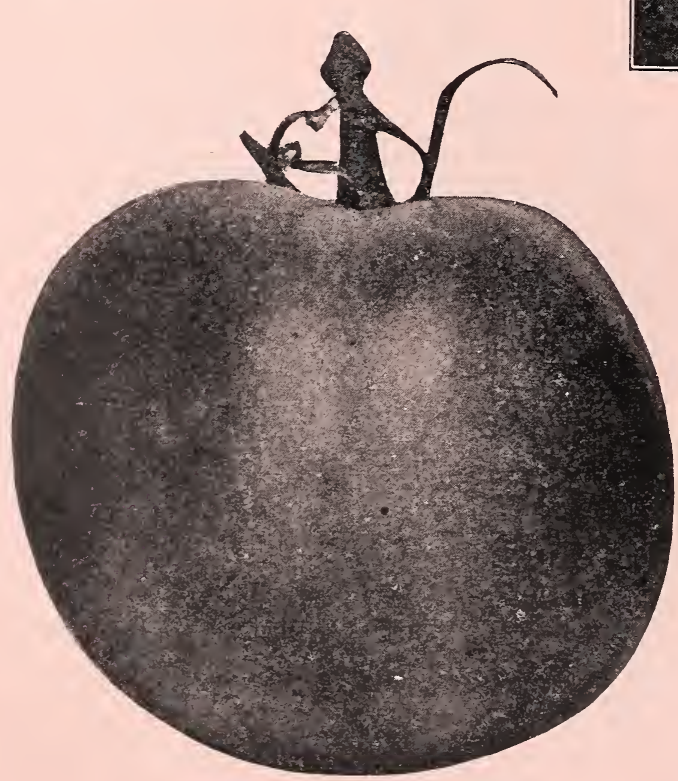

Marglobe Tomato

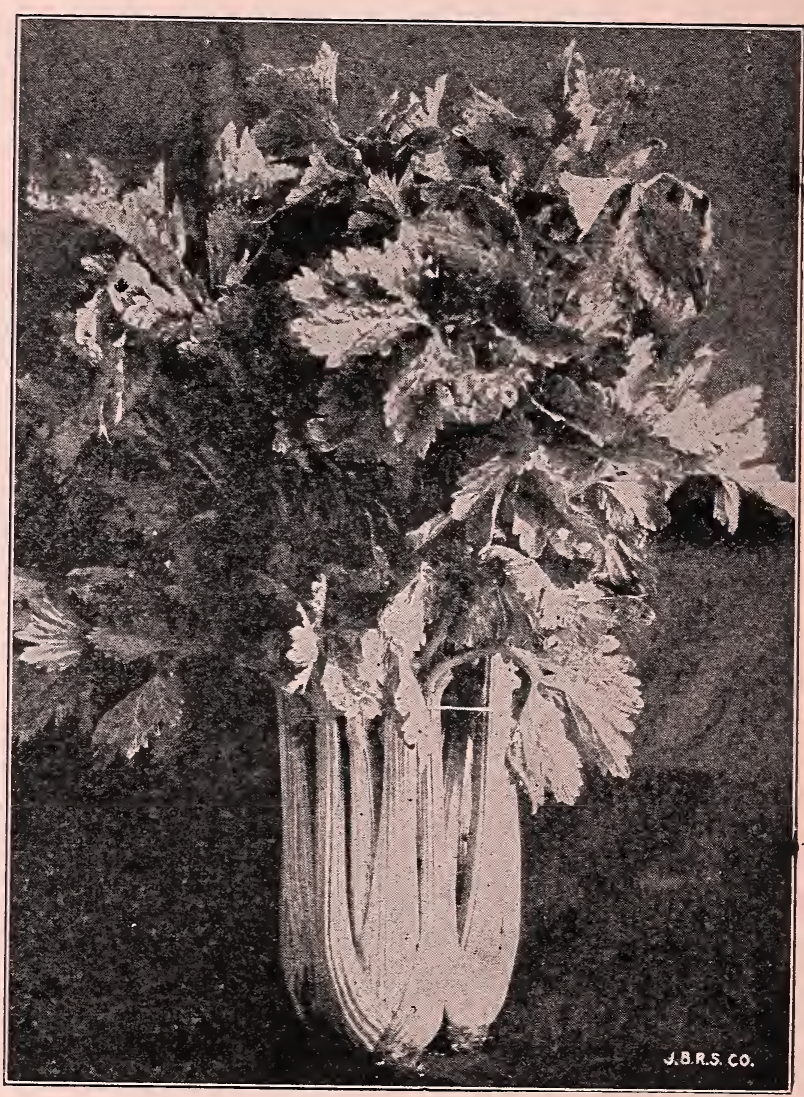

Wonderful Celery

MARGLOBE TOMATO.-This Great New Tomato introduced by the U. S. Dept. of Agriculture through the efforts of Dr. Fred J. Pritchard, of the Bureau of Plant Industry is the last word in Tomatoes.

Its fine annearance, great productiveness, deep globe shape and superb table qualities is giving it first place wherever known. Its spreading habits of growth enable it to bear large perfect globe-shaped fruit in great abundance. In color it is a most beautiful scarlet, ripening well $u$ to the stem. In the south, where there is danger of nail-head rust, "The Marglobe" has proven resistant to the disease, and is being planted almost exclusively to all others.

Pkt. $25 \mathrm{c}$; oz. $75 \mathrm{c} ; 1 / 4$ tb $\$ 2.75$; ib $\$ 8.00$. 


\section{S P E C I A L T I E S}

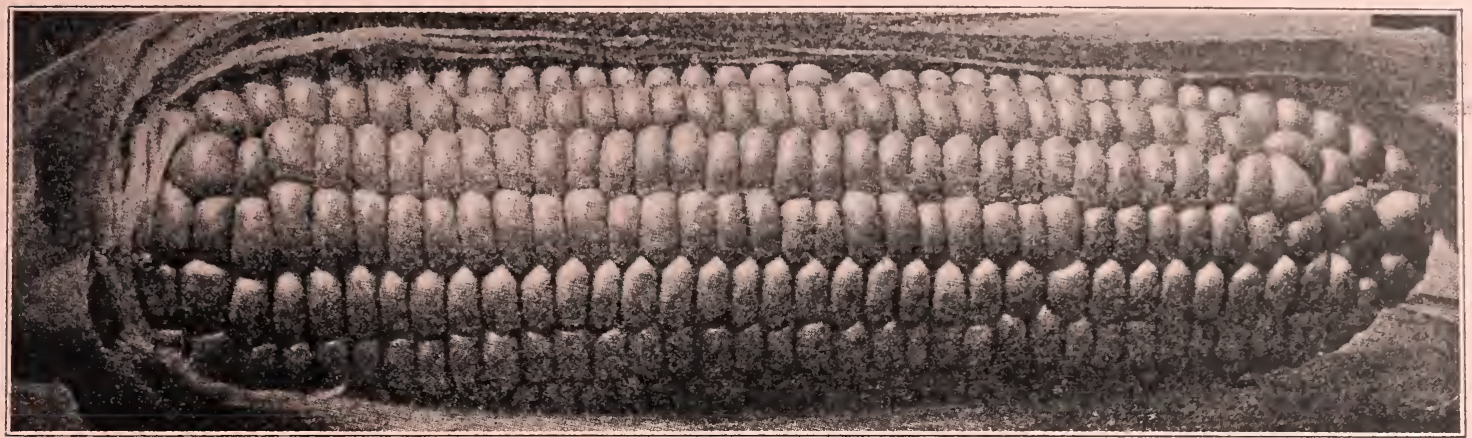

Woodruff's Extra Early Yellow-The New Wonder Sweet Corn

-This is truly a wonder variety of Sweet Corn, being 13 days earlier than Golden Bantam. In fact, this variety will be off the market before the Golden Bantam is ready. From a gardener's viewpoint it is the most valuable introduction in recent years. The ears are larger in size than the Bantam, 12 rowed instead of 8 , and of equally good color.

Its Ears Are Fully 61/2 Inches Long

This new corn was introduced by Dr. Yeager of the North Dakota Experimental Station. We firmly believe that Golden Sunshine will eventually displace Golden Bantam.

Pkt. 25c; qt. 70c; pk. $\$ 4.00$; bu. $\$ 15.00$.

\section{GOLDEN SUNSHINE SWEET CORN}

Golden Sunshine Sweet Corn has become a standard, having a really large ear and two weeks earlier in maturity than Golden Bantam. We have had many favorable comments on this variety for the past few years and we strongly recommend it as a standard moneymaker, being one of the BEST of its class for a PURE GOLDEN YELLOW SWEET CORN.

Pkt., 25c; qt., 70c; pk., $\$ 4.00$; bu., $\$ 15.00$.

NEW YORK OR WONDERFUL LETTUCE -An Excellent Stock of the Iceberg Type. More N. Y. Lettuce is grown in the U. S. than all other varieties combined. Its first great success was made in the Imperial Valley of California, and since that time it has spread over the entire country. Over 20,000 carloads are shipped from the Western States yearly. It is now grown in many market gardens in the East.

Pkt., 10c; oz., 25c; 1/4 lb., 85c; lb., $\$ 3.00$.

\section{BIG BOSTON LETTUCE}

S. D. Woodruff \& Sons' Select Strain-We believe that this is the surest heading, most solid, and most uniform strain of Big Boston Lettuce ever produced. It forms a very large frame and unlike most bulky Lettuces, it heads quickly and is extremely hard. For Spring and Fall use it has no superior. On account of its hardness and the tough charac-

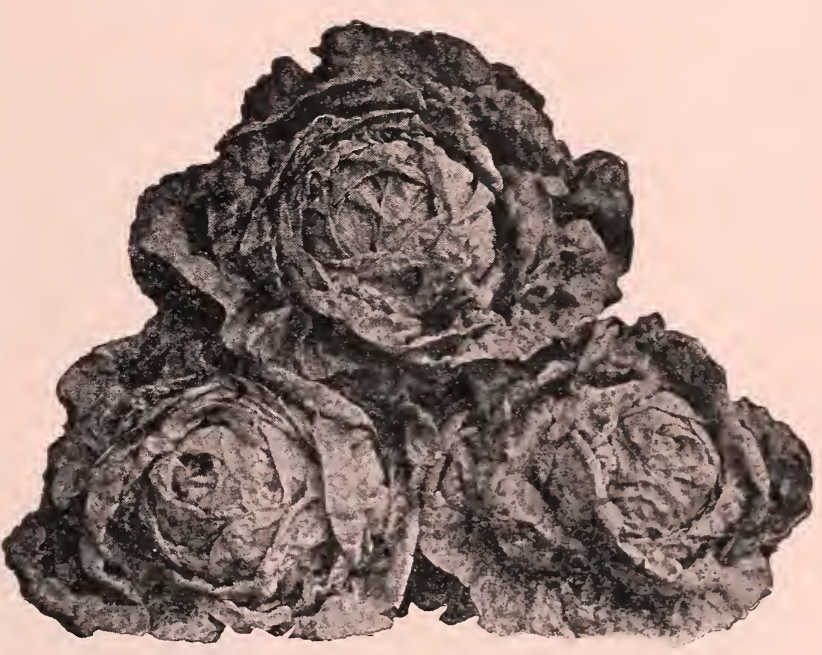

New York or Wonderful Lettuce

ter of the outer leaves, it cannot be surpassed for a shipping Lettuce.

Pkt., 10c; oz., 20c; 1/4 İb., 75c; lb., $\$ 1.50$.

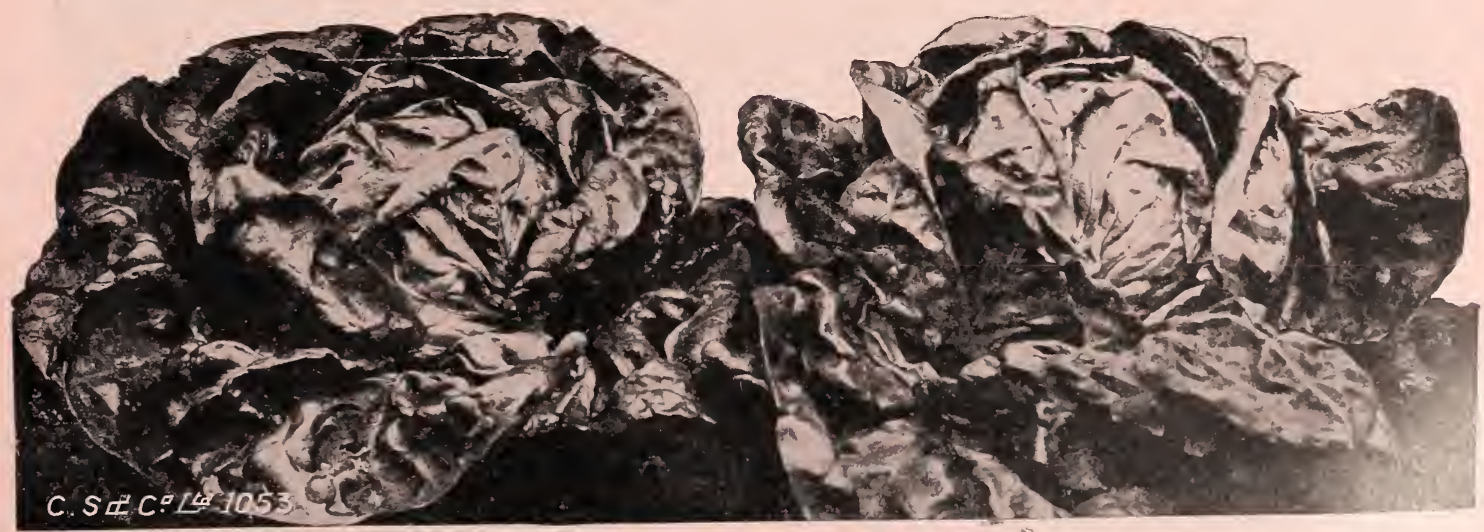

Big Boston Lettuce, Woodruff's Select Strain 


\section{S P E I A L T IES}

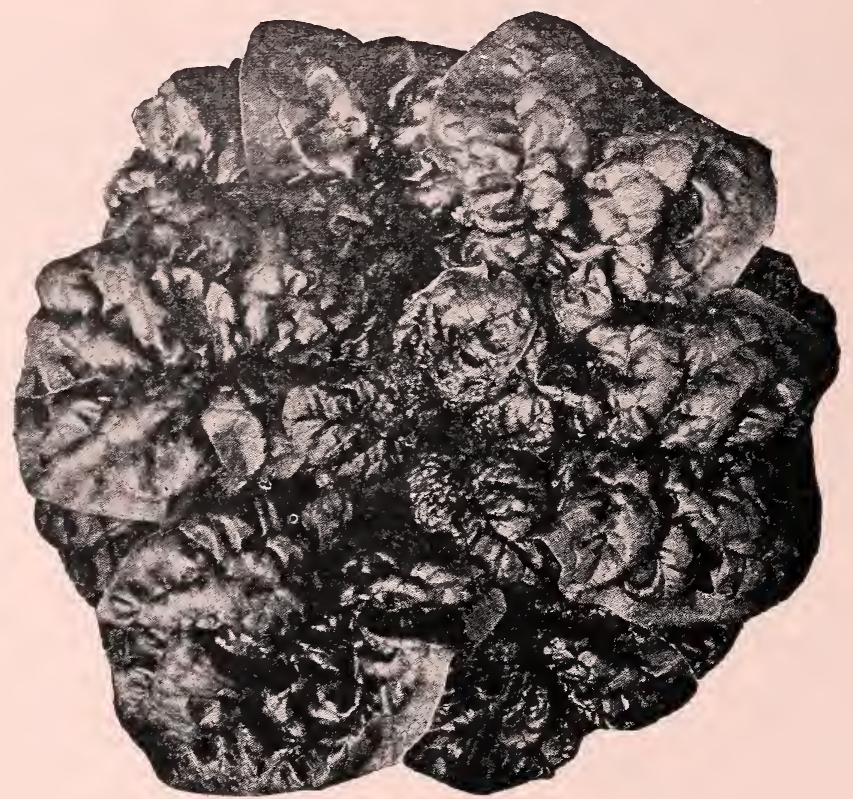

WOODRUFF'S NEW L O N G STANDING SAVOY SPINACH

Shows a marked improvement over the old Standard Bloomsdale Savoy type. It is very heavily curled. It is a tremendous yielder and is a deep dark green color. It will stand two weeks longer without shooting seed stalks than Bloomsdale, which is a really remarkable variety.

It is a wonderful hot weather Spinach and some catalogues this year will feature it under that name. Do not hesitate to use this instead of the old types of Bloomsdale Savoy-it will pay you.

Oz. $10 \mathrm{c} ; 1 / 4$ tb $15 \mathrm{c} ;$ ib $40 \mathrm{c} ; 100$ tb $\$ 25.00$.

New Long Standing Savoy Spinach

\section{WOODRUFF'S NEW GIANT STRAIGHT NECK SQUASH is a selection from the standard Giant Summer Crookneck and a real im- provement on this sort. \\ Pkt. 10c; oz. $35 \mathrm{c} ; 1 / 4$ lo $\$ 1.00$ tb $\$ 2.50$.}

\section{Copenhagen Market Cabbage}

E $x$ t $x$ a SpecialBred Danish Grown Seed. The large round-headed cabbage. The heads are exceptionally large for so early a variety, very solid and of ..most excellent quality. The plants are vigorous $\mathrm{but}$ compact, with short stem and few outer leaves, which are of rather upright growth. Our strain produces the characteristic large, round heads that for solidit $y$ and excellent quality make this variety so valuable. Our strain has been carefully bred for earliness and uniformity of maturity.

Prices-Pkt. 10c; oz. $50 \mathrm{c} ; 1 / 4$ tb $\$ 1.50$, $1 \mathrm{tb} \$ 4.50 ; 5$ Ib $\$ 15.00$, postpaid.

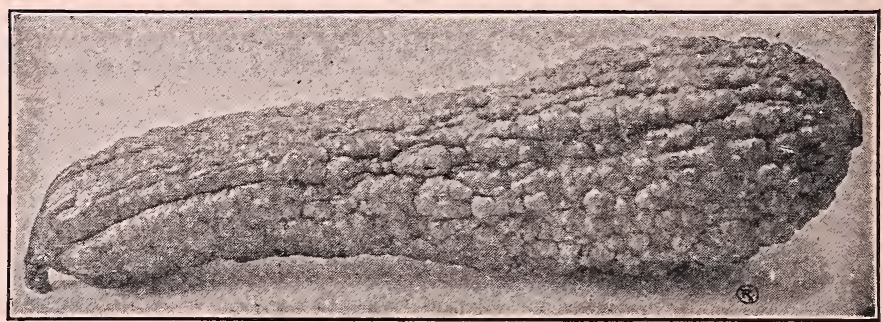

Woodruff's New Giant Straight Neck Squash

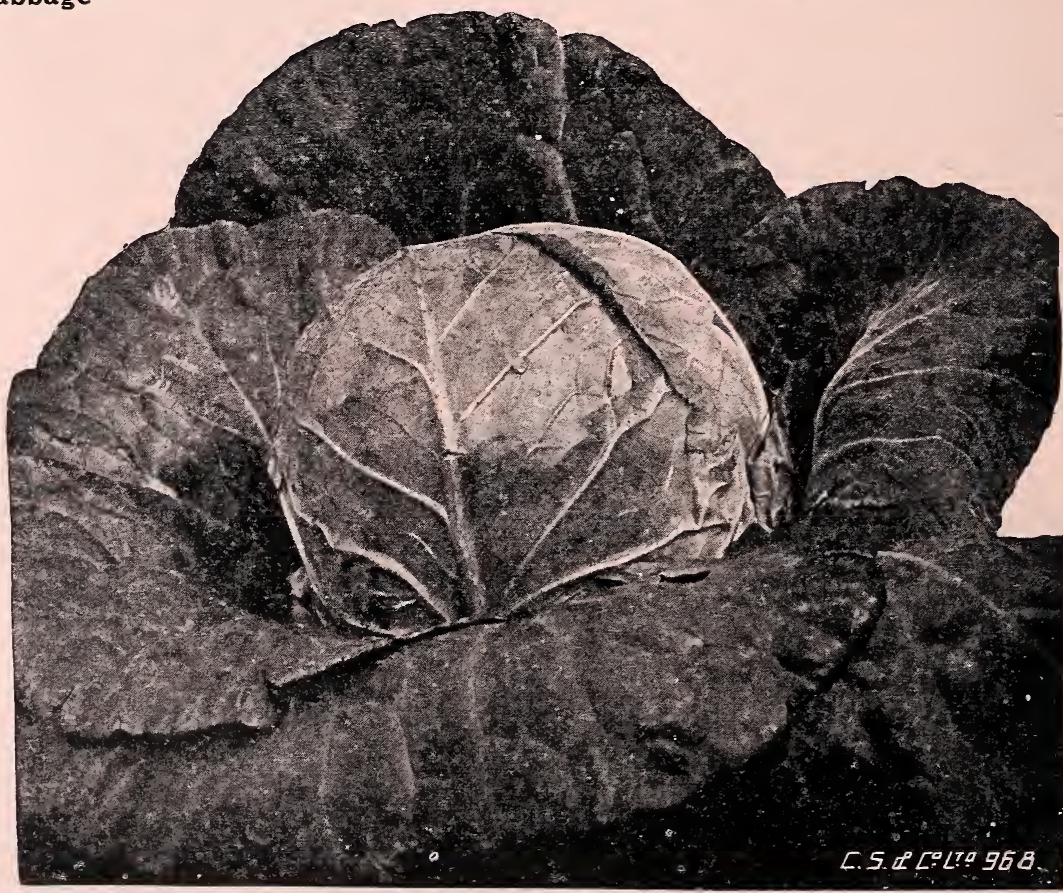

Copenhagen Market Cabbage 


\section{SPECIALTIES}

S. D. WOODRUFF'S \& SONS' SPECIAL STRAIN BLACK VALENTINE.-This strain will be found exceedingly valuable to market gardeners and especially those who are located a distance from market. A good shipper and an enormous yielder.

Extra long, round, straight and tender soft green colored pods.

This strain has been developed to meet market gardeners requirements. The supply is limited-get your order in early.

Pkt., 15c; lb., 40c; 100 lbs., $\$ 25.00$.

BOUNTIFUL BEANS-This is far and away the best Flat Podded Green Bean grown. The pods are six to seven inches long - thick, flat and slightly curved. Stringless and with little fibre. It is the most popular Green Bean on the market today and it has come to the point where more Bountifuls are used than all other Green Beans put together.

Pkt. 15c; tb $40 \mathrm{c} ; 100$ lb $\$ 32.00$.

RADISH, SELECT SCARLET GLOBE-Our strain of this, the most popular of all market sorts, is grown from selected hand transplanted roots and produces a beautiful uniform color and shape.

Pkt., 10c; oz., 15c; 1/4 lb., 30c; lb., 75c; 10 lbs., 70c lb.; 50 lbs., 65c lb.

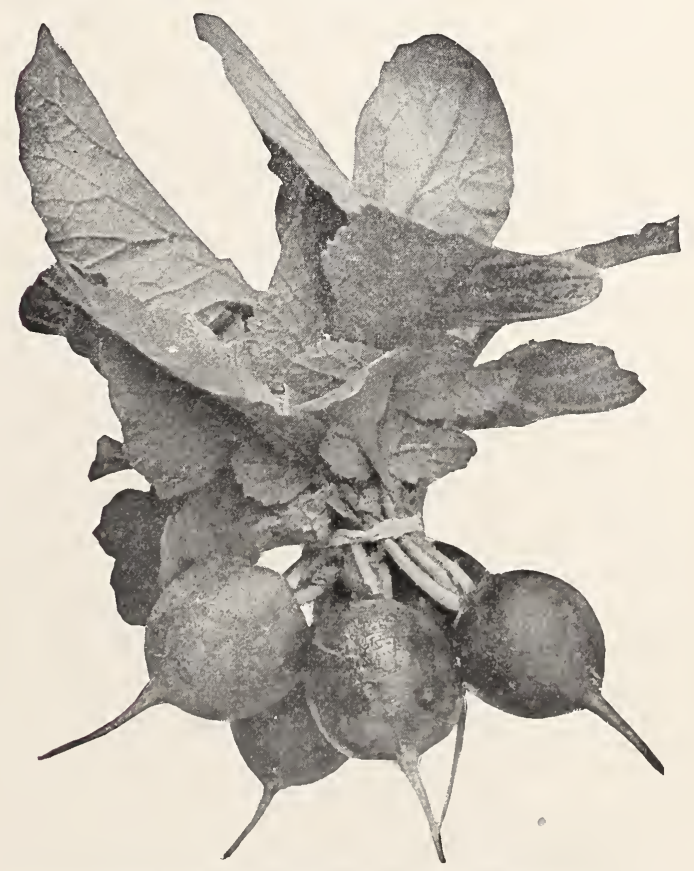

Woodruff's Selected Scarlet Globe Radish

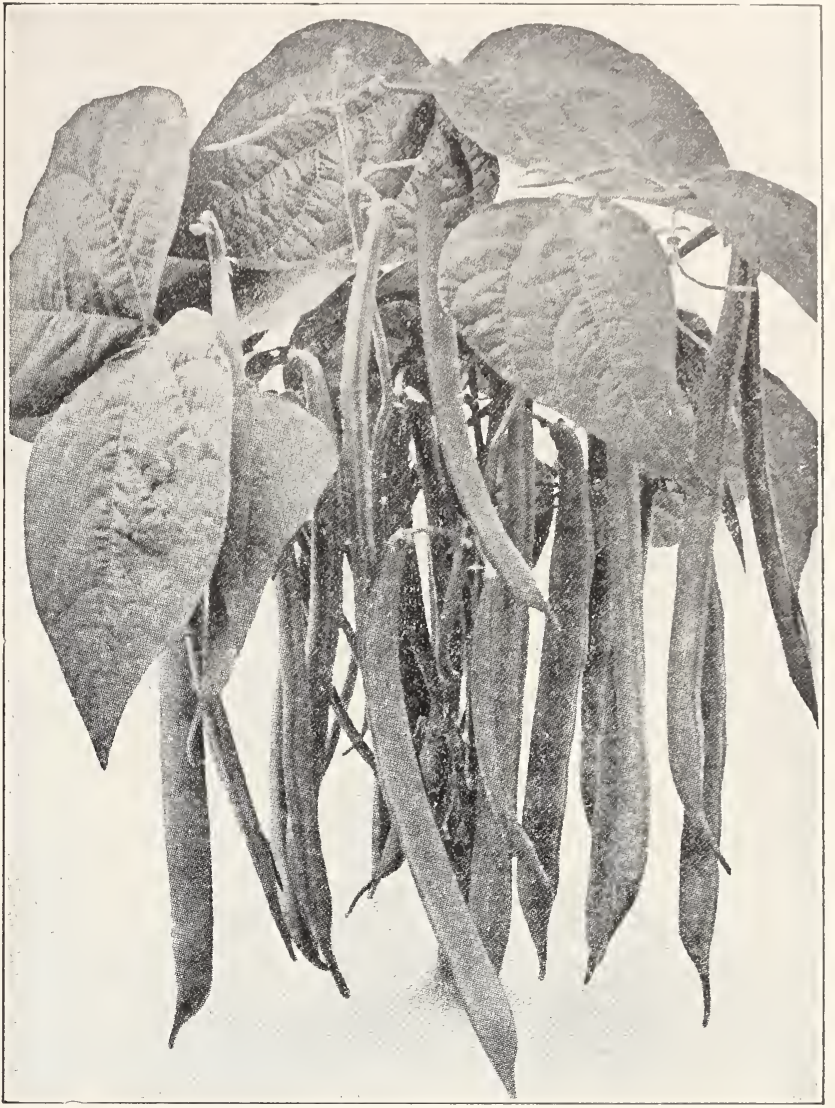

Black Valentine Beans

BROCCOLI-Special Italian CalabreseThe right kind. Broccoli is recognized everywhere as a delicious vegetable and is in very great demand. It grows like Cauliflower, and, is cooked and served in a similar way.

Good growers should not overlook this new and delicious vegetable_-it will be a money maker.

Sow in frames for spring crop; June and July for fall crop. Time required for maturity of crop from 90 to 125 days, according to weather conditions.

Pkt., 15c; oz., $\$ 2.00 ; 1 / 4$ lb., $\$ 5.00 ; 1 b .$, $\$ 15.00$.

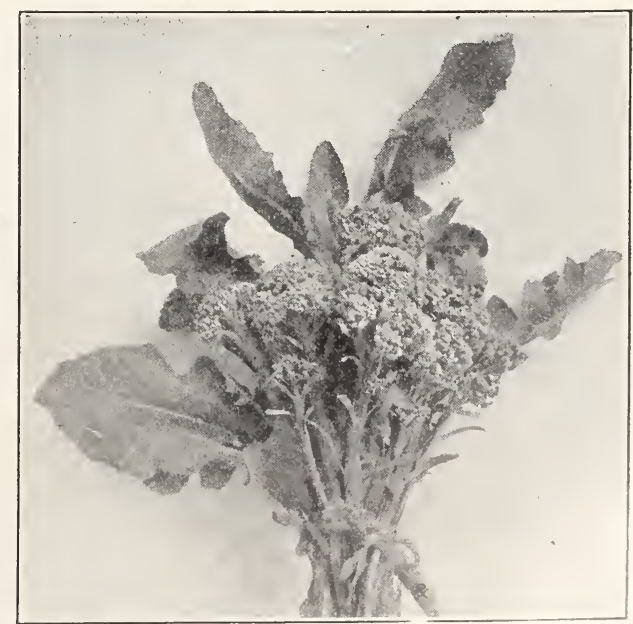

Calabrese Broccoli 


\section{ASPARAGUS ROOTS}

(All 2-year--old strong roots)

\begin{tabular}{|c|c|c|}
\hline & Per & Per \\
\hline & 100 & 1000 \\
\hline Palmetto & $\$ 1.50$ & $\$ 12.00$ \\
\hline Mary Washington ...................... & 1.50 & 12.00 \\
\hline Martha Washington ................. & 1.50 & 12.00 \\
\hline Giant Argenteuil & 1.50 & 12.00 \\
\hline
\end{tabular}

Special prices on large lots.

\section{ASPARAGUS SEED}

Pkt. $10 \mathrm{c}$; oz. $20 \mathrm{c} ; 1 / 4$ th $40 \mathrm{c} ; 10$ th or over 10c per tb less.

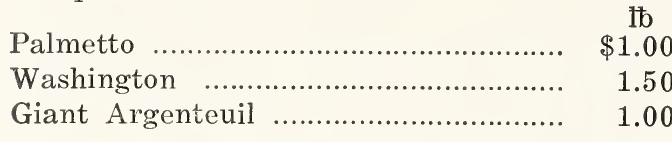

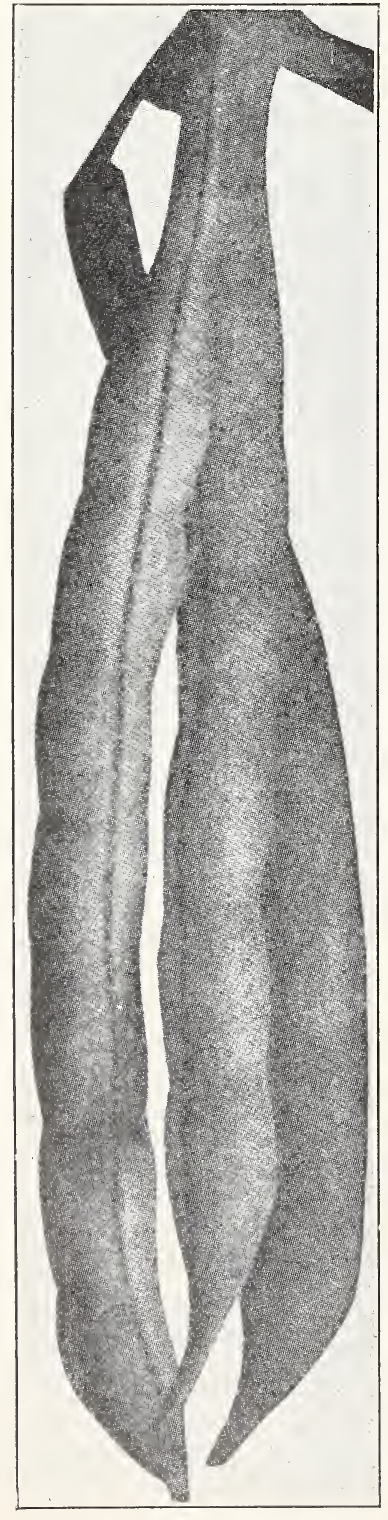

Giant Stringless

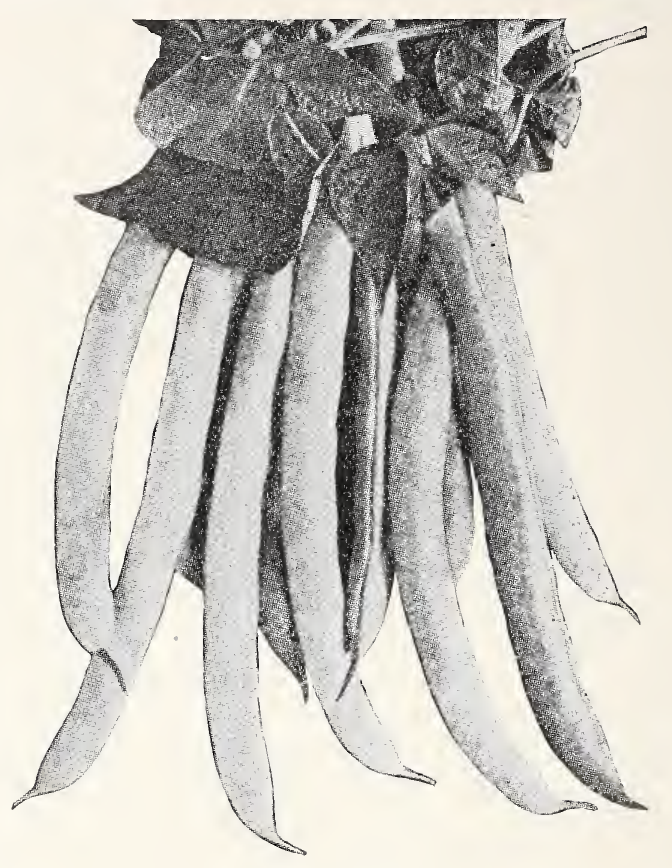

Bountiful Stringless

\section{BEANS, DWARF, GREEN-PODDED VARIETIES}

FULL MEASURE-The best second early round podded sort of recent introduction. The pods are long, bright green, entirely stringless, and slightly irregular in shape. Very prolific and of excellent quality.

Pkt. 20c; tb 50c; 10 tb $\$ 4.50 ; 100$ tb $\$ 40.00$.

Packets of all following varieties $15 \mathrm{c}$

GIANT STRINGLESS GREEN POD-Extra

ib 100 tb

Early. Exceptionally prolific; long, round straight, thick pods, absolutely free from strings

BLACK VALENTINE-An excellent ship-

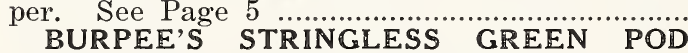
- Extra early, stringless round pods ................

BOUNTIFUL-Unusually fine, flat podded, practically stringless

DWARF HORTICULTURAL-Round pod shell bean; medium length;

EARLY RED VALENTINE - Improved round pod, slightly curved, light green color, rapid grower and abundant producer ............

STRINGLESS REFUGEE-Same as 1,000-1,

but stringless ........................................ variety; best for canning .............................

LONGFELLOW - A new early and prolific, long round pod

FRENCH STRAIN DWARF HORTICULTURAL_Finest of all shell beans. Highly colored long pods

LOWE'S CHAMPION BUSH - Very flat pod; stringless. (Italian: Frigole Roda Gene) WHITE KIDNEY - Fine quality, used shell-

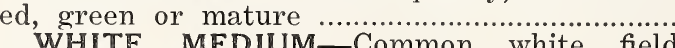
WHITE MEDIUM-Common white field RED KIDNEY-A popular shell bean in the WHITE BOSTON-Smaller than White Medium, more prolific, better quality................ WHITE MARROWFAT-Large vines, short runners; when dry, beans nearly round ........ NOTE-60 lbs. of Beans Per Bu.

$\$ .40 \quad \$ 30.00$

$.40 \quad 25.00$

$.40 \quad 30.00$

$.40 \quad 32.00$

$.40 \quad 25.00$

$.40 \quad 25.00$

$.50 \quad 40.00$

$.40 \quad 25.00$

$.40 \quad 25.00$ 


\section{DWARF WAX PODDED BEANS}

Packets all varieties $15 \mathrm{c}$.

HODSON WAX - The largest flat podded and surest rust-proof wax bean; quite late

W EBBER or CRACKERJACK

WAX - A new wax Bean. Pods are of an exceedingly bright yellow color. Extra early, very prolific and hardy

BURPEE'S NEW KIDNEY WAX - Hardier and more prolific than the popular Wardwell's, with even handsomer pods of better quality

STRINGLESS REFUGEE WAXPerfect Refugee with round curved stringless wax pods

DAVIS WHITE KIDNEY WAX-

Pods long, flat; color light yellow. Most prolific and largest podded wax Bean

WARDWELL'S KIDNEY WAXOne of the best large podded wax Beans; hardy, heavy cropper. Broad, long, flat pods

PENCIL POD BLACK WAX Round pods, very early and productive, stringless

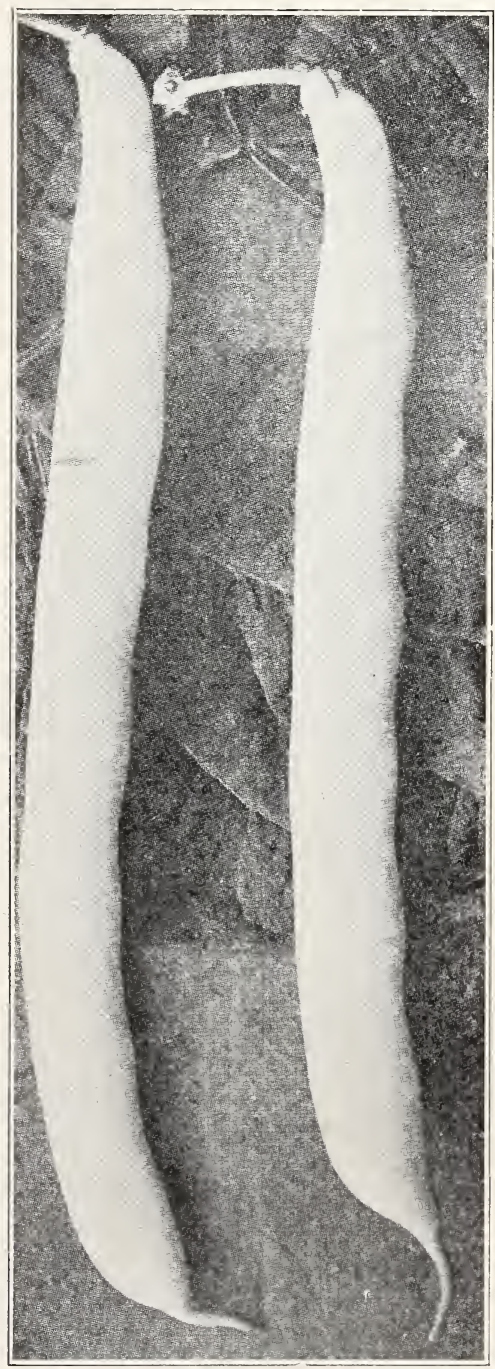

Sure Crop or Bountiful Wax (Stringless)

\section{th $100 \mathrm{tb}$}

$\$ .40 \$ 25.00$

25.00

35.00

30.00

25.00

25.00

.40

25.00

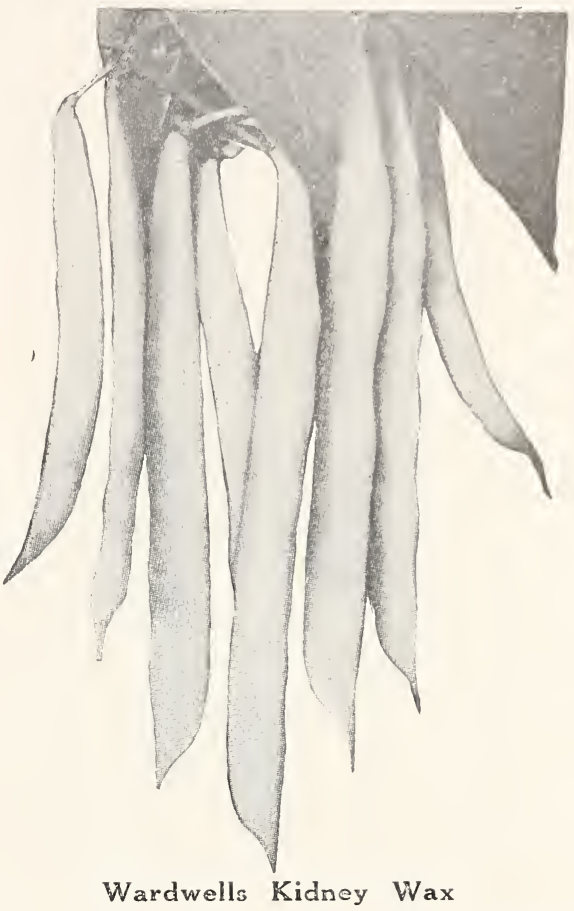

tb $100 \mathrm{tb}$

CURRIE'S RUST-PROOF WAXThe earliest, and one of the most prolific of the flat pod wax beans.

GOLDEN EYE WAX-An early, vigorous variety, flat-podded, rustproof

ROUND POD KIDNEY or BRIT

TLE WAX -One of the best round podded varieties

PROLIFIC BLACK WAX - Old standard sort, early. Pods round ....

IMPROVED GOLDEN WAX Pods semi-round and rust-proof. Most popular wax variety

UNRIVALLED WAX - An immensely productive, first early showy sort. Pods perfectly straight, somewhat flattened but fleshy.......

SURE CROP WAX or BOUNTI. FUL WAX-(Black Seed)

\section{POLE OR RUNNING BEANS}

DUTCH CASE KNIFE-Pods very long, flat, green, seed white

OLD HOMESTEAD or KENTUCKY WONDER-The finest pole bean; pods long, green, round; excellent snap bean; yellow seeded .

LAZY WIFE-Excellent for snap or shell bean; seed white ..................

HORTICULTURAL CRANBERRY, or WREN'S EGG - A showy and excellent variety as a snap or shell bean

MAMMOTH CARMINE PODDED POLE or WORCESTER POLE - A fine shell bean; mammoth size pods

DREER'S EARLY GOLDEN CLUSTER WAX - The best wax pole bean; pods 8 inches long, of golden yellow

tb 100 tb

$.40 \quad 23.00$

23.00 


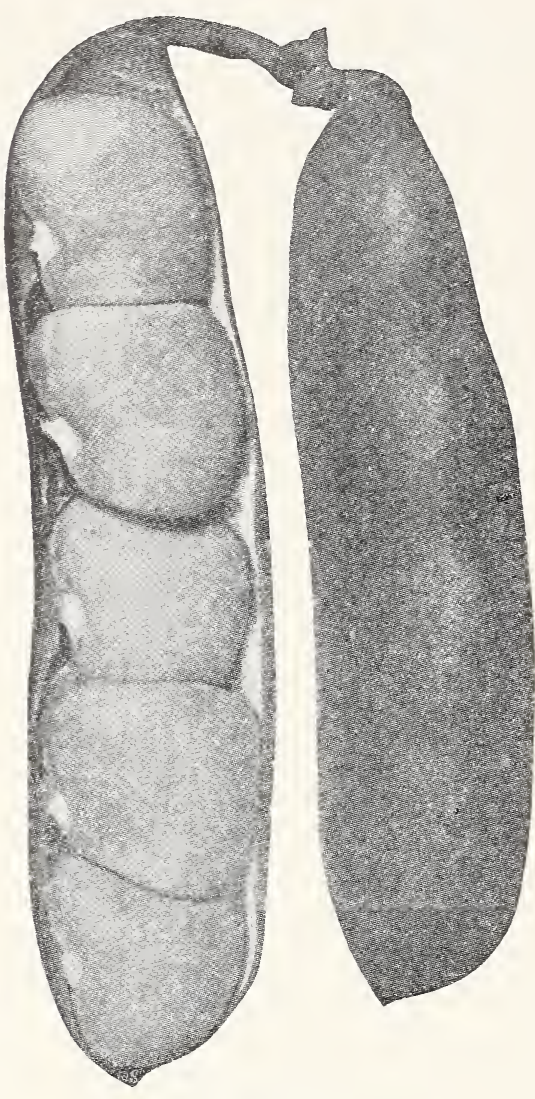

Fordhook Bush Limas

\section{BUSH LIMA BEANS FORDHOOK BUSH LIMA}

is altogether unique and has created the greatest sensation of any vegetable ever produced. Pods are plump. well filled, and twice as large as those of Dreer's Bush.

Pkt. 20c; tb $60 \mathrm{c} ; 100$ tb $\$ 30.00$.

\section{BURPEE'S IMPROVED BUSH LIMA}

is a distinct new creation. It produces a magnificent crop of pods 5 to 6 inches long by $1 \frac{1 / 4}{4}$ inches wide. Pkt. 20c; tb $60 \mathrm{c} ; 100$ tb $\$ 30.00$.

WOODRUFF'S LIMA BEANS

ARE THE STANDARD FOR QUALITY

AND GERMINATION. We sell Annually

Carloads of LIMA BEANS FOR SEED, Both Pole and Bush Varieties

HENDERSON'S BUSH LIMA

Pkt. $\quad$ tb $100 \mathrm{lb}$

-Beans smaller than Burpee's or Dreer's, but very early and productive. Called Baby Lima. Earliest and best canning variety

WOOD'S PROLIFIC BUSHThe early Sieva or Butter Bean of the South, very productive BURPEE'S BUSH - Beans large as the white pole lima beans; perfect dwarf and very productive

\section{POLE LIMA BEANS}

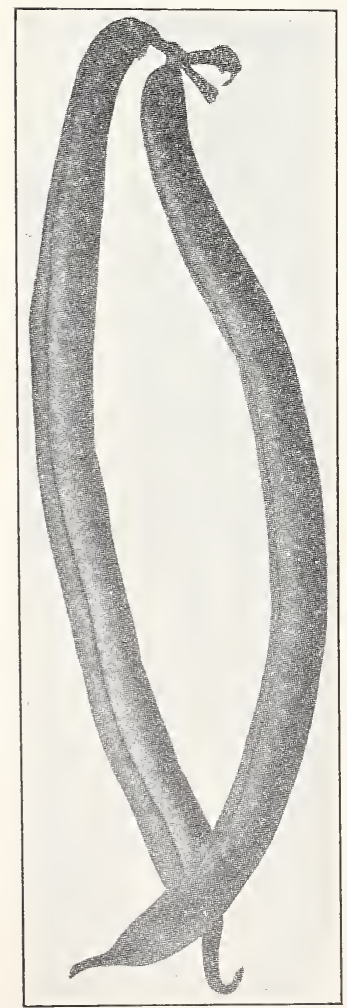

Pkt., 20c; lb., 40c; 100 lbs., $\$ 22.00$ All Sorts

Siebert's Early Lima.

Extra Large White Lima.

King of the Garden.

Early Jersey.

Ford's Mammoth. Immense pods.

Early Leviathan. Early, very prolific.

Challenger or Potato Lima.

Burpee's Giant Podded. Immense yielder.

Sieva or Carolina Pole. Small seeded.

Scarlet Runner. Grown especially for orna-

ment.

BROCCOLI or ITALIAN CAULIFLOWERGreen Heading Calabrese-The head is cut and smaller heads grow out from main stalk-See Page 5.

Plkt., 15c; oz., $\$ 2.00$; 1/4 lb., $\$ 5.00$; lb., $\$ 15.00$

BRUSSELLS SPROUTS-Selected Long Island Dwarf-

Pkt. $10 \mathrm{c}$; oz. $50 \mathrm{c} ; 1 / 4$ ib $\$ 1.50$; it $\$ 5.00$.

Kentucky Wonder Pole
$\$ .20 \quad \$ .40 \quad \$ 20.00$

$.20 \quad .50 \quad 20.00$

$.20 \quad .50 \quad 22.00$

$\begin{array}{rrrr}\$ .20 & \$ .40 & \$ 20.00 \\ .20 & .50 & 20.00 \\ .20 & .50 & 22.00\end{array}$

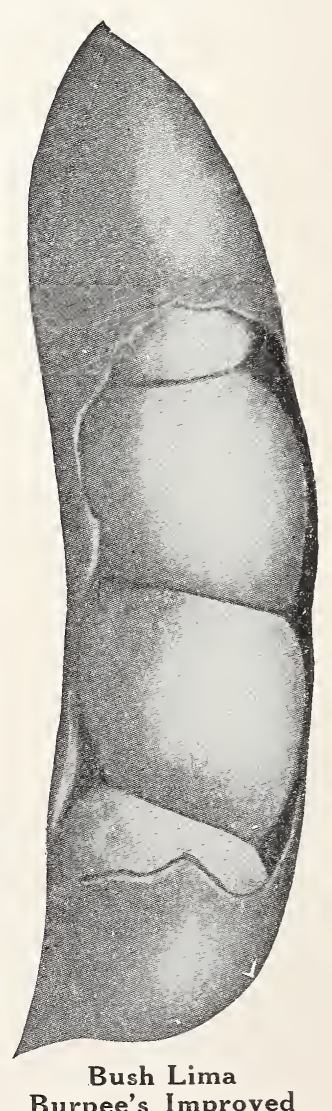




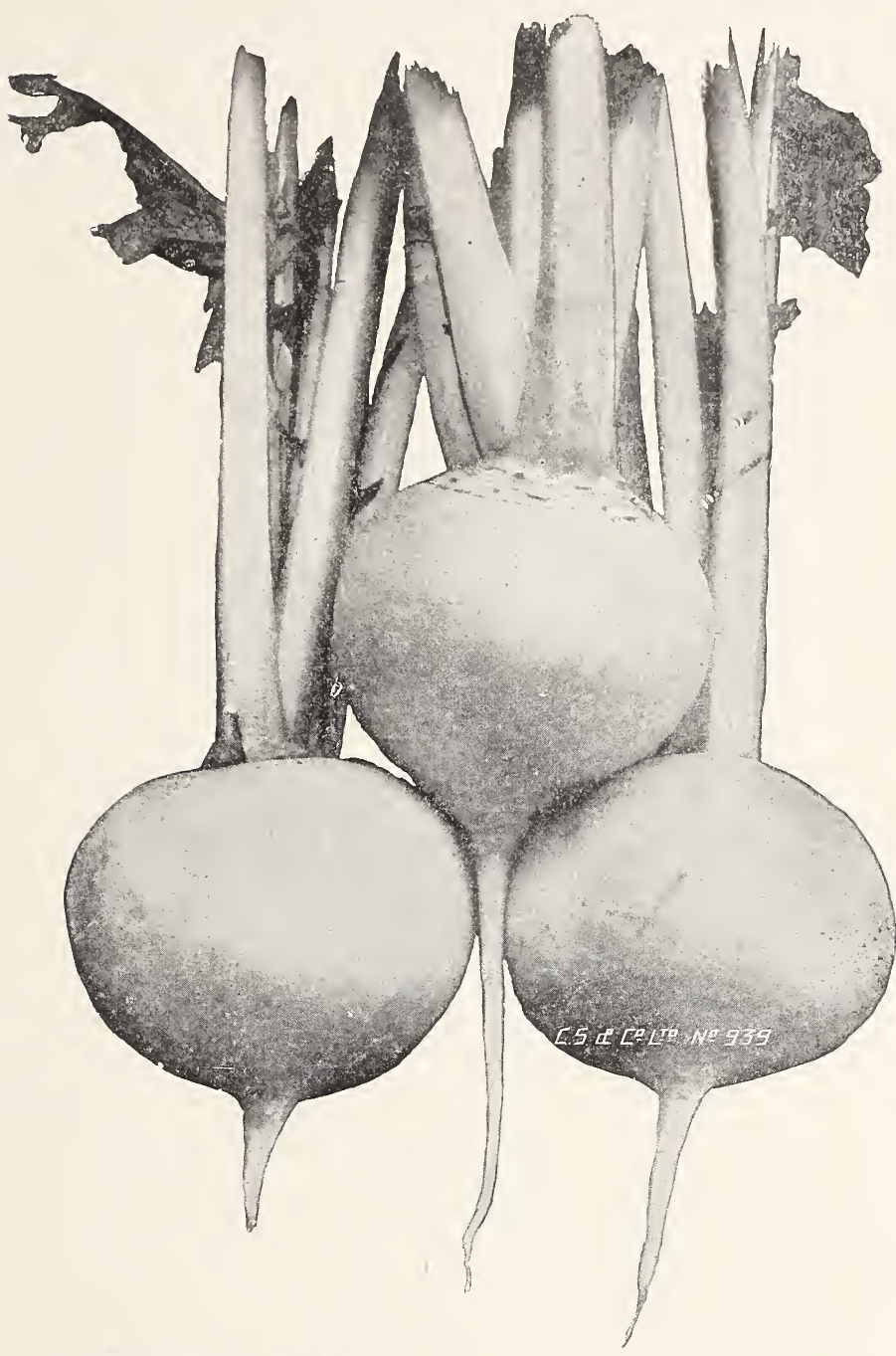

SWISS CHARD

Grown for its numerous, fleshy, tender leaves and stalks which are excellent for greens.

Lucullus-Has broad, undulated leaves of attractive yellowish green color and very large, broad, white stalks and midribs which may be cooked and eaten like asparagus.

Green Broad Ribbed - Like the above, excepting that the midrib stalk has been eliminated. Used exclusively $\mathrm{f}$ o $\mathrm{r}$ greens. Pkt., 10c; oz., 15c; $1 / 4$ lb., 40c; lb., $\$ 1.00$.

\section{SUGAR BEETS AND MANGEL WURZEL}

We offer the following standard sorts of Mangel Wurzel Seeds, all pure and true to name, at a uniform price as follows: Per oz., 10c; lb., 50c $5 \mathrm{lb}$. lots at $40 \mathrm{c}$.

Mammoth Long Red

Golden Tankard

White French Sugar

Giant Half Sugar Rose

Yellow Globe

Giant Yellow Intermediate

Sludstrup.

\section{"BUY EARLY WONDER BEET"}

Its pretty uniform globe shaped roots with small tap root - Its Dark Red Color-Its magnificent top for bunching-Its earliness-all mark it as preeminently the "Best Beet Grown." Its wonderful top, color and shape make it the finest beet for buyers. Its showy appearance makes it the Best Beet for Growers. We grow the true Original Stock.

\section{Early Wonder Beet}

Pkt., 10c; oz., 20c; $1 / 4$ lb., $40 \mathrm{c} ; 1 \mathrm{~b} ., \$ 1.25$.

The varieties below at uniform prices.

Pkts., 10c; oz., 15c; 1/4 lb., 40c; lb., $\$ 1.00$.

Crosby's Egyptian. Boston strain. A special selected stock.

Extra Early Dark Red Egyptian. Flat, very early.

Eclipse. Round, dark red.

Early Blood Turnip.

\section{DETROIT DARK RED-Our} strain of this splendid main crop Beet is remarkable for its uniform shape, deep-colored flesh and fine, sweet flavor. The roots are globular in shape and have but very small tap roots and are a deep blood-red in color with a dark red flesh.

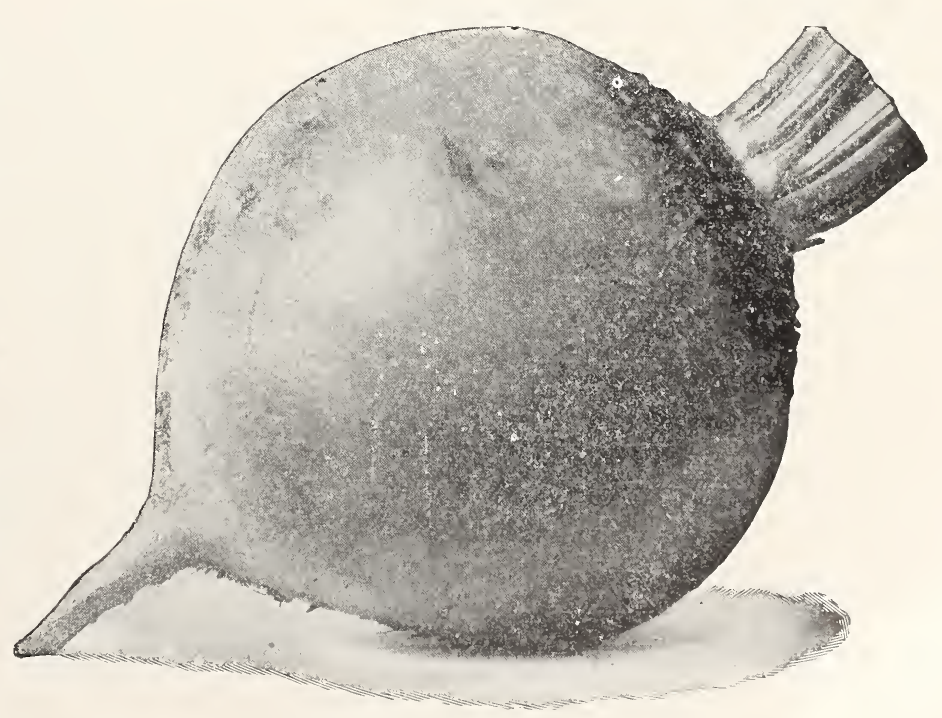




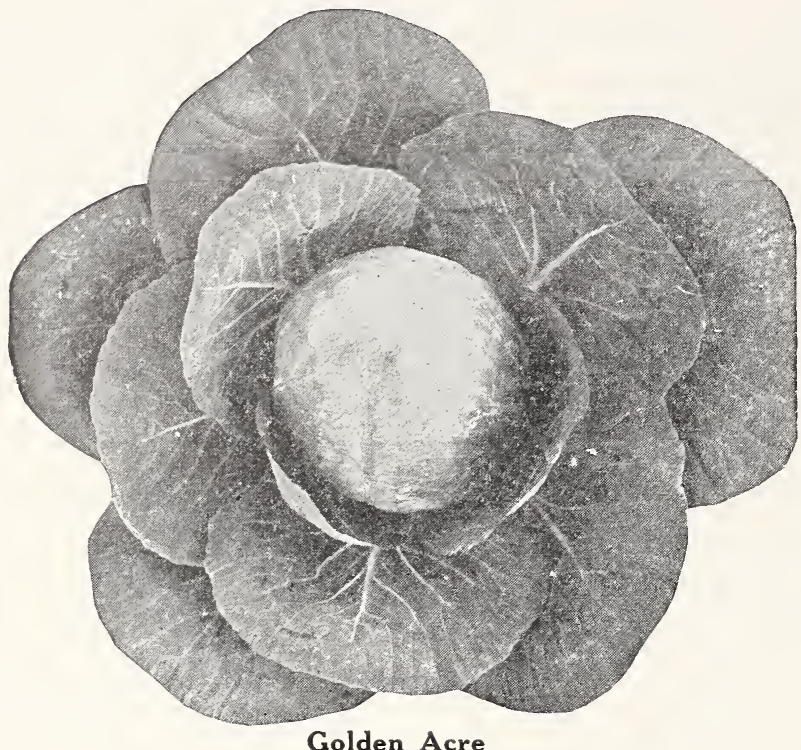

Golden Acre

BUGNER-Very popular through the midwest. Very large semi-round heads which become extremely hard as soon as they begin to form. If planted early is an excellent midsummer as well as fall cabbage. It is thoroughly disease resistant.

Pkt., 10c; oz., 50c; 1/4 lb., \$3.00; lb., \$10.00.

The following Standard Varieties all at uniform prices.

Pkt., $10 \mathrm{c}$; oz., 40c; $1 / 4$ lb., $\$ 1.00 ;$ lb., $\$ 3.50$.

ALL HEAD EARLY - A fine mid-summer or winter variety.

EARLY SUMMER-Splendid second early. Large flat solid heads.

SUCCESSION-A fine general purpose cabbage. Large heads, fine quality for fall or winter.

STEIN'S EARLY FLAT DUTCH - Early fine type Flat Dutch.

PREM. LATE FLAT DUTCH-One of the old large round sorts. Good keeper.

ENKHUIZEN GLORY - A fine $\mathrm{s}$ h o $r \mathrm{t}$ stemmed hard-head variety, fair size and good quality.

\section{SELECTED E ARL Y} JERSEY WAKEFIELD-

Excellent extra early, pointed-head sort. Heads are small as compared with the later Charleston Wakefield but are solid and extremely uniform.

Pkt., $10 \mathrm{c} ;$ oz., $35 \mathrm{c} ; 1 / 4$ lb., $90 \mathrm{c} ; \mathrm{lb} ., \$ 3.50$.

CHARLESTON WAKE FIELD - The heads are large, a nd remarkably $\mathrm{u} \mathrm{n}$ iform in size and shape. Ten days later than $t$ h e Early Jersey Wakefield, but larger size and consequently larger crop. An excellent shipper. Price same as Jersey Wakefield.

\section{CABBAGE}

GOLDEN ACRE - This is a very fine early variety with well formed round heads similar to Copenhagen Market and earlier than Jersey Wakefield. The heads are very firm, bright green in color and have the appearance of being all cast in the same mold. Pkt., 10c; oz., 50c; $1 / 4 \mathrm{lb}$., $\$ 1.75$; lb., $\$ 5.00$.

COPENHAGEN MARKET - See Page 4. (Special Stock.)

In our opinion, after years of experience with various strains of Cabbage seed, this is the finest type of Cabbage, both for early spring and late fall plantings. It will form solid and compact heads of good size earlier than any other variety or strain of Cabbage seed. The tonnage per acre is enormous. It is not and uncommon sight to see a field of ours where every plant has produced a head exactly like its neighbor.

Pkt., 10c; oz., 40c; $1 / 4$ lb., $\$ 1.00$; lb., $\$ 4.00$.

DANISH BALL HEAD or HOLLANDER - The best winter keeper. Solid heavy head. Pkt., 10c; oz., 40c; 1/4 lb., $\$ 1.00$; lb., $\$ 3.50$.

DANISH ROUND HEAD (Short Stem)Similar to Ball Head except a shorter stem and á trifle earlier.

Pkt., $10 \mathrm{c} ;$ oz., $40 \mathrm{c} ; 1 / 4$ lb., $\$ 1.00 ;$ lb., $\$ 3.50$.

SPECIAL DRUM HEAD SAVOY-We wish to call special attention to our Selected Stock Savoy Cabbage. It is very curly, with very compact heads. The leaves turn in snug and the entire head retains a fine dark green color with a very crinkley and curly appearance.

Pkt., 10c; oz., 50c; 1/4 lb., $\$ 1.50 ;$ lb., $\$ 5.00$.

SPECIAL MAMMOTH RED ROCK-This stock grown and selected by an old experienced red cabbage grower. The finest of its kind. Very red solid compact heads. 1/4 lb., $\$ 1.50$; lb., $\$ 5.00$.

CHINESE WONG BOK - Produces a nice head and leaves turn pure white upon maturi y.

Pkt., 10c; oz., 40c; 1/4 lb., $\$ 1.00 ;$ lb., $\$ 3.50$.

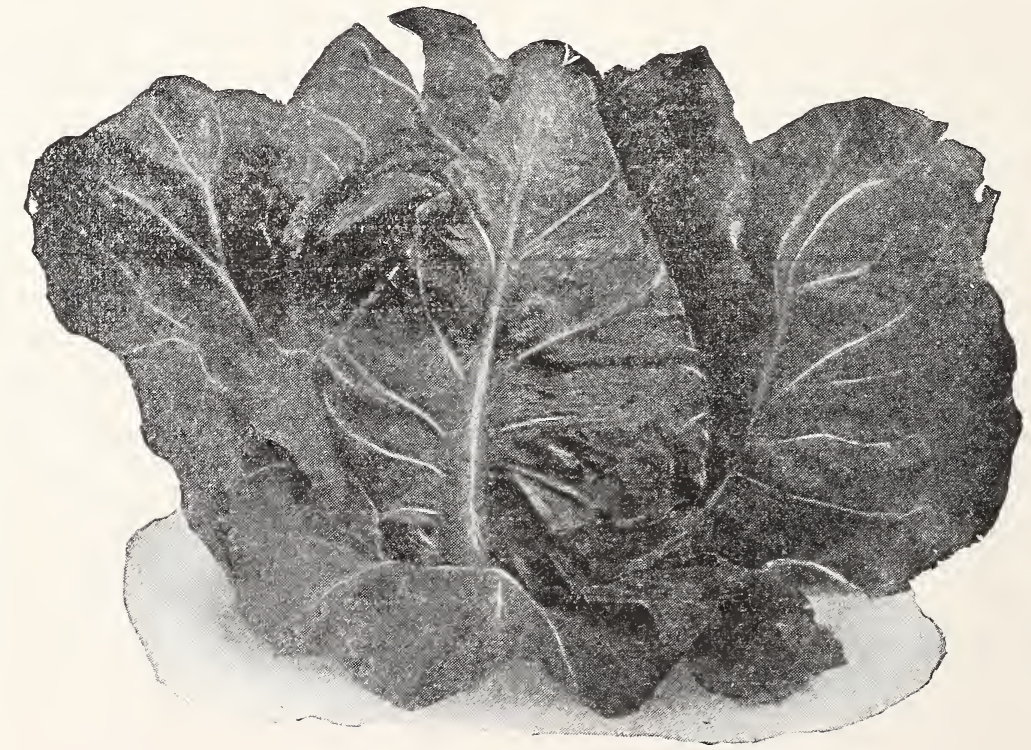




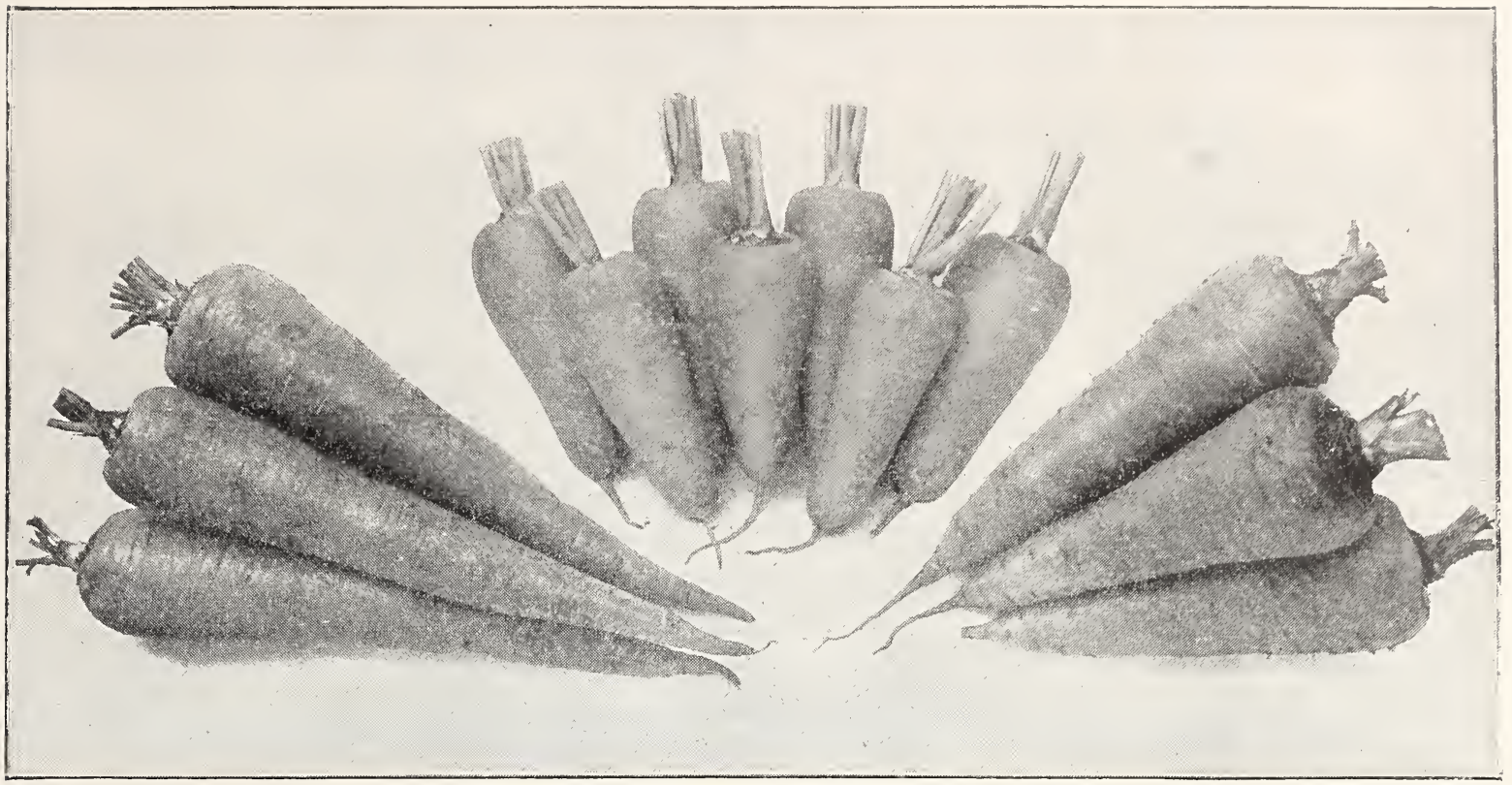

New Long Danvers

Each per pkt., 10c; oz., 25c; 1/4 lb., 50c; except where otherwise quoted.

EARLY SCARLET HORN.

CHANTENAY HALF-LONG

SCARLET NANTES-Stump Rooted....

\section{$\mathrm{Lb}$.}

$\$ 1.25$

1.25

2.00
Chantenay

Danvers Half Long

OXHEART-Great yielder; short and Lb.

thick

DANVERS IMPROVED-Big yielding main crop sort............................. IMPROVED LONG ORA N G E-
$\$ 1.25$

1.25

1.50

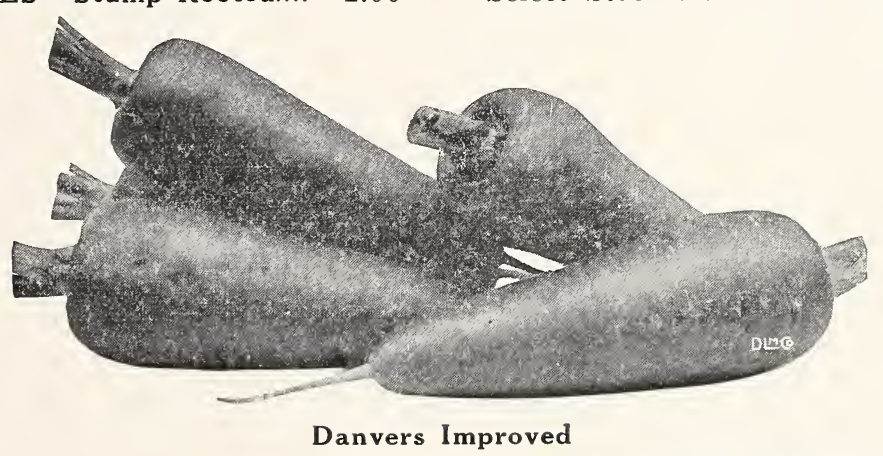

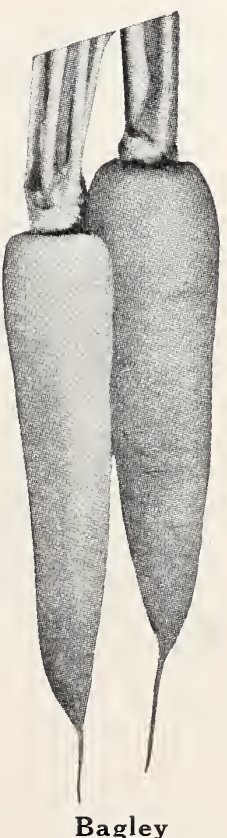

Danvers Improved

\section{CORELESS - (New)}

A half-long, cylindrical, blunt-pointed varie $i \mathrm{y}$, with small tap-root and small, fine top. The shape a n d size are uniform, averaging 6 to 7 inches in $\mathrm{length}, 1 \frac{1 / 2}{2}$ inches in diameter, clean-skinned, smooth, and easily pulled. Pkt., 10c; oz., 25c; 1/4 lb., $75 \mathrm{c} ; 1 \mathrm{lb}$., $\$ 2.00$.

WOODRUFF'S NEW LONG or BAGLEY DANVERS-See Page 1. Pkt., 10c; oz., 30c; 1/4 lb., $\$ 1.00$; lb., $\$ 3.00$.

THE HUTCHINSON - Pkt., $10 \mathrm{c} ;$ oz., $30 \mathrm{c} ; 1 / 4$ lb., $\$ 1.25 ; \mathrm{lb}$, $\$ 5.00$.

WHITE BELGIAN - F o r stock. Pkt., 10c; oz., 20c; $1 / 4$ lb., 35c; lb., $\$ 1.00$.

YELLOW BELGIAN - For stock. Pkt., 10c; oz., 20c; 1/4 lb., 35c; lb., $\$ 1.00$.

CHANTENAY - This splendid carrot belongs to the half-long stump-rooted type, with good girth makes a heavy tonnage yield, also a beautiful shaped carrot for bunching at any time after it has made half its growth.

Pkt., 10c; oz., 15c; 1/4 lb., 40c; lb., \$1.25. 


\section{CAULIFLOWER}

EARLY SNOWBALL-This variety is the standard by which all others are judged. It makes the smoothest and most solid heads. (See page 1.)

It is the earliest maturing strain of shortleaved type. It is one of the most popular of all sorts, both for the market gardener and home use. Our strain of this selected Denmark grown seed can be relied upon as one of the most satisfactory of all. Pkt., 25c; oz., $\$ 2.50 ; 1 / 4$ lb., $\$ 8.00$ : lb., $\$ 30.00$.

DRY WEATHER - This is a somewhat larger and later edition of Snowball.

Pkt., 25c; oz., $\$ 3.00 ; 1 / 4$ lb., $\$ 8.00 ; 1 b .$, $\$ 30.00$.

EXTRA EARLY DWARF ERFURT-One of the earliest varieties.

Pkt., 20c; oz., $\$ 3.00 ; 1 / 4$ lb., $\$ 8.00$; lb., $\$ 26.00$.

DANISH GIANT or DRY WEATHERRecommended for localities subject to long dry seasons as it will produce heads of fine quality where all else fails.

Pkt., 25c; oz., $\$ 2.50 ; 1 / 4$ lb., $\$ 8.00$; lb., $\$ 30.00$.

EARLY DWARF ERFURT-Produces goodsized, creamy white heads, one of the best for general cultivation. Similar to Snowball but later and of larger growth.

Pkt., 25c; oz., $\$ 2.00 ; 1 / 4$ lb., $\$ 5.00 ; 1 b$. $\$ 20.00$.

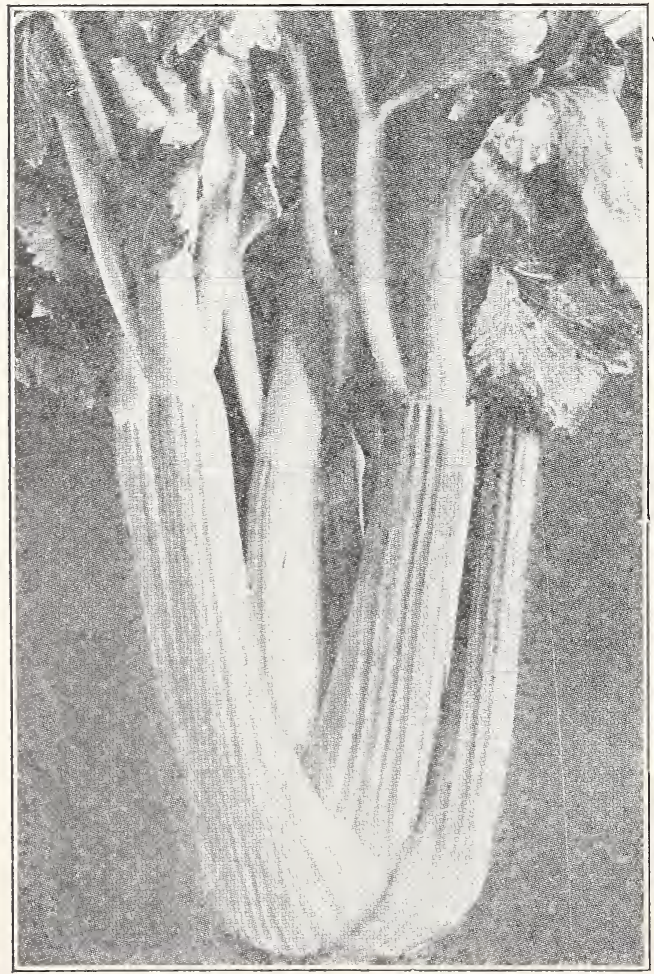

Easy Blanching Celery

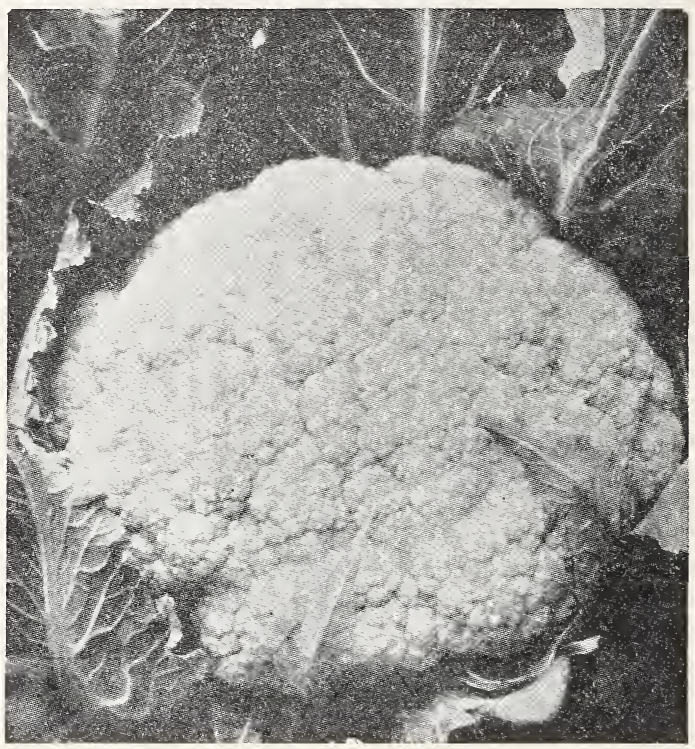

Snowball Cauliflower

\section{CELERY}

EASY BLEACHING - This is a valuable and comparatively new variety, which follows about two weeks later than Golden Self Blanching. It grows well on both muck and upland, has splendid leeping qualities, and is not as susceptible to blights as some other sorts. We have a very choice strain and recommend it highly.

Pkt., 10c; oz., 50c; 1/4 lb., \$1.25; lb., \$3.50.

WONDERFUL-This by far surpasses all others in size, hardiness and crispness. It is the last word in Celery. (See page 2.)

Pkt., 25c; oz., $\$ 2.00 ; 1 / 4$ lb., $\$ 5.00 ; 1 b .$, $\$ 12.00$.

GOLDEN SELF.BLANCHING or PARIS GOLDEN-The finest in quality. The stocky plants with broad thick stalks blanch easily to a clear waxen yellow.

FRENCH GROWN-Pkt., 25c; oz., $\$ 2.00$; 1/4 lb., $\$ 5.00 ;$ lb., $\$ 12.00$.

AMERICAN GROWN-Pkt., $10 \mathrm{c}$; oz., 75c: $1 / 4$ lb., $\$ 2.00$; lb., $\$ 7.00$.

GOLDEN PLUME-See Wonderful.

WHITE PLUME - The earliest Celery in cultivation. Pkt., 10c; oz., 35c; 1/4 lb., \$1.20; lb., $\$ 3.50$.

GIANT PASCAL-This one of the finest of the Green Winter Celeries. Of finest flavor. Pkt., 10c; oz., 35c; 1/4 lb., \$1.10; lb., \$3.50.

All following sorts: Pkt., 10c; oz., 30c; 1/4 lb., 75c; lb., $\$ 3.00$.

Woodruff's Beauty

Giant Golden Heart

Winter Queen

Boston Market

Celeriac, or Turnip Rooted Celery 


\section{CUCUMBER}

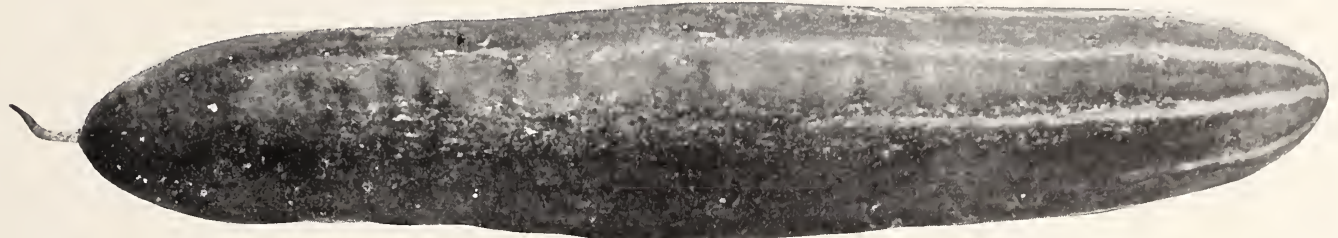

Woodruff's Hybrid Cucumber

Our principal reason for selecting this strain was its freeness from blight. It is more robust, hardier and a bigger cropper than any other. The seed has been selected from staked hills, not from selected fruits. This is the finest strain of market Cucumber in existence. It is early, dark green in color, a good shipper, and a tremendou; yielder, with fruit longer than the usual White Spine. Pkt., 10c; oz., 20c; $1 / 4$ lb., $75 \mathrm{c}$; lb., $\$ 2.00 ; 10$ lbs., $\$ 17.50$.

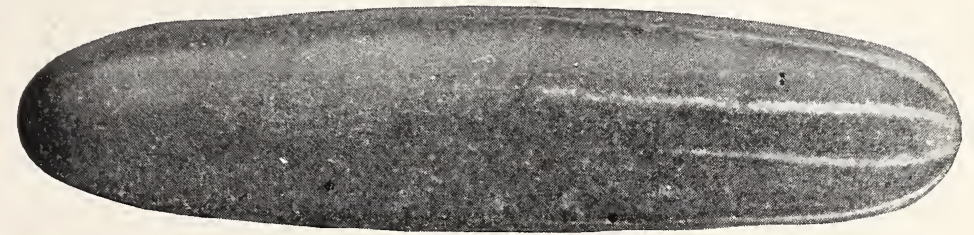

DAVIS PERFECT
D A V I S PERFECTAn extra long, dark green type of White Spine; retains its color and good qualities long after being picked; fruit is exceptionally long, smooth, a n d tapering at both ends; flesh crisp solid.

Pkt. Oz. 1/4 lb. $1 \mathrm{lb}$.

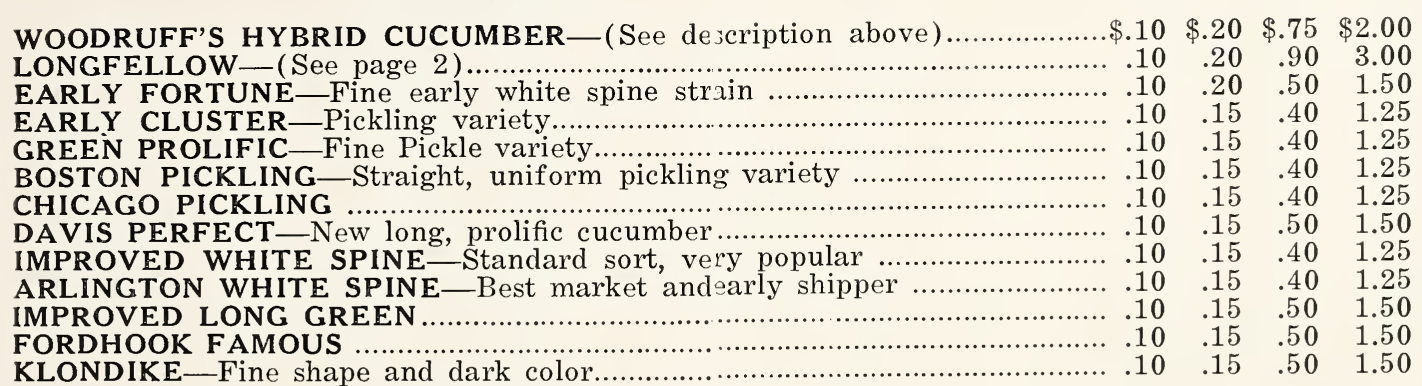

EARLY FORTUNE-The finest type of White Spine yet produced. Early, very productive and disease-resistant; fruits nine inches long, slightly tapering; flesh white, very firm and crisp, with very few seeds;

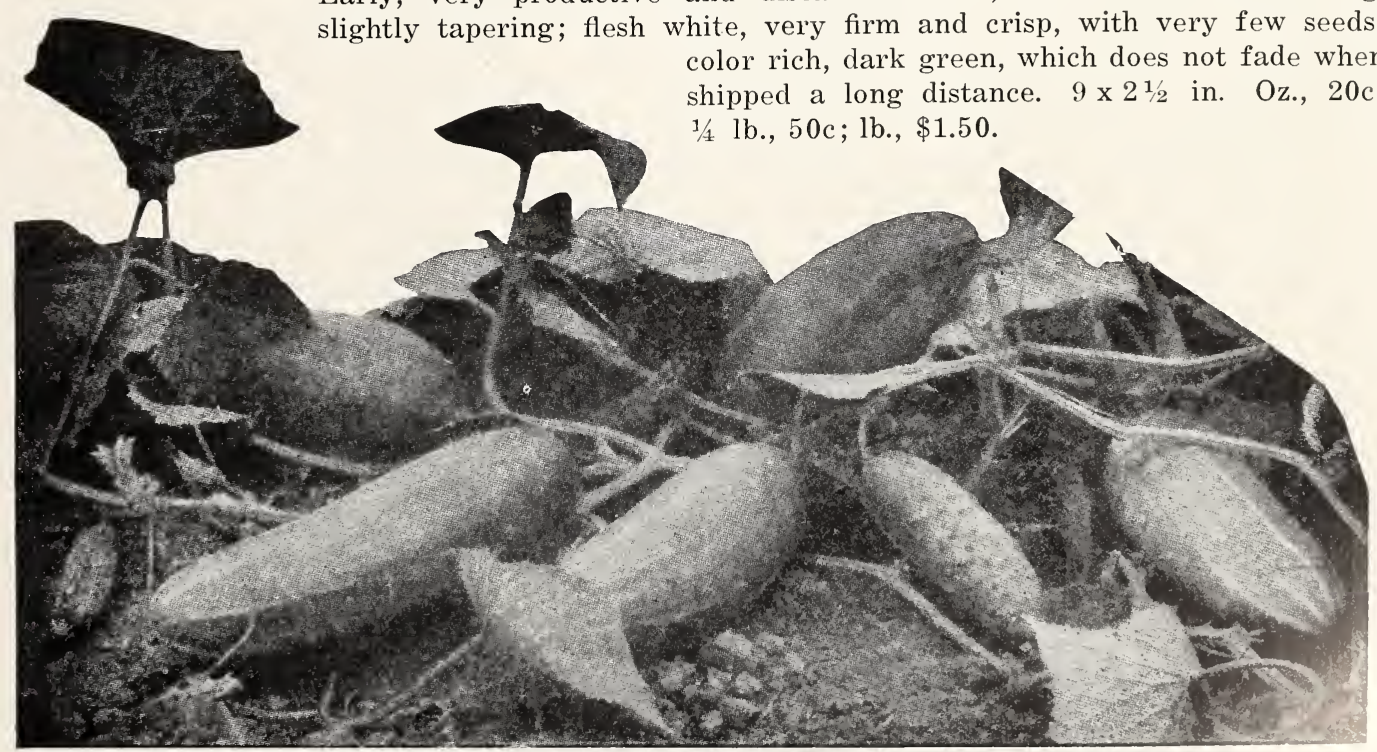

Early Fortune Cucumber 


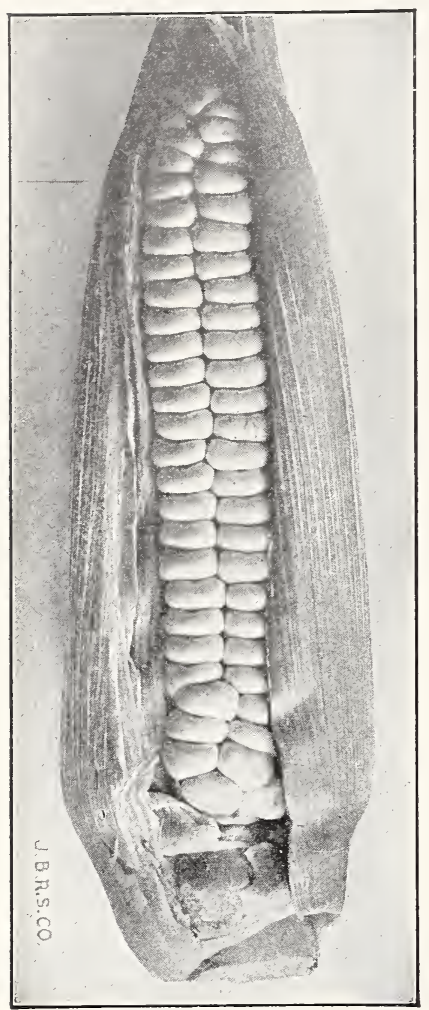

Golden Banıam

The Standard of them all We have a wonderful selected strain and there is no corn to compare with it in flavor.

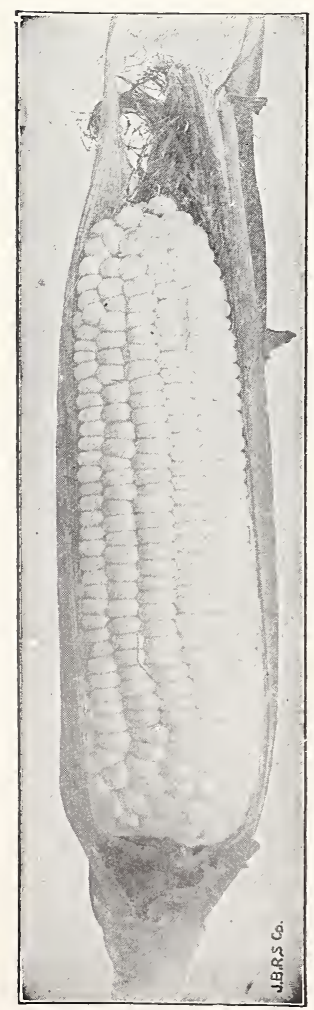

Whipple's Early Yellow

\section{CORN \\ YELLOW SEEDED VARIETIES}

Sweet Corn growers everywhere will find that the demand for these yellow seeded sorts of sweet corn is growing. In many markets they bring better prices and meet a greater demand than the older white varieties.

NEW GOLDEN SUNSHINE is the Best Early Improved Type of Golden Bantam yet introduced. Actually 13 days earlier.

Pkt., 25c; qt., 70c; pk., $\$ 4.00$; bu., $\$ 15.00$. See page 3 .

\section{GOLDEN BANTAM}

-Others are EarlierOthers are BiggerOthers are B etter Yielders-But none as yet have the Real Golden Rantam Quality.

Pkt., 20c; qt., 40c ; pk., $\$ 2.75$; bu., $\$ 8.00$.

\section{WHIPPLE'S EARLY} YELLOW-A remarkable new yellow sweet corn of much merit. While the stalks grow 6 feet or more in height and the 14-rowed ears are 7 to 8 inches in length, this variety matures three days earlier than Golden Bantam. The kernels are broad, deep and of excellent quality.

Pkt., 20c; qt., 40c pk., $\$ 2.75$; bu., $\$ 8.00$.

\section{EARLY ORANGE}

One of the best of the Improved $1 \mathrm{ar} g$ e type Golden Bantam. It is a few days later than Bantam but considerably earlier than Bantam Evergreen. It is the Best of the Big Type Golden Varieties. It has fine flavor and a big yielder.

Pkt., 20c; qt., $40 \mathrm{c}$ pk., $\$ 2.75$; bu., $\$ 8.00$.

\section{GOLDEN GIANT}

Matures about one week later than $t h \mathrm{e}$ Bantam. Immense ears a $\mathrm{n} d$ smaller kernels. Ears eight inches long with twelve to sixteen rows of kernels.

Pkt., 20c; qt., 40c; pk., $\$ 2.75$; bu., $\$ 8.00$.

\section{BANTAM EVER GREEN}

A c ross between Golden Bantam a n d S to w ell's Evergreen with all the good qualities of each. Ears eight inches long. Twelve to fourteen rows, and of a rich golden yellow. Sweetness a $n d$ flavor like Golden Bantam.

Pkt., 20c; qt., 40c; pk., $\$ 2.75$; bu., $\$ 8.00$.

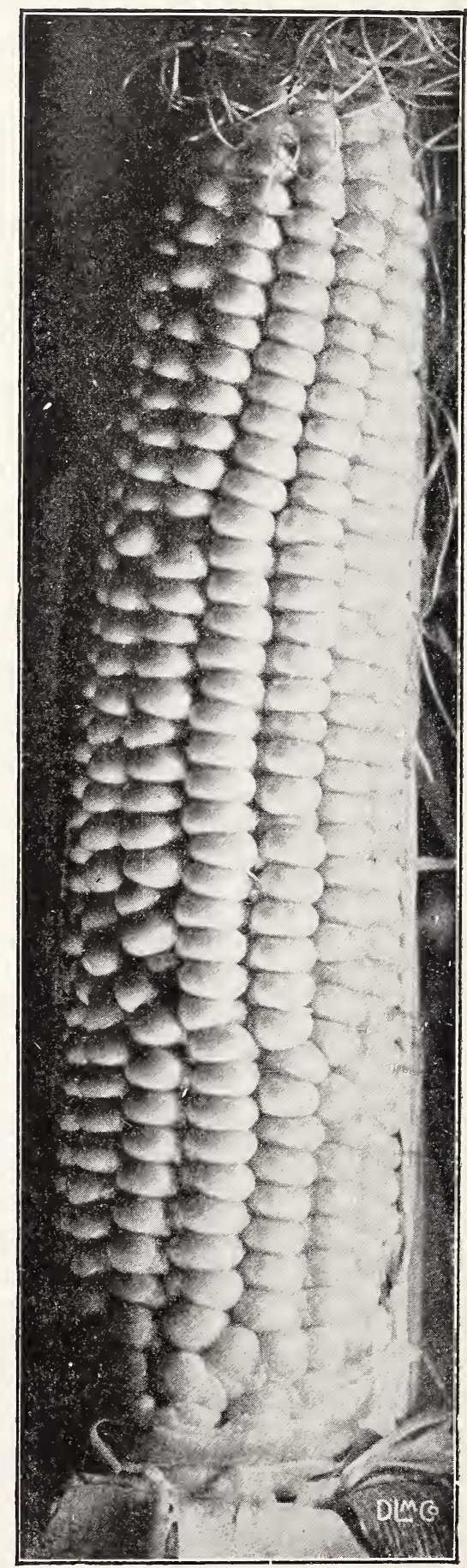

Golden Giant Sweet Corn 


\section{SWEET CORN \\ WHITE SEEDED VARIETIES \\ WOODRUFF'S EARLY MARKET}

A pure white sweet corn, having originated in the State of Oregon, beautifully tipped over and running 10 to 14 rows, and maturing exactly at the same date as Golden Sunshine Sweet Corn, which means it is thirteen days earlier in maturity than Golden Bantam, and a full seven days earlier than our Famous Early Dighton, and superior to Early Dighton in that it is a pure white corn and cob. We predict profitable crops of this really superb extra early white Sweet Corn.

Pkt., 25c; qt., 70c; pk., $\$ 4.00$; bu., $\$ 15.00$.

All sorts, pkt., 10c; pt., 25c; qt., 40c.

Per Per Per

Doz. Pk. Bu.

Ears

\begin{tabular}{|c|c|c|c|}
\hline Large Early Adams ............ & - & $\$ 2.50$ & $\$ 6.00$ \\
\hline Extra Early Adams ........... & . & 2.50 & 6.00 \\
\hline Early Champion ................ & $\$ 1.00$ & 2.50 & 8.00 \\
\hline Metropolitan & 1.00 & 2.50 & 8.00 \\
\hline Mammoth White Cory ......... & 1.00 & 2.50 & 8.00 \\
\hline 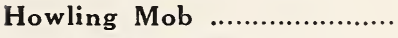 & 1.00 & 2.50 & 8.00 \\
\hline Early Mayflower ..................... & 1.00 & 2.50 & 8.00 \\
\hline Black Mexican ..................... & - & 2.50 & 8.00 \\
\hline Crosby's Early ..... & 1.00 & 2.50 & 8.00 \\
\hline Early Evergreen .................. & 1.00 & 2.50 & 8.00 \\
\hline Stowell's Evergreen .......... & 1.00 & 2.50 & 8.00 \\
\hline Long Island Beauty ............. & . 1.00 & 2.50 & 8.00 \\
\hline Country Gentleman ............. & 1.00 & 2.50 & 8.00 \\
\hline
\end{tabular}

SWEET FODDER CORN-Bu., $\$ 2.50 ; 10 \mathrm{bu}$. or over, $\$ 2.00$ per bu.

WHITE RICE POP CORN-The best corn for popping. Pt., 20c; qt., 35c; pk., $\$ 1.50$.

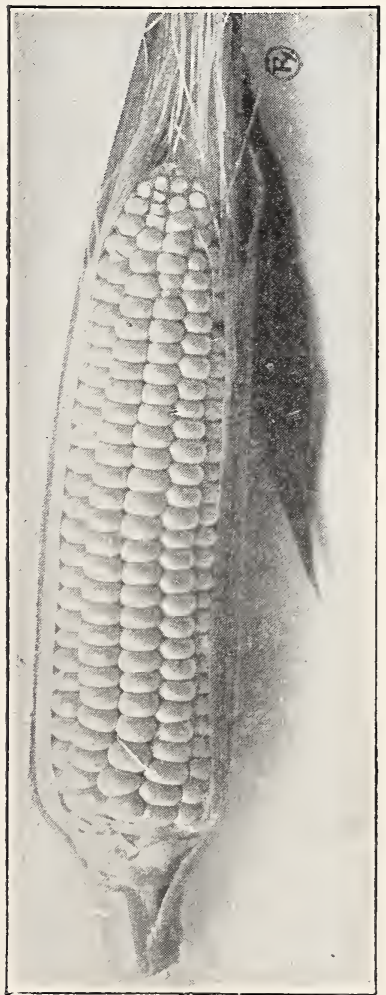

Woodruff's

Early

\section{EARLY MAYFLOWER}

-One of the whitest and sweetest of $\mathrm{the}$ early sorts. An exceptionally good yielder and one that deserves to be planted to come in ahead of Golden Bantam. Ears average 8 in. with deep kernel. Qt. $40 \mathrm{c}$; pk., $\$ 2.50$; bu., $\$ 8.00$.

LONG ISLAND BEAU. TY - The largest eared Sweet Corn grown. It is a late corn of wonderful quality and a tremendous yielder. The ears often measure 14 inches and the demand for it in the market is enormous. The real money made in sweet corn is to have it very early or very late. We made more money on our own Seed Farm at Orange, Conn., last summer on a c rop of Long Island Beauty Corn which we grew than on any other crop we grew-we could not anywheres near supply the demand-you can do the same in any town. Pk., $\$ 2.50$; bu., $\$ 8.00$; 100 selected ears, $\$ 10.00$.

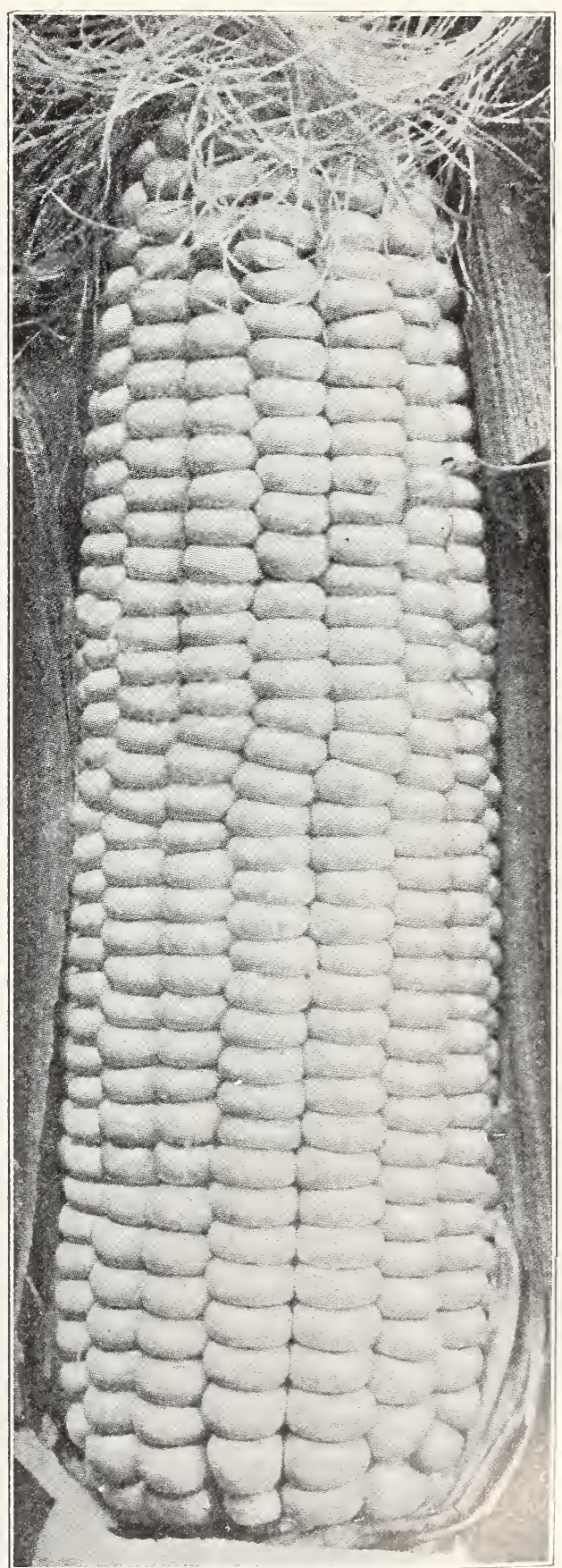

Bantam Evergreen Sweet Corn 
There is a real improvement in o $\mathrm{ur}$ P e d i g r e e d Stocks. It will pay you to try them.

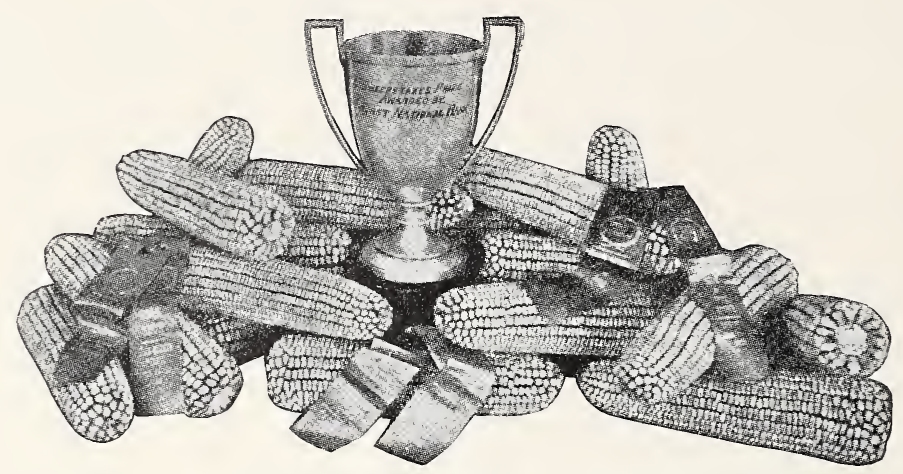

We can supply a $\mathrm{nd}$ ship promptly o n e b a g or 100 bushels of any s o r t of field corns.

\section{SWEEPSTAKES CORN}

Takes The Sweepstakes Cup

\section{FIELD CORN}

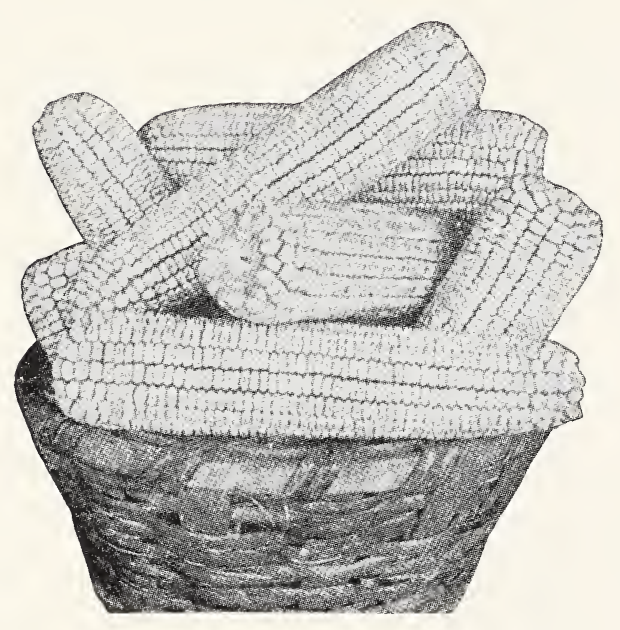

Genuine Eureka Ensilage

\section{SWEEPSTAKES SILO CORN}

Another popular yellow broad grain dent. Grows a very leafy stalk and matures its ears early. Pk., $\$ 1.25$; bu., $\$ 4.00$.

Early Flint varieties sure to mature in Northern New England. Sometimes called Yankee or Chicken Corn.

EARLY EIGHT-ROWED YELLOW CANADA -Very early Yellow Flint. Qt., 20c; pk., \$1.25; bu., $\$ 3.50$.

LONGFELLOW-Standard large yielding Yellow Flint. Qt., $20 \mathrm{c}$; pk., $\$ 1.25$; bu., $\$ 3.50$.

Above two varieties of Flints the best for Johnny Cake.

\section{WHITE VIRGINIA EUREKA}

Eureka grows as high as 16 feet when strongly fertilized, produces most tons of silage per acre. Its large white ears do not mature as early as the other varieties on this page. Our seed of this variety grows nearly perfect $98 \%$.

Pk., $\$ 1.00$; bu., $\$ 3.50$.

SANFORD - Standard large yielding White Flint. Qt., 20c; pk., $\$ 1.25$; bu., $\$ 3.50$.

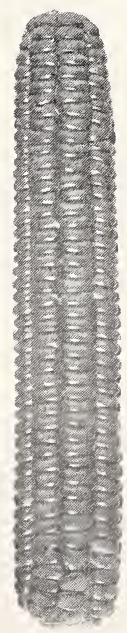

EARLY LEAMING-A brand new strain of Leaming, fully 10 days earlier than this popular sort, which gives it a very distinct advantage, especially in the most northern climates. Qt., 30c; pk., 90c; bu., $\$ 3.00$.

CUBAN GIANT ENSILAGE-A very large, leafy ensilage variety. A favorite in northern New England. Pk., 90c; bu., \$3.25.

PRIDE OF THE NORTH-Early, small cob Yellow Dent.

Qt., 20c; pk., 90c; bu., \$3.25.

EARLY MASTODON - Standard ensilage and main crop Yellow Dent.

Qt., 20c; pk., 90c; bu., $\$ 3.25$

RED COB ENSILAGE-The standard silo corn. Pk., 90c; bu., $\$ 3.25$.

REID'S YELLOW DENT - Pk., 90c; bu., $\$ 3.25$.

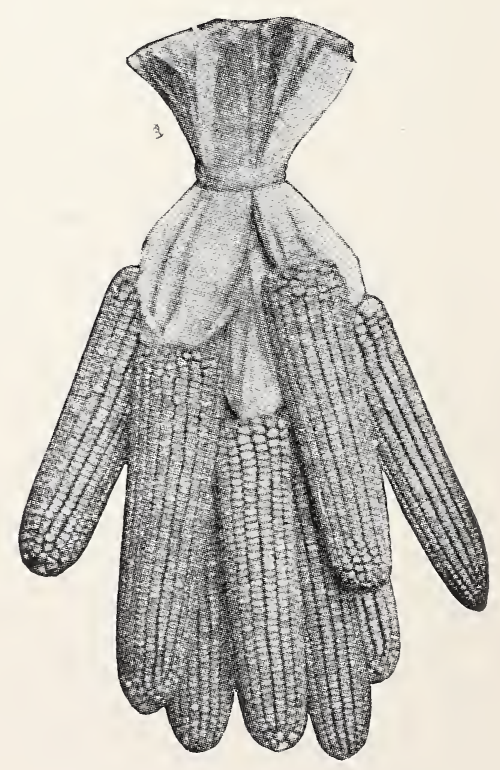

Early Improved Leaming 


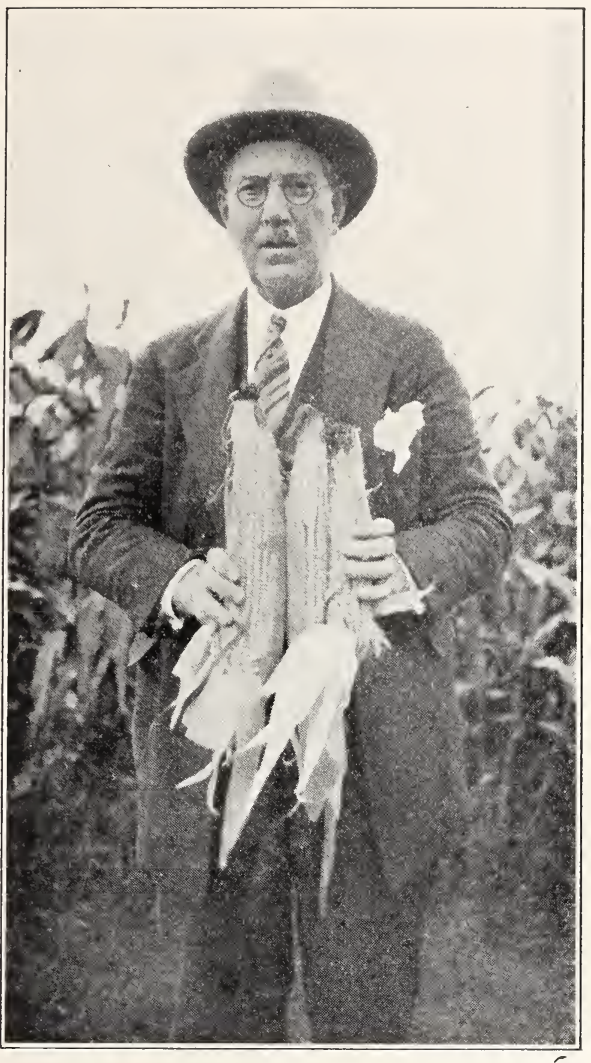

Mr. Little with three ears of Beauty Silo Corn from one stalk

\section{WOODRUFF'S BEAUTY SILO CORN}

\section{The Balanced Ration}

The most profitable corn that goes into the silo. Grows 10 to 14 feet. Early and matures its rich golden ears even in Northern New England. From a few bushels of seed first put out by us in 1923, our dairymen of the East now require from us many thousands of bushels annually. Peck $\$ 1.25$; bu., $\$ 4.00$.

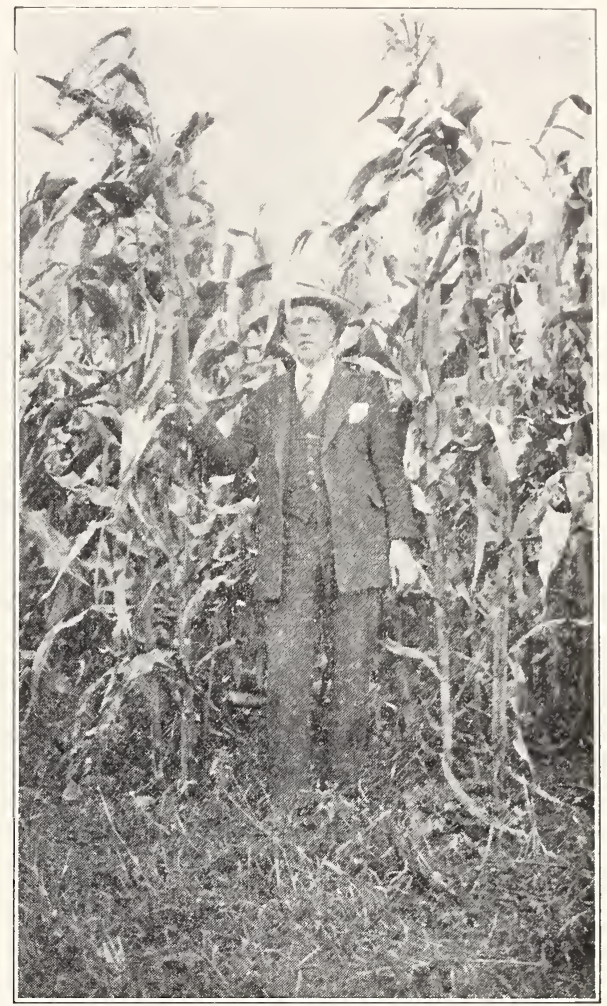

J. B. Garland \& Sons Crop of Woodruff's Beauty Silo Corn

S. D. Woodruff \& Son, Orange, Conn.,

Gentlemen:

The above is a photograph of Woodruff's Selected Beauty Ensilage Corn on the Holy Cross College Farm of Worcester, Mass. It was exactly 95 days from planting to cutting. The germination was practically $100 \%$, grew on an average of $12 \mathrm{ft}$. high and $75 \%$ of the stalks had two ears which measured on an average of 18 inches long. The ears were filled and fully matured for silo.

J. B. GARLAND \& SON, per William L. Little,

15 Grafton St., Worcester, Mass.

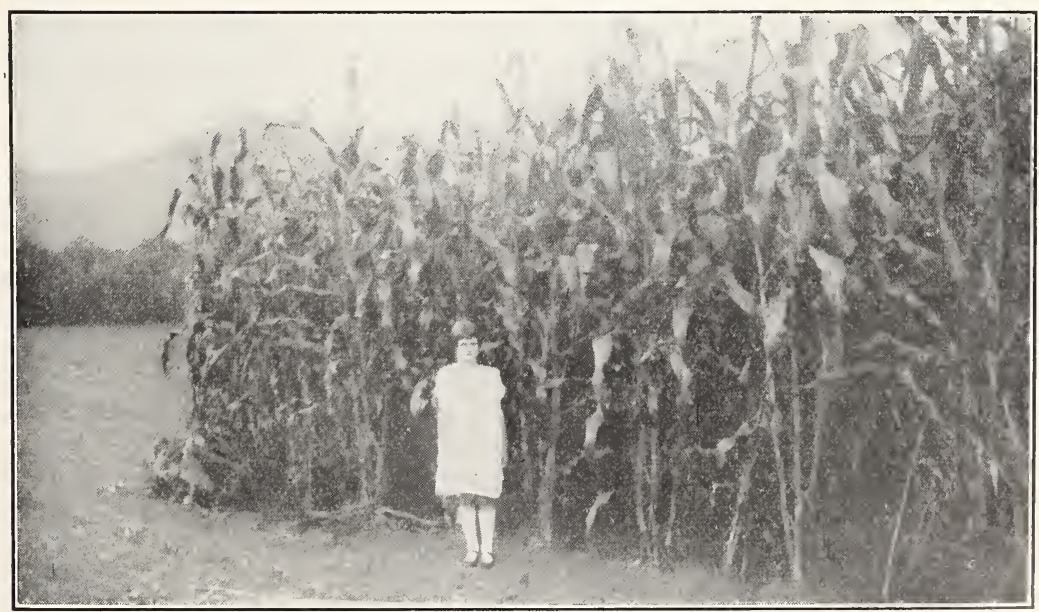

WOODRUFF'S SELECTED BEAUTY

"The Balanced Ration Ensilage Seed Corn" 


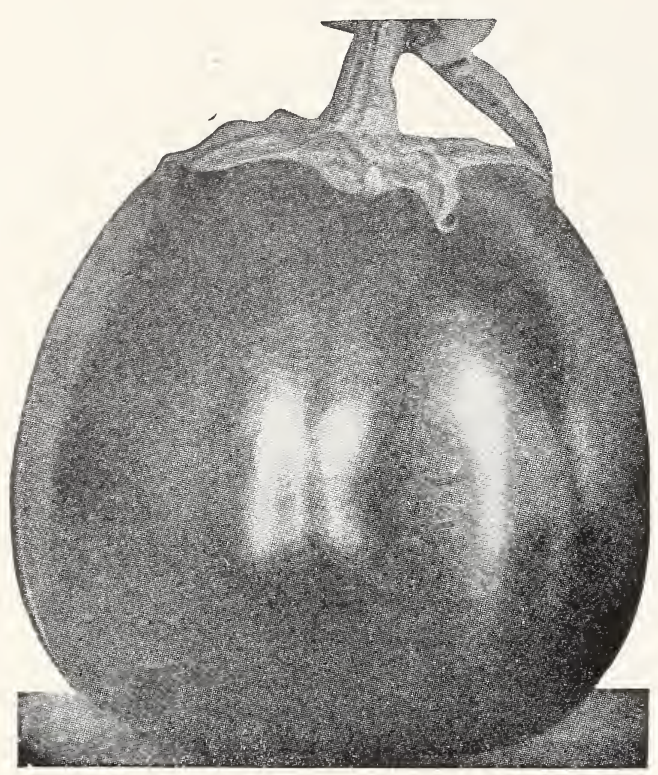

New York Improved Spineless

\section{EGG PLANT}

NEW YORK IMPROVED SPINELESS-The leading market variety, of large size, skin deep purple, smooth, free of thorns, flesh white, of excellent quality, very productive. Pkt., 10c; oz. $40 \mathrm{c} ; 1 / 4$ lb., $\$ 1.25 ; 1 \mathrm{~b} ., \$ 4.00$.

FLORIDA HIGH BUSH-Pkt., 10c; oz., 45c; $1 / 4$ lb., $\$ 1.25 ;$ lb., $\$ 4.00$.

BLACK BEAUTY - Earliest and best fruited sort. Pkt., 10c; oz., $45 \mathrm{c} ; 1 / 4$ lb., $\$ 1.25 ; 1 \mathrm{~b}$., $\$ 4.00$.

LONG PURPLE-Pkt., 10c; oz., 45c; 1/4 lb., $\$ 1.25 ; 1 b ., \$ 4.00$.

\section{DANDELION}

IMPROVED LARGE LEAF-Oz., 75c; 1/4 lb., $\$ 2.00 ; 1 b ., \$ 7.00$.

COMMON CULTIVATED-Pkt., 10c; oz., 40c; $1 / 4$ lb., $\$ 1.00 ; 1 b ., \$ 3.00$.

\section{ENDIVE (Escarolle)}

LARGE GREEN CURLED - A hardy variety, easily blanched. Pkt., 10c; oz., 20c; $1 / 4$ lb., 50c; lb., $\$ 1.50$.

BROAD LEAVED BATAVIAN - Large leaves, long and broad. Pkt., 10c; oz., 20c; 1/4 lb., 50c; lb., \$1.50.

\section{FENNEL}

FLORENCE or ITALIAN_Forms a bulb above ground at base of leaf stalk which is excellent when cooked. Pkt., 10c; oz., 20c; 1/4 lb., $40 \mathrm{c} ; 1 \mathrm{~b} ., \$ 1.50$.

\section{GOURDS}

NEST EGG, SUGAR TROUGH, DIPPER - Used principally for ornament. Each pkt., 10c; oz., $25 \mathrm{c}$.

\section{KALE}

DWARF GREEN CURLED SCOTCH-A very hixdy variety. Sow early in June and transplant like Cabbage in July. Pkt., 10c; oz., $25 \mathrm{c} ; 1 / 4$ lb., $60 \mathrm{c} ; 1 \mathrm{~b} ., \$ 1.50$.

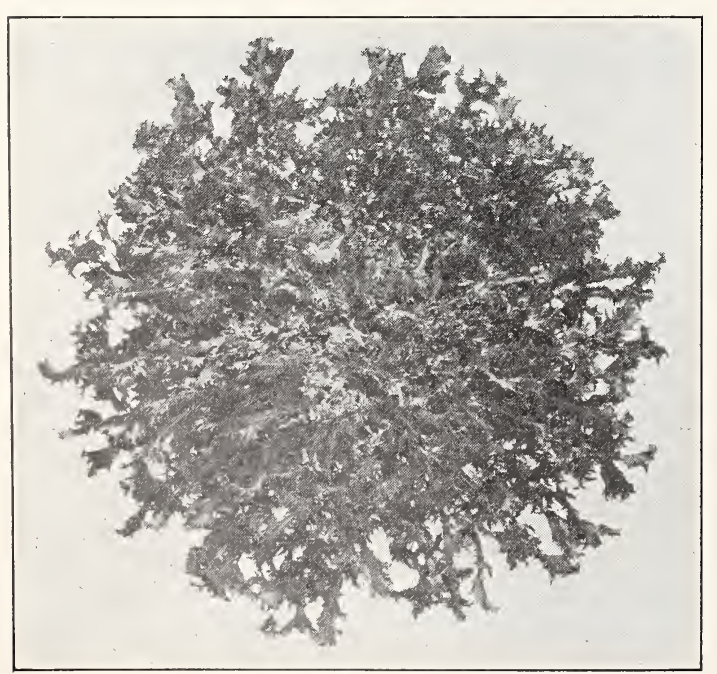

Green Curled Endive

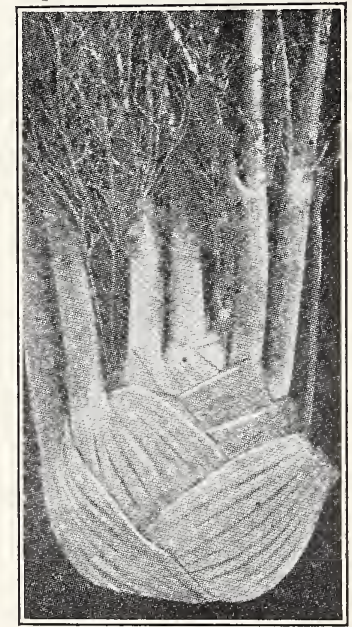

Italian Fennel

EARLY DWARF SIBERIAN or BLUE KALE - A very heavy cropper, and a great favorite in this locality. Sow in August in rows 15 inches apart and harvest next April or May. Pkt., $10 \mathrm{c}$; oz., $20 \mathrm{c} ; 1 / 4$ lb., $50 \mathrm{c}$; lb. $\$ 1.00$.

\section{KOHL RABI}

EARLY WHITE VIENNA-Pkt., 10c; oz., $25 \mathrm{c} ; 1 / 4$ lb., $75 \mathrm{c} ; 1 \mathrm{~b} ., \$ 2.50$

EARLY PURPLE'VIENN $/$ - - Pkt., $10 \mathrm{c} ;$ oz., $25 \mathrm{c} ; 1 / 4$ lb., $75 \mathrm{c} ; \mathrm{lb} ., \$ 2.50$.

\section{LEEK}

AMERICAN FLAG - A large standard variety. Pkt., 10c; oz., 25c; $1 / 4$ lb., 75c; lb., $\$ 2.50$.

LARGE MUSSELBURGH or CARENTAN -The largest in cultivation. Pkt., 10c; oz., $25 \mathrm{c} ; 1 / 4 \mathrm{lb}$., $75 \mathrm{c} ; 1 \mathrm{~b} ., \$ 2.50$. 


\section{LETTUCE}

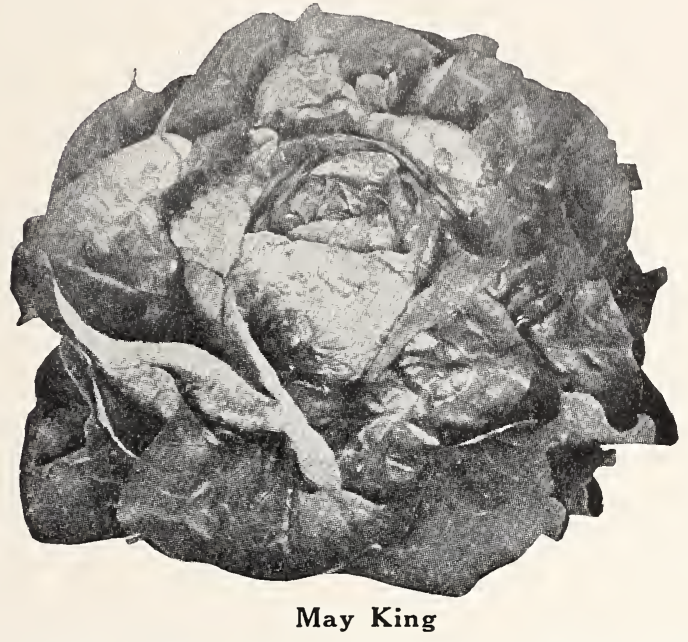

NEW EARLY MAY KING-An improved strain double the frame size of the original stocks. Heads very early and does equally well in open ground or under sash. Pkt., 10c; oz., 20c; 1/4 lb., 85c; lb., $\$ 3.00$.

BLACK SEED TENNIS BALL - Considered a standard for quality cabbage heading and slow to run to seed. Pkt., 10c; oz., 15c; $1 / 4$ lb., 50c; lb., $\$ 1.50$.

MARKET GARDENERS' PRIVATE STOCKMain crop sort which makes a large solid head and stands a long time before throwing a seed stalk. Pkt., 10c; oz., 15c; 1/4 lb., 50c; lb., $\$ 1.50$.

SALAMANDER-Probably the best compact lettuce for outdoor use. Will withstand summer heat without running to seed. Pkt., 10c;oz., 20c; 1/4 lb., $50 \mathrm{c} ; \mathrm{lb} ., \$ 1.50$.

HANSON - Heads large, green outside, white within. Our stock is very fine. Pkt., $10 \mathrm{c}$; oz., 20c; $1 / 4$ lb., 50c; lb., $\$ 1.50$.

PARIS WHITE COS ROMAINE-Large sort of Romaine. Excellent as a salad. Pkt., 10c; oz., 20c; $1 / 4$ lb., 60c; lb., $\$ 2.00$.

WHITE SEEDED SIMPSON-Loose curled head, similar to Black Seeded Simpson. Particularly suited for sowing thickly and cutting when plants are young. Pkt., 10c; oz., 15̄c; 1/4 lb., 40c; lb., $\$ 1.25$.

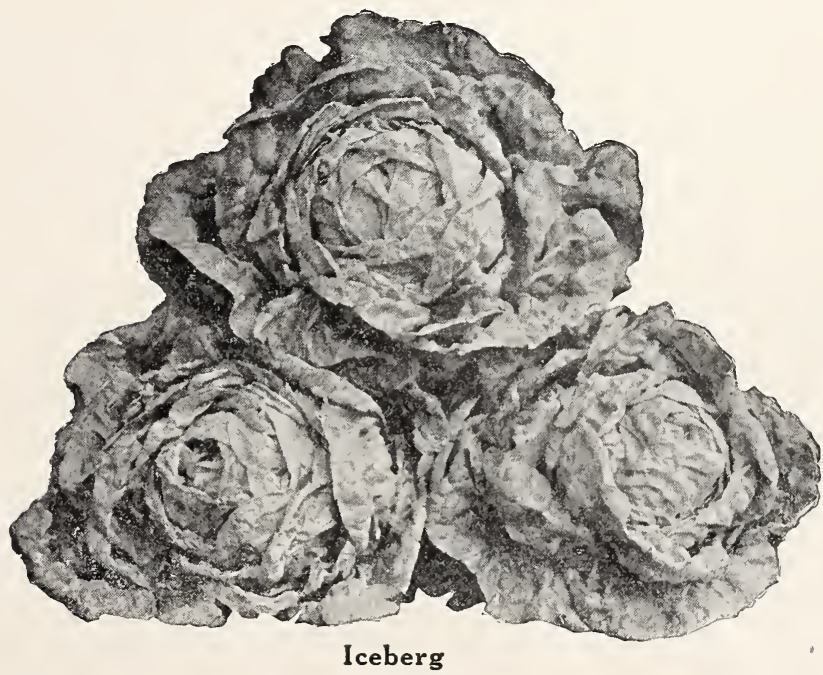

BIG BOSTON-The most popular of all Lettuces in the East. We offer a special selected stock. See page 3. Pkt., $10 \mathrm{c} ;$ oz., $20 \mathrm{c} ; 1 / 4$ lb., $75 \mathrm{c} ; 1 \mathrm{~b} ., \$ 1.50$.

NEW YORK or WONDERFUL-This variety produces heads of unusual size, frequently averaging $18 \mathrm{in.}$ in diameter and weighing from 3 to 4 pounds, and nearly as solid as cabbage. See page 3 . Pkt., 10c; oz., 25c; 1/4 lb., 85c; lb., $\$ 3.00$.

ICEBERG-One of the best varieties. Heads early and stands a long time before running to seed. Leaves finely cut and curled, very light green color, while the center of head is pure, crisp and of fine quality. Pkt., $10 \mathrm{c} ;$ oz., $25 \mathrm{c} ; 1 / 4 \mathrm{lb}$., $75 \mathrm{c} ; \mathrm{lb} ., \$ 2.50$.

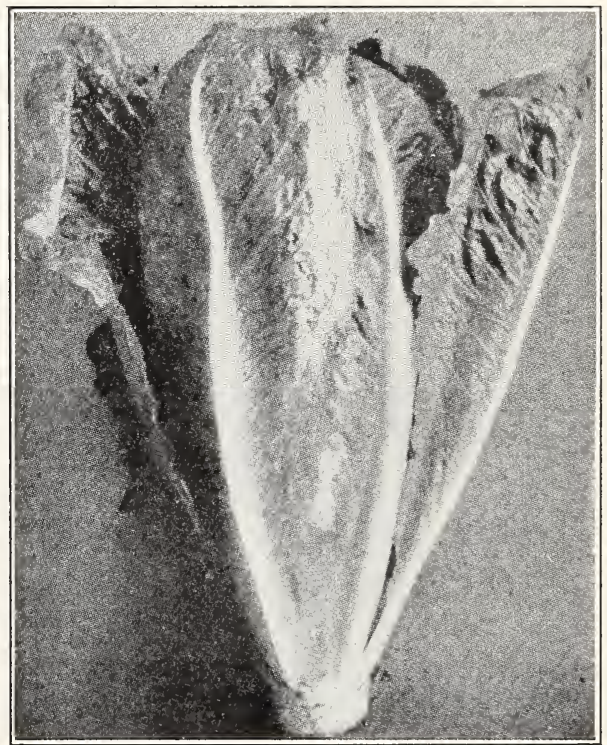

Romaine-Paris White Cos

PRIZEHEAD - Large clustering non-heading sort; most excellent for home garden as it is very early. Too tender for shipping. Leaves are fine, curled and crinkled, bright green tinged with brownish red. Pkt., $10 \mathrm{c}$; oz., 15c; 1/4 lb., 40c; lb., \$1.25.

BLACK SEEDED SIMPSONLarge loose head; nearly white and very tender. Pkt., $10 \mathrm{c}$; oz., $15 \mathrm{c} ; 1 / 4$ lb., 40c; lb., \$1.25.

GRAND RAPIDS-An old standard loose leaf curly variety for forcing or out door use. Will stand high temperature, does not wilt quickly after cutting, therefore a good shipper. Pkt., $10 \mathrm{c}$; oz., $15 \mathrm{c} ; 1 / 4 \mathrm{lb} ., 50 \mathrm{c}$; lb., $\$ 1.50$. 


\section{SALMON FLESHED CANTALOUPES}

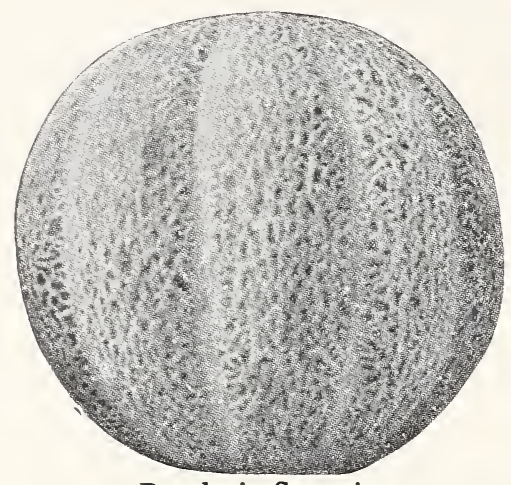

Bender's Surprise

BENDER'S SURPRISE - We consider the Bender melon the best flavor and finest eating melon we have ever tasted, and strongly recommend it over every other melon. The skin when ripe is light greenish yellow, the flesh a very deep salmon. It can be successfully grown as far north as Minneapolis. Pkt., 10c; oz., 25c; 1/4 lb., 85c; lb., $\$ 3.00$.

HEARTS OF GOLD-An excellent mid-season variety. Fruit round, distinctly ribbed and densely covered with fine grey netting. Flesh thick, fine quality and rich orange color. Pkt., 10c; oz., $15 \mathrm{c} ; 1 / 4 \mathrm{lb}$., 40c; lb., $\$ 1.25$.

HALE'S BEST or "H. B."-Decidedly the earliest of the yellow-fleshed Rocky Ford type. A remarkable early shipping melon from the Imperial Valley, Cal. Melons are oval in shape, with heavy netting. Flesh exceptionally thick and deep salmon in color. A most promising and profitable variety. Pkt., $10 c$; oz., 30c; 1/4 lb., 75c; lb., $\$ 2.00$.

OSAGE OR MILLER'S CREAM - A very high quality melon. Fruits are dark green, slightly ribbed and well netted. Rich orange salmon flesh and very sweet. Pkt., 10c; oz., $15 \mathrm{c} ; 1 / 4 \mathrm{lb} ., 35 \mathrm{c} ; \mathrm{lb} ., \$ 1.00$.

EMERALD GEM - One of the best early melons, and especially adapted for a home garden. Very sweet. Pkt., $10 \mathrm{c} ;$ oz., $15 \mathrm{c} ; 1 / 4$ lb., 35c; lb., $\$ 1.00$.

GRAND-10 to 14 days earlier than Osage. Pkt., 10c;oz., $20 \mathrm{c} ; 1 / 4$ lb., $40 \mathrm{c} ; 1 \mathrm{~b} ., \$ 1.25$.

TIP TOP - Shape round to slightly oblong, deep salmon color, sweet and spicy. Pkt., 10c; oz., 20c; 1/4 lb., 40c; lb., $\$ 1.25$,

\section{GREEN FLESH VARIETIES}

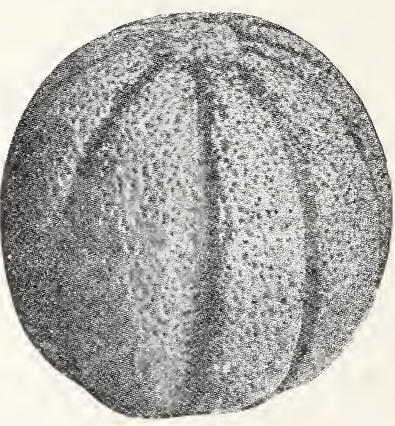

Hearts of Gold

JENNY LIND - Small fruit, with button on flower end. Pkt., $10 \mathrm{c}$; oz., $15 \mathrm{c} ; 1 / 4 \mathrm{lb}$., 35c; lb., $\$ 1.00$.

ROCKY FORD - Small round fruit, no ribs and heavily netted. Pkt., 10c; oz., 15c; 1/4 lb., 35c; lb., $\$ 1.00$.

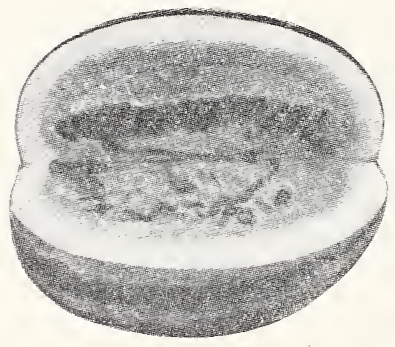

Cole's Early Watermelon

KLECKLEY'S SWEET - Fine for nearby markets; medium size, thin rind, flesh bright red and crisp.

IMPROVED LONG DIXIELarge, oblong, dark green a n d striped. Good eating and shipping qualities.

GEORGIA RATTLESNAKE-A Southern favorite. Very long, seeds white, light green.

HUNGARIAN HONEY-Early, for home gardens. Small size, seed small and brown.

TOM WATSON-A fine shipper, Rich red flesh. Price on all Watermelon: Pkt., 5c; oz., 10c; 1/4 lb., 25c; lb., 90c.
EARLY HACKENSACK - An old sort. Pkt., 10c; oz., $15 \mathrm{c} ; 1 / 4$ lb., 35c; lb., $\$ 1.00$.

LARGE HACKENSACK - Large round fruit. Heavily netted. Pkt., 10c; oz., 15c; 1/4 lb., 35c; lb., $\$ 1.00$.

HONEY DEW - Cassaba type, large oval fruit, smooth lemon tinted shell. Pkt., 10c; oz., 20c; 1/4 lb., 40c; lb., $\$ 1.25$.

\section{WATERMELON}

MOUNTAIN SWEET-Fairly early, medium to large size, very dark green and good quality.

ICE CREAM-One of the best for growing in the North; early; short and oblong; thin rind, flesh bright scarlet; seeds white, quality very good.

PHINNEY'S EARLY-Suitable for home gardens; size medium, oblong shape, quality very good; seeds light brown.

COLE'S EARLY - Very early. Fine for home gardens. Round and sweet.

SWEETHEART-Medium early, large size. Oblong, tough rind, and a good shipper. Light green, bright red flesh, very sweet, seeds black.

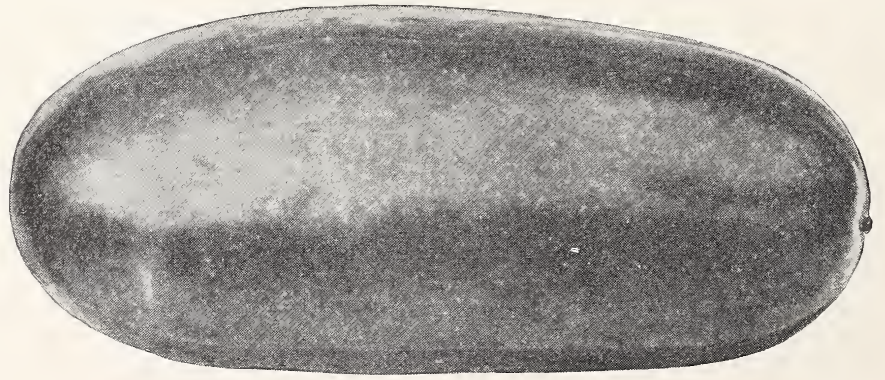

Tom Watson Watermelon 


\section{ONION SEED}

Really dependable stocks all carefully grown from hand selected bulbs-Pedigreed Stocks. Large packets all varieties, $10 \mathrm{c}$.

\section{EXTRA EARLY YELLOW-}

Half way between globe and flat. Ripens even. Three weeks earlier than Yellow Globe. Oz., 25c; $1 / 4$ lb., $75 \mathrm{c} ; \mathrm{lb} ., \$ 2.00$.

\section{YELLOW GLOBE DANVERS}

-Always a heavy yielder, has an excellent color, cures well, and makes splendid storage stock. Oz. $30 \mathrm{c} ; 1 / 4$ lb., $75 \mathrm{c} ; \mathrm{lb} ., \$ 1.75$.

\section{SOUTHPORT YELLOW GLOBE}

-The most largely grown yellow market onion and the most profitable. Bulbs are a true deep globe. Its heavy, thick skin makes it an excellent storage sort; color is deep yellow or golden-brown. Oz., $30 \mathrm{c} ; 1 / 4$ lb., $75 \mathrm{c} ; \mathrm{lb} ., \$ 1.75$.

OHIO YELLOW GLOBE-With the exception that it is distinctly flat bottomed, it resembles Southport Yellow Grobe in every respect; Michigan Yellow Globe is practically

SOUTHPORT RED GLOBE - The finest type and most popular red onion. Bulbs are distinctly globe-shaped, excellent keepers; color deep purplish red. We have an unlb., $75 \mathrm{c} ; \mathrm{lb}$., $\$ 1.75$.

SOUTHPORT WHITE GLOBE - Tru Southport Globe form with a thin, delicate skin of purest paper whiteness; flesh is snowywhite and exceedingly mild. 1/4 lb., $\$ 1.00 ; l b$. $\$ 2.75$.

WHITE PORTUGAL or SILVERSKIN-A large, flat, white onion of mild flavor. More extensively grown for sets than any other white variety. Also largely used as a pickler and for bunching. $1 / 4$ lb., $75 \mathrm{c}$; lb., $\$ 2.50$. the same. Oz., 30c; 1/4 lb., 75c; lb., $\$ 1.75$. equalled strain of this variety. Oz., 30c; 1/4

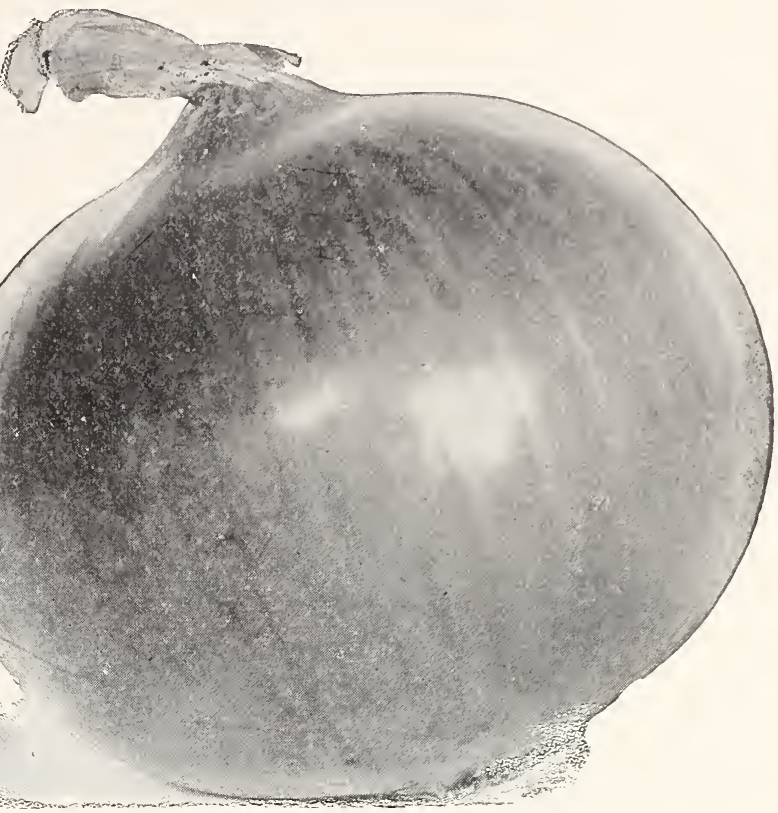

Yellow Globe Danvers

JAPANESE - The long keeping popular onion for growing Onion Sets. Fast becoming noted as a general market sort. Oz., 40c; 1/4 lb., $75 \mathrm{c} ; \mathrm{lb} ., \$ 2.00$.

PRIZETAKER - One of the largest onions grown and a sure cropper; bulbs globe-shaped of a light straw color. $1 / 4$ lb., $70 \mathrm{c} ; 1 \mathrm{~b} ., \$ 2.00$.

AILSA CRAIG-Oz., $40 \mathrm{c} ; 1 / 4$ lb., $\$ 1.00 ; 1 \mathrm{~b}$. $\$ 2.50$.

YELLOW DUTCH or STRASBURG-Used for sets. Oz., 30c; $1 / 4$ lb., 75c; lb., \$1.25.

AUSTRALIAN BROWN-Best keeping variety known. Oz., 30c; $1 / 4$ lb., 75c; lb., $\$ 2.00$.

MAMMOTH SILVER KING-Immense size. Oz., 40c; 1/4 lb., 90c; lb., \$2.50.

WHITE QUEEN or EXTRA EARLY BAR-

LETTA-Oz., 35c; 1/4 lb., 75c; lb., $\$ 2.00$.

EXTRA EARLY RED FLAT-Oz., 30c; $1 / 4$ lb., $75 \mathrm{c} ; \mathrm{lb} ., \$ 1.75$.

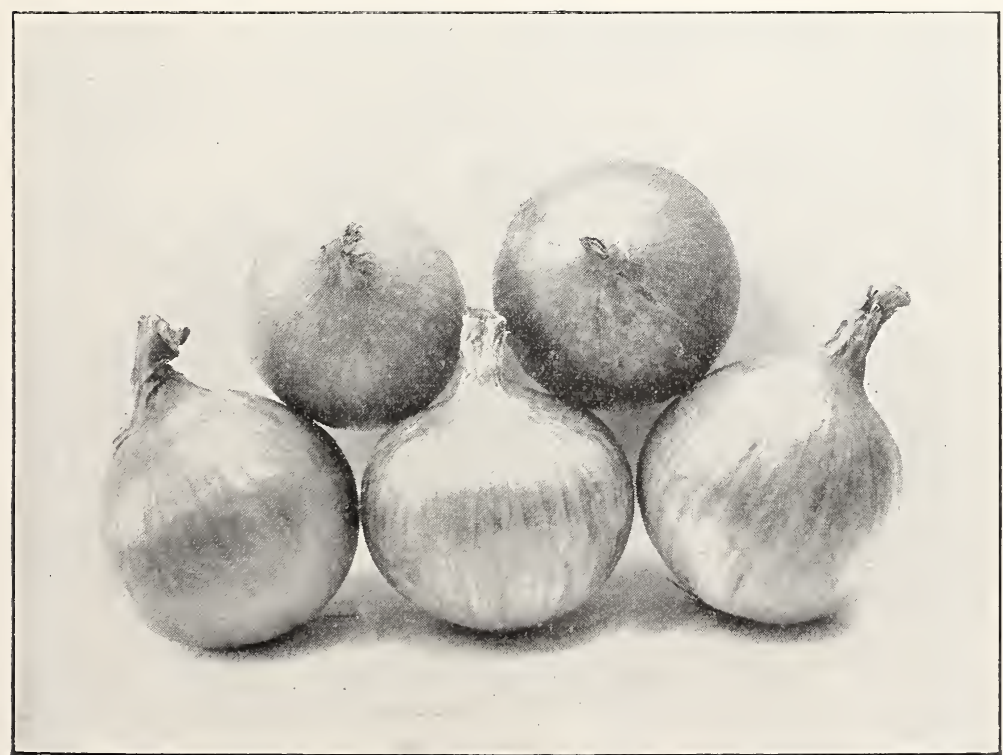

Southport Yellow Globe, Woodruff's Special XX Strain
LARGE RED WETHERSFIELD - Standard deep red. Oz., 30c; 1/4 lb., $75 \mathrm{c} ; \mathrm{lb.}, \$ 1.75 ; 5$ lbs., or over, $\$ 1.50 \mathrm{lb}$.

YELLOW BERMUDA -Teneriffe grown. New crop ready Sept. 1st, 1930. Oz., 40c; 1/4 lb., $\$ 1.00 ; 1 b ., \$ 2.50$.

CRYSTAL W H I T E WAX - Teneriffe grown. New crop ready Sept. 1st, 1930. Oz., 50c; 1/4 lb., $\$ 1.25$; lb., $\$ 3.50$.

OKRA or GUMBO

W H ITE VELVETPods round, smooth and free from seam. Pkt., 10c; $1 / 4$ lb., 35c; lb., 75c.

D W A R F GREENVery dwarf and prolific. Price same as above.

\section{MUSTARD}

G I A N T SOUTHERN CURLED - Oz., $10 \mathrm{c} ; 1 / 4$ lb., 25c; lb., 60c.

NEW CHINESE- $\mathrm{Oz}$

$10 \mathrm{c} ; 1 / 4$ lb., $30 \mathrm{c} ; 1 \mathrm{~b}, 60 \mathrm{c}$ 


\section{ONION SETS}

Qt. 8 lbs. 32 lbs.

Yellow Onion Sets........................\$. $.30 \quad \$ 1.00 \quad \$ 3.35$

Red Onion Sets........................... . .30 $1.00 \quad 3.25$

White Onion Sets......................... $40 \quad 1.50 \quad 4.50$

Japanese Onion Sets...................... .40 $1.25 \quad 3.50$

Potato or Multiplier Onion Sets........ $.40 \quad 1.25 \quad 4.00$

All prices quoted on Onion Sets are F. O. B. Orange, Conn., or New York City, 32 lbs., to the bushel. If by mail add 10c per quart to cover postage.

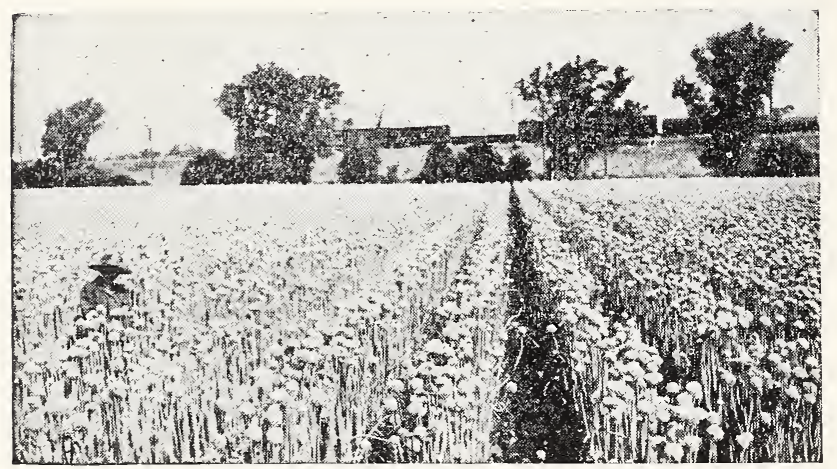

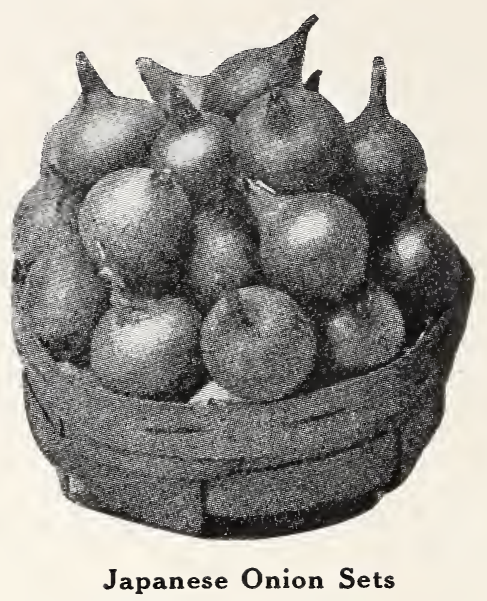

\section{JAPANESE ONION SETS}

Our large crop of several thousand bushels practically all sold before this catalogue was printed.

Price: Qt., 40c; 8 lbs., $\$ 1.25$; 32 lbs., \$3.50.

Field Yellow Globe Onion Seed

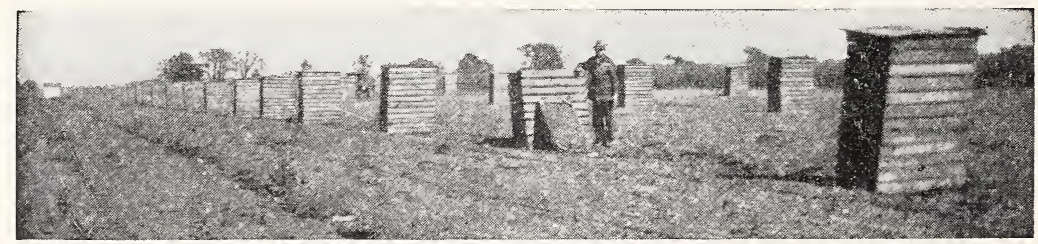

Harvesting Onion Sets

The Onion Sets are spread out thinly in crates, each pile of crates roofed over to prevent weather damage, after which they are taken into the permanent winter storage warehouses.

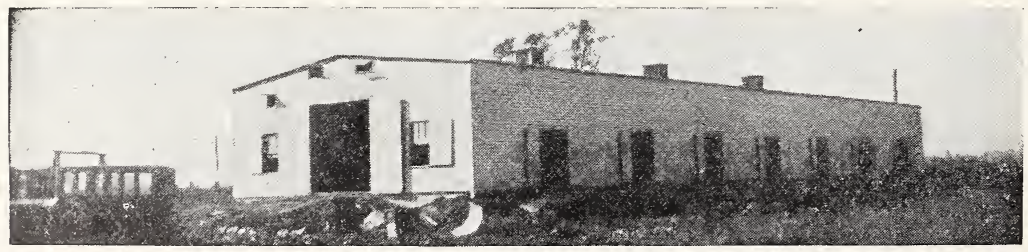

Onion Set Storage House

One of several of storage houses. This one is a 20,000 bushels capacity Onion Set storehouse in Cook County, Illinois. The Onion Sets are stored in frost-proof buildings, well ventilated, and spread out thin in crates. In the Spring the Sets are run through special machinery, consisting of fanning mill, belt conveyor and screens. This very careful handling of our Onion Sets account for the fine quality we are able to deliver to our customers each Spring.

Write for special prices if you plant large quantities of Sets 


\section{PEPPERS}

WOODRUFF'S COLLOSSAL - This is the finest stock of pepper that we have ever offered. Fruit very large, thick meated, beautiful red color, and absolutely sweet. The fruit is almost $100 \%$ four-pronged. Price: Pkt., 25c; oz., 75c; 1/4 lb., $\$ 2.50$; lb., $\$ 6.00$.

HARRIS' EARLY GIANT - The earliest and most prolific of all the large peppers. Two weeks earlier and yields three times as much as Ruby King, Chinese Giant and other large sorts. Pkt., 25c; oz., 75c; 1/4 lb., $\$ 2.50$; lb., $\$ 6.00$.

WORLDBEATER - Very large thick meated pepper, mild flavor, bright red, very productive. Pkt., 10c; oz., 40c; 1/4 lb., $\$ 1.40$; lb., $\$ 5.00$.

CRIMSON GIANT - Fully as large as Chinese Giant, earlier and more prolific; deep green when young, ripening to a bright scarlet; popular for stuffing. Pkt., $15 \mathrm{c}$; oz., 75c; $1 / 4$ lb., $\$ 2.50$; lb., $\$ 6.00$.

CHINESE GIANT - Enormous size. Big yielder. Pkt., $15 \mathrm{c}$; oz., $75 \mathrm{c}$; $1 / 4$ lb., $\$ 2.50$; lb., $\$ 6.00$.

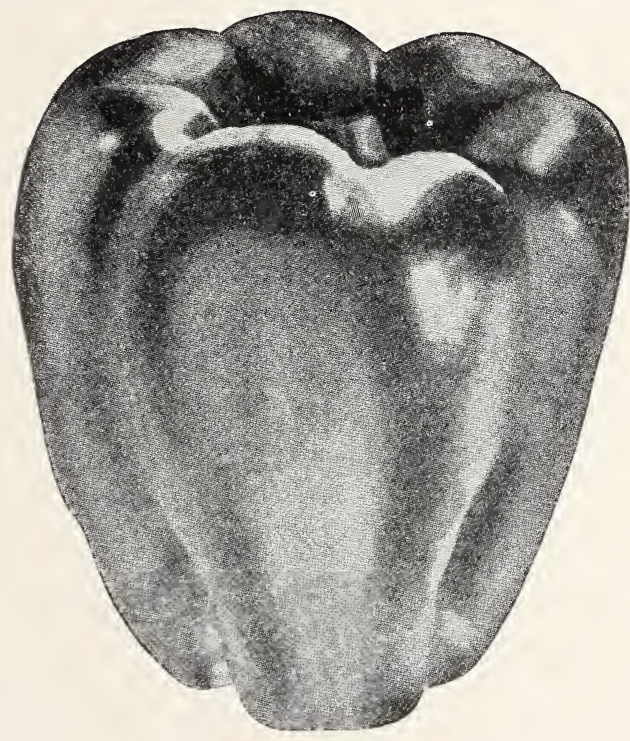

Worldbeater Pepper

\section{PARSNIP}

HOLLOW CROWN - The best, tender parsnip. Half long, wedge-shaped, hollow crowned. Pkt., 10c; oz., 20c; 1/4 lb., 40c; lb., $\$ 1.00$.

GUERNSEY - A greatly improved strain, hollow crown, very smooth. Pkt., $10 \mathrm{c}$; oz., $20 \mathrm{c} ; 1 / 4$ lb., 40c; lb., $\$ 1.00$.

\section{PARSLEY}

MOSS CURLED - The standard market sort. Our stock of this is extra double curled. Pkt., 10c; oz., 20c; 1/4 lb., 40c; lb., \$1.10.

PLAIN LEAF - A very hardy variety. Pkt., 10c; oz., 20c; 1/4 lb., 40c; lb., \$1.10.

HAMBURG ROOTED - This variety has edible roots, resembling parsnips, as shown in cut. Roots used for flavoring soups and stews. Top is Plain Leaf Parsley. Pkt., 10c; oz., $15 \mathrm{c} ; 1 / 1 / 4$ lb., $40 \mathrm{c} ; \mathrm{lb} ., \$ 1.25$.

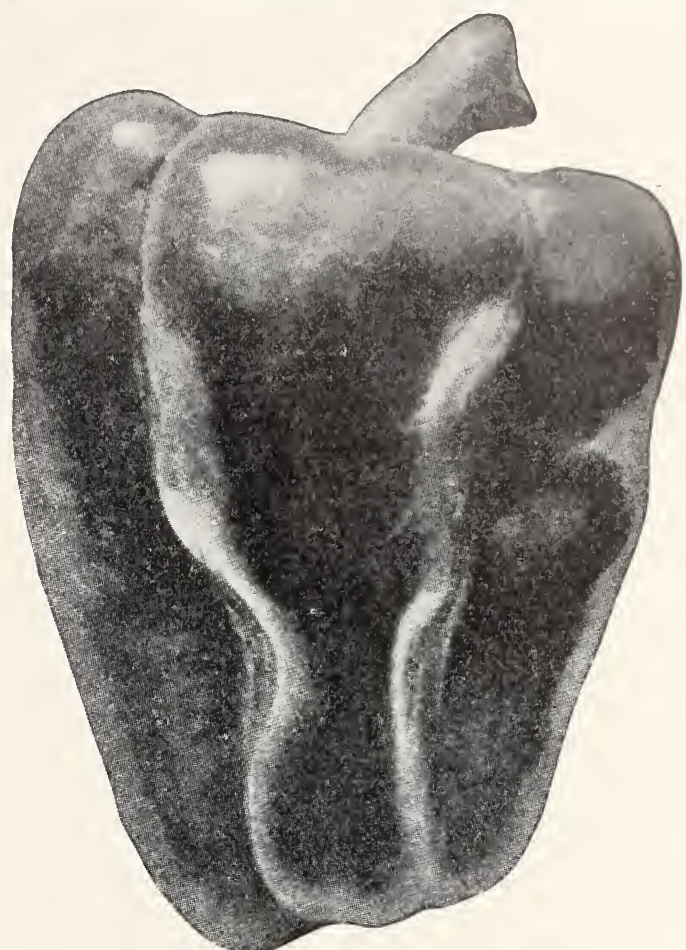

Harris' Early Giant Pepper

Peppers prices on following: Pkt., $10 \mathrm{c}$; oz., $50 \mathrm{c} ; 1 / 4$ lb., $\$ 1.25 ;$ lb., $\$ 4.00$.

NEW NEAPOLITAN-Mild flavor, large.

BULL NOSE_-Standard heavy yielding Hot Pepper.

SWEET MOUNTAIN-Mild, much longer than Bull Nose.

RUBY KING - Standard market variety.

SWEET SQUASH or CHEESE-Deep scarlet flat Pepper.

LARGE CHERRY RED-Hot.

SMALL CHILI-Best variety for pepper sauce.

LUNG RED CAYENNE_Fruit bright red. Hot.

PIMENTO.

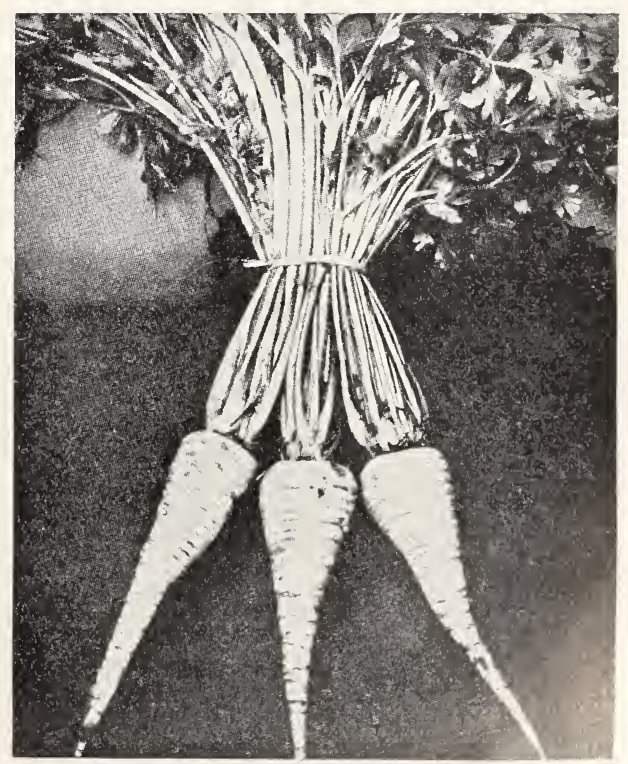

Hamburg or Hermisher Parsley 


\section{SQUASH}

Pkt., 10c; oz., 20c where not specified.

WOODRUFF'S NEW GIANT STRAIGHTNECK. See Novelties page 4. Pkt., 10c; oz., $35 \mathrm{c} ; 1 / 4$ lb., $\$ 1.00 ; 1 b ., \$ 3.00$.

SUMMER CROOKNECK-Standard Summer sort. $1 / 4$ lb., $40 \mathrm{c}$; lb., $\$ 1.25$.

GIANT SUMMER CROOKNECK-Larger than above. $1 / 4$ lb., 40c; lb., $\$ 1.50$.

WHITE BUSH SCALLOP_White and flat, with scalloped edges. 1/4 lb., 40c; lb., $\$ 1.00$.

MAMMOTH WHITE BUSH SCALLOPLarge fruited, 10 to 14 inches in diameter. $1 / 4$ lb., 40c; lb., $\$ 1.00$.

BOSTON MARROW-Bright orange color, standard sort. $1 / 4$ lb., 30c; lb., $\$ 1.00$.

HUBBARD-Hard, dark green, excellent quality. $1 / 4$ lb., $30 \mathrm{c} ; \mathrm{lb} ., \$ 1.00$.

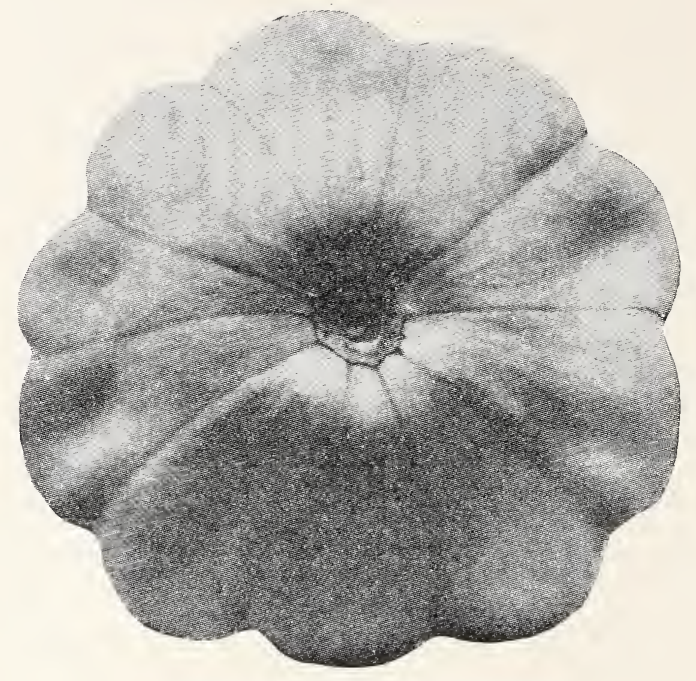

White Bush Scallop Squash

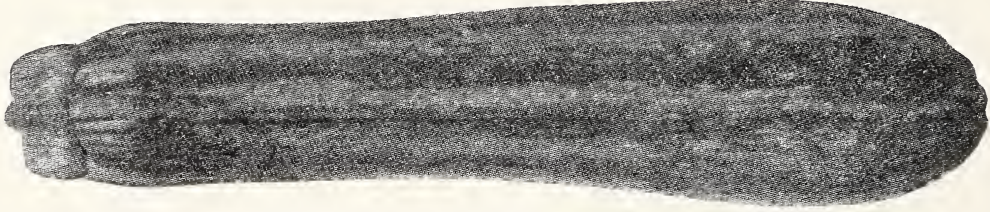

Italian Cocozelle Di Napoli

ITALIAN COCOZELLE (Cocozelle di Napoli)-A special selection grown for the most particular trade. A bush type with no runners. Produces yellow blossoms, the fruit is dark green with light colored stripes. The leaf is deeply cut, with light green veins. Pkt., $10 \mathrm{c}$; oz., $25 \mathrm{c} ; 1 / 4$ lb., $75 \mathrm{c}$; lb., $\$ 2.50$.

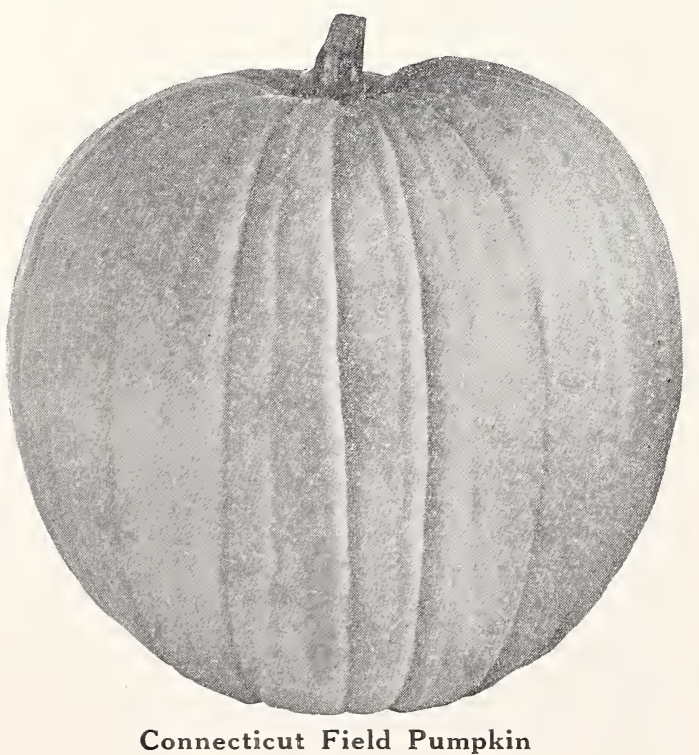

SYME'S BLUE HUBBARD-Has the same shape as Hubbard, has a very attractive bluish green color; meat is thick and golden orange. Very dry cooker and an excellent keeper. Pkt., 10c; oz., 20c; 1/4 lb., 60c; lb., \$2.00.

WARTED HUBBARD - Long keeper. 1/4 lb., 30c; lb., $\$ 1.00$.

GOLDEN HUBBARD - Orange - yellow. Fine keeper. 1/4 lb., 30c; lb., $\$ 1.25$.

ESSEX HYBRID or WARREN - $1 / 41 b$, $30 \mathrm{c} ; \mathrm{lb} ., \$ 1.25$.

DELICIOUS-A new golden skin and flesh, splendid quality. 1/4 lb., 40c; lb., $\$ 1.25$.

MAMMOTH CHILE - Grows to immense size. $1 / 4$ lb., 30c; lb., $\$ 1.00$.

\section{PUMPKIN}

Pkts. of each, $10 c$; ounce $15 c ; 1 / 41 b ., 30 c$; lb., 70c.

TENNESSEE SWEET POTATO.

KING OF THE MAMMOTH or GENUINE MAMMOTH.

SMALL SUGAR.

QUAKER PIE.

WHITE CUSHAW.

STRIPED CUSHAW.

JAPANESE PIE.

CONNECTICUT FIELD.

LARGE CHEESE or KENTUCKY FIELD. 


\section{PEAS}

\section{Early Laxtonian Types-Dwarf}

\section{LAXTON'S PROG-} GRESS - A dandy in our opinion. The pea grows on a dwarf vine; best type of second early pea yet introduced, pods very dark, exceptionally prolific, a very good shipper and owing to its color of pod and wonderful sh i p ping quality, is much sought after by those whose market requires a long railroad journey. Pkt., 20c; lb., $40 \mathrm{c} ; 100$ lbs., $\$ 20.00$.

PIONEER - This is a new variety of dwarf habit, vines 15 to 18 inches. The pods are $4 \frac{1}{2}$ inches long.

Pkt., $15 \mathrm{c} ; \mathrm{lb} ., 40 \mathrm{c}$; 100 lbs., $\$ 20.00$.

\section{BLUE BANTAM-A} new dwarf, early variety; very productive, bearing on 15 inch vines many large, wellfilled pods of luscious deep green peas, fully as large as Gradus.

Pkt., $15 \mathrm{c} ; \mathrm{lb} ., 40 \mathrm{c}$; 100 lbs., $\$ 20.00$.

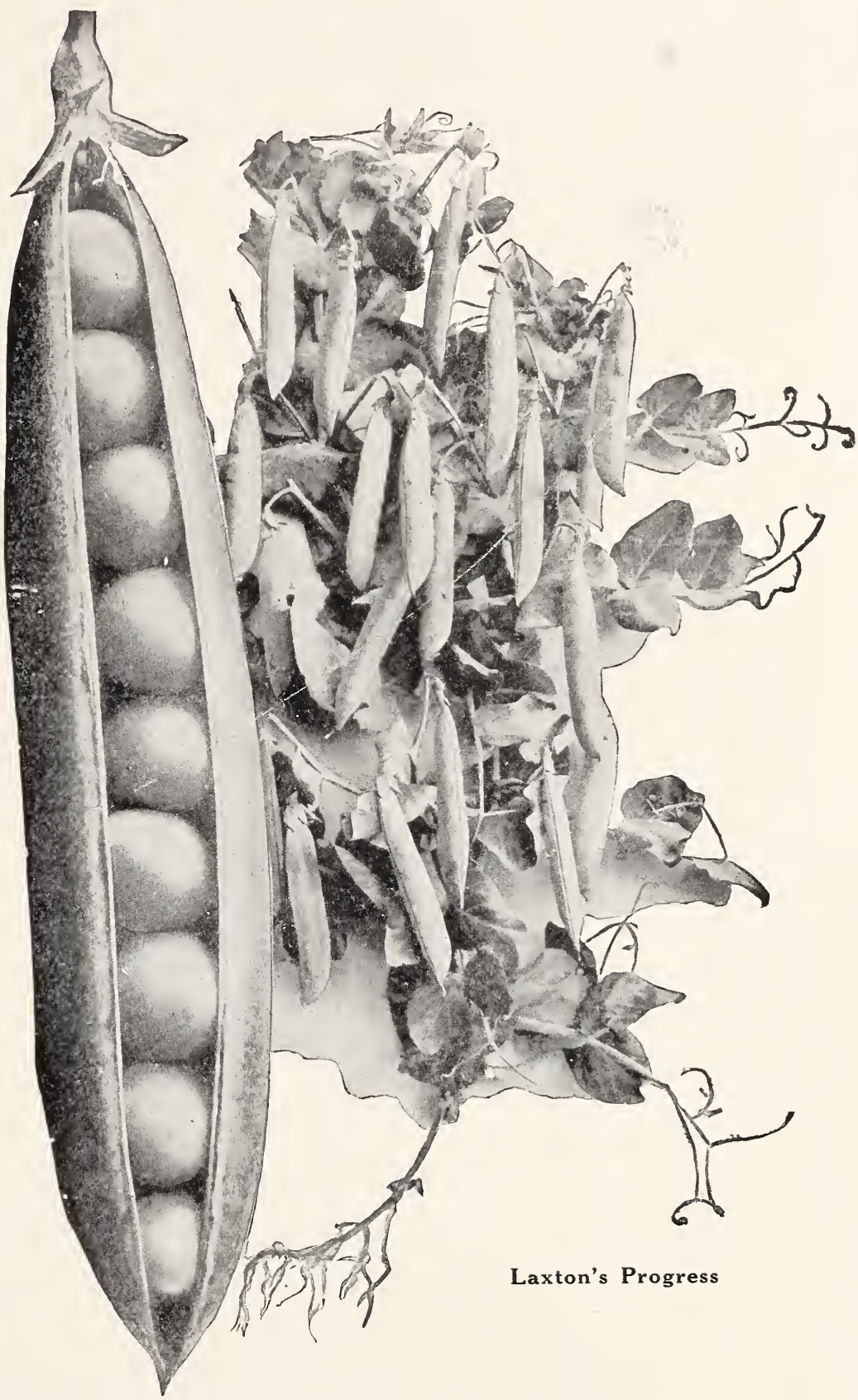

HUNDREDFOLD-One of the very finest of the large podded, dwarf peas, on the order of the Laxtonian, though somewhat earlier. Height, 15 inches. Vine and foliage stout, heavy and dark green, pods $3 \frac{3 / 4}{4}$ inches long, very broad, straight and pointed, containing 6 to 8 large, dark green peas of superb quality. Pkt., $15 \mathrm{c} ; 1 \mathrm{lb} ., 40 \mathrm{c} ; 100 \mathrm{lbs} ., \$ 20.00$.

LAXTON'S SUPERB - Biggest yielder of Laxtonian Type. An exceptionally early, hardy, productive, handsome pea. Height 16 inches. Vine and foliage moderately heavy, medium green, pods deep green, 4 inches long, semi-broad, pointed and well filled with 8 to 9 very large, dark green peas. As early as Laxtonian and more productive; seed blue, semi-wrinkled. Pkt., 15c; lb., 40c; 100 lbs.. $\$ 20.00$.

LAXTONIAN_Pods $3 \frac{112}{2}$ to 4 inches long, slightly curved. An easy pea to pick and a very heavy yielder. One of the best for home and market gardens. Pods and vines darks green. Height $1 \frac{1 / 2}{2}$ feet. Pkt., $15 c ; 1 b ., 40 c$; 100 lbs., $\$ 20.00$. 


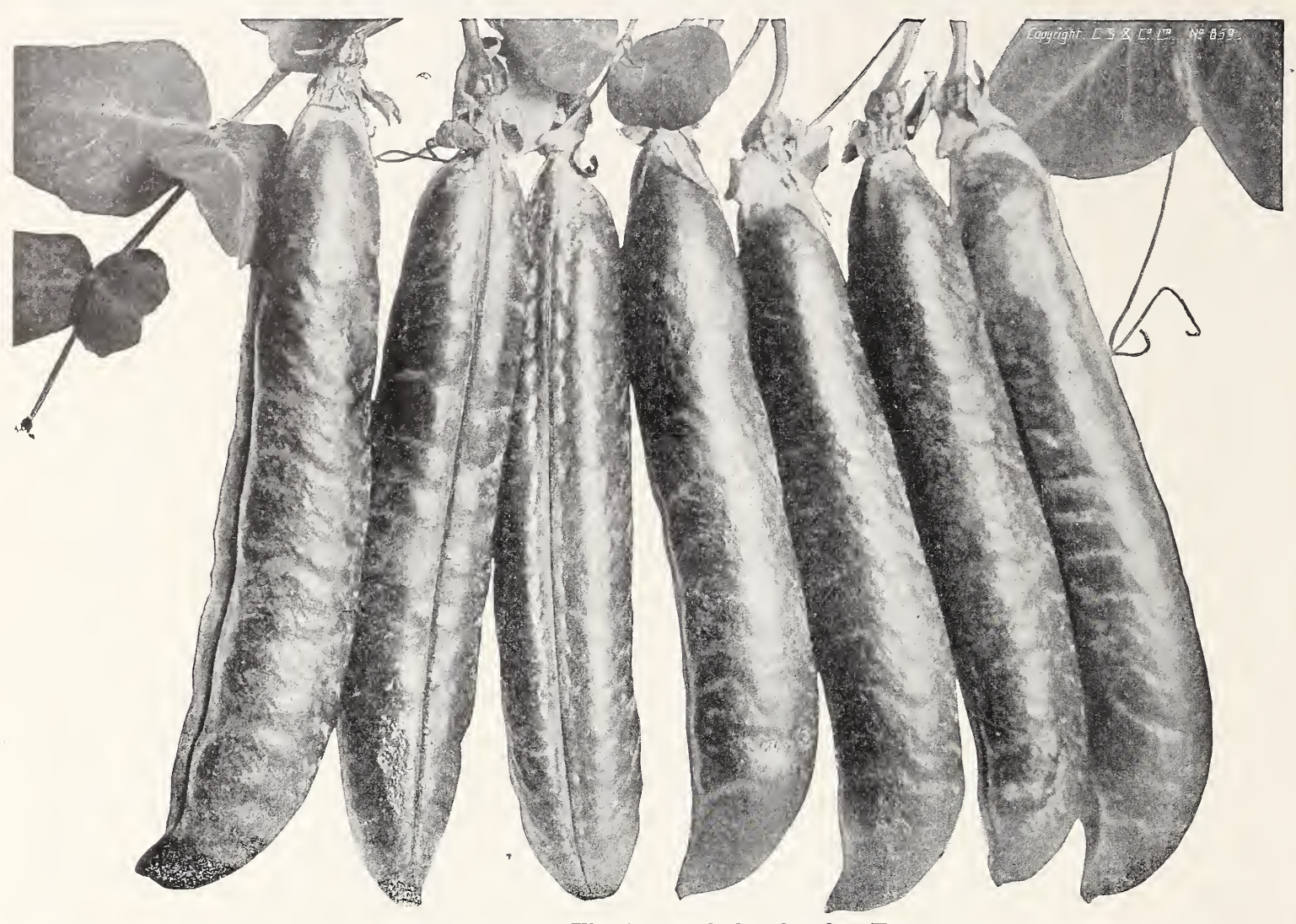

Marchioness-The Best of the Gradus Type

\section{PEAS}

\section{GRADUS AND THOMAS LAXTON TYPES}

MARCHIONESS-On order of Gradus, but earlier. Might well be termed an improved early Gradus. Vine and foliage moderately heavy and medium green in color; pods a shade darker, $3 \frac{1}{2}$ in. long, semi-round straight and pointed containing seven medium dark green peas. Pkt., 15c; lb., $40 \mathrm{c} ; 100$ lbs., $\$ 20.00$.

WORLD'S RECORD-An improved type of Gradus, being slightly earlier, more dwarf, true to type and productive. Height 2 feet. Vines moderately stout, medium green; pods medium green, 4 in. long, very broad, pointed and well filled with 7 to 9 very large, dark green peas of exceptional quality. Pkt., $15 \mathrm{c}$; lb., 40c; 100 lbs., $\$ 20.00$.

THOMAS LAXTON-A very popular gard-

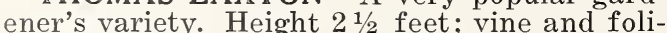
age moderately stout, medium green; pods medium green $3 \frac{1}{2}$ in. long, straight, nearly round and square ended, containing 7 medium dark green peas of superior quality. Compared with Gradus, is a little earlier, more productive, but with a smaller, less broad pod. Pkt., 15c; lb., 40c; 100 lbs., \$20.00.

GRADUS-Wrinkled variety, large pod and pea, tender and of good quality; pod 4 inches long, straight; height of vine, 36 inches. Pkt., $15 \mathrm{c} ;$ lb., 40c; 100 lbs., $\$ 20.00$.
BEST OF THE OLD STANDARD SORTS

The following varieties are all at standard prices. Pkt., 15c; lb., 25c; 100 lbs., $\$ 18.00$.

ALASKA, or EARLIEST OF ALL.

FIRST OF ALL-Selected strain of extra earlies.

NOTT'S EXCELSIOR. Heavy yielder; wrinkled variety; height of vine 15 inches.

AMERICAN WONDER-Height of vine 12 inches.

LITTLE MARVEL-Resembles Nott's Excelsior in vine and habits; height of vine 15 inches; wrinkled variety.

SUTTON'S EXCELSIOR-One of the finest dwarf peas in cultivation, especially for private and market gardeners.

PREMIUM GEM-A pea of fine flavor about two weeks later than American Wonder; is a good yielder; pods $2 \frac{1}{2} 2$ inches long.

ADVANCER-A dwarf green marrow, productive, fine flavor.

HORSFORD'S MARKET GARDEN-Similar to Advancer; prolific. 


\title{
MAIN CROP AND LATE
}

\section{PEAS}

\author{
All following - Pkt., 15c; \\ lb., 30c; 100 lbs., \$19.00.
}

DWARF TELEPHONE - Fine for home or market gardens. General habits of the Telephone, but a dwarf vine. Pods $4 \frac{1}{2}$ inches, pointed, and slightly curved. Light green color and set single and double. Vines 20 inches, 72 days to the table.

CHAMPION OF ENGLAND-A well known standard sort; one of the best.

DUKE OF ALBANY-Immense pods, a type of Telephone.

WOODRUFF'S D A R K PODDED TELEPHONE_Pods very large, filled with immense Peas. One of the best.

ADMIRAL DEWEY-Enormous pods, large wrinkled Peas of fine flavor.

PRINCE EDWARD-One of the largest podded Peas grown; pods 6 to 8 inches long; immense yielder.

ALDERMAN-An improvement over the old Telephone. Resists blight and drought; better than any other late Pea.

WHITE MARROWFAT - Price 100 lbs., $\$ 12.00$.

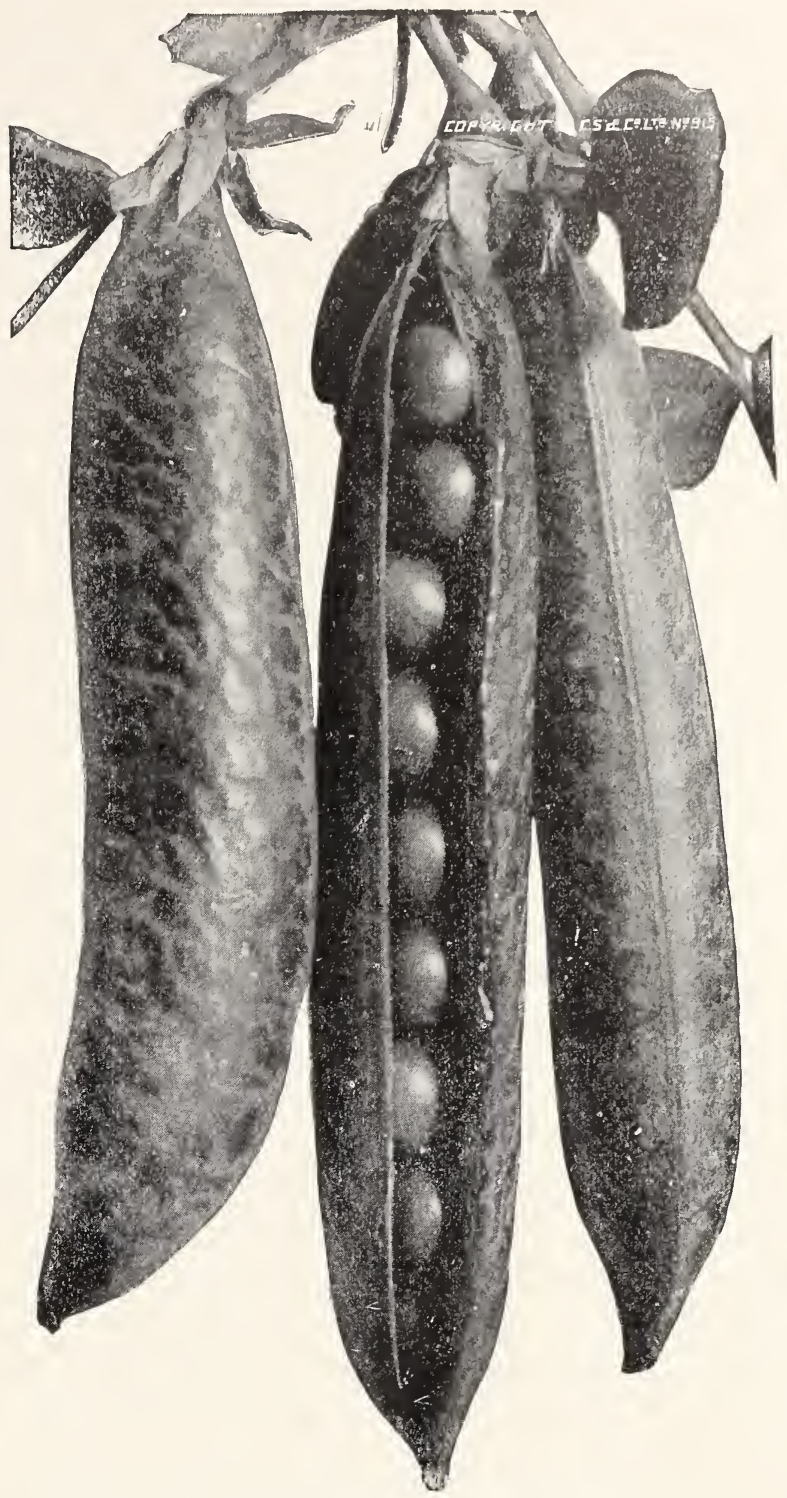

Woodruff's Dark Podded Telephone

\section{EDIBLE PODDED PEAS}

Pods Cooked Like Snap Beans

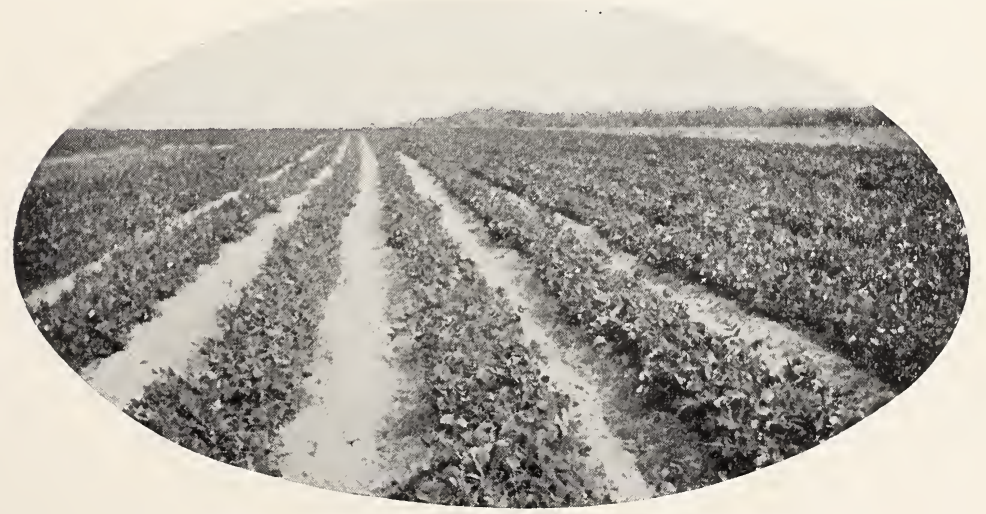

SUGAR, MAMMOTH MELTING - Tall White, Edible Pods, large broad pods, very brittle and entirely stringless. S e e d smooth and white. Season of Telephone. Pkt., $15 \mathrm{c} ;$ lb., $40 \mathrm{c} ; 100$ lbs., $\$ 25.00$.

S U G A R, D W A R F WHITE-Edible Pods, 6 light green peas to pod, quite early. Pkt., 15c; lb., $40 \mathrm{c} ; 100$ lbs., $\$ 25.00$.

SUGAR, GIANT LUS. CIOUS - Edible Pods.

Pkt., $15 \mathrm{c} ; 1 \mathrm{~b} ., 40 \mathrm{c} ; 100$

Field of Laxton's Superb Peas for Seed lbs., $\$ 25.00$. 


\section{SEED POTATOES}

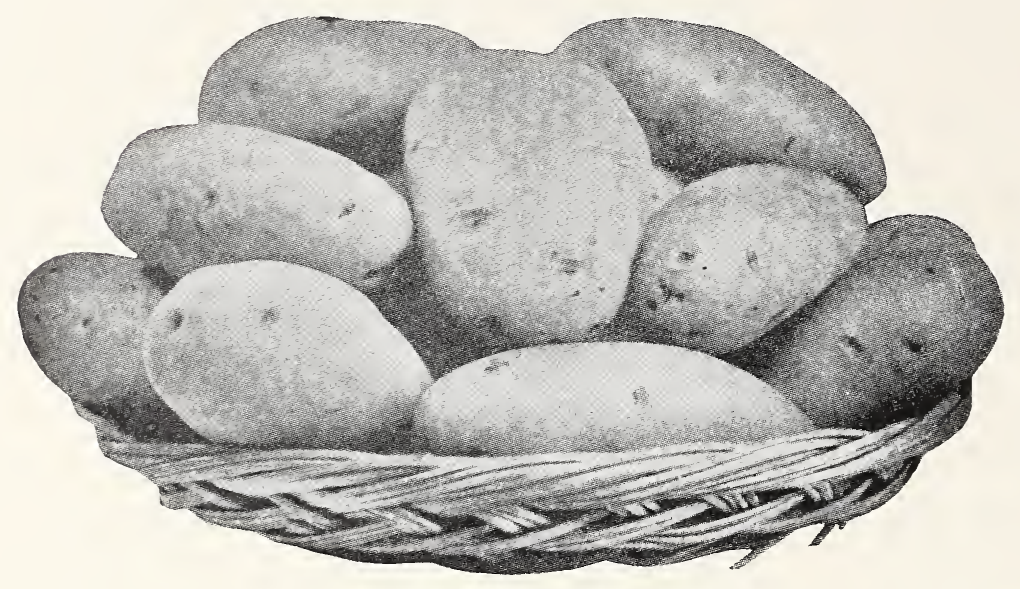

CERTIFIED SEED

Per $165 \mathrm{lb}$.

sack

Irish Cobbler .......\$8.00

Green Mountain... 8.00

Spaulding Rose... 8.00

All Either Maine or

Canadian Grown Seed

Certified Green Mountain

MAINE GROWN-Not Certified Seed

Irish Cobbler

$5 \mathrm{lb}$.

sack

Green Mountain

$\$ 7.00$

Early Northern

7.00

Early Rose

7.00

Spaulding Rose

7.00

Gold Coin

7.00

Carman

7.00

Sir Walter Raleigh

7.00

Red Bliss Triumph

7.00

Delaware

8.00

Russett

7.00

7.50

Write or Wire for delivered carload price.

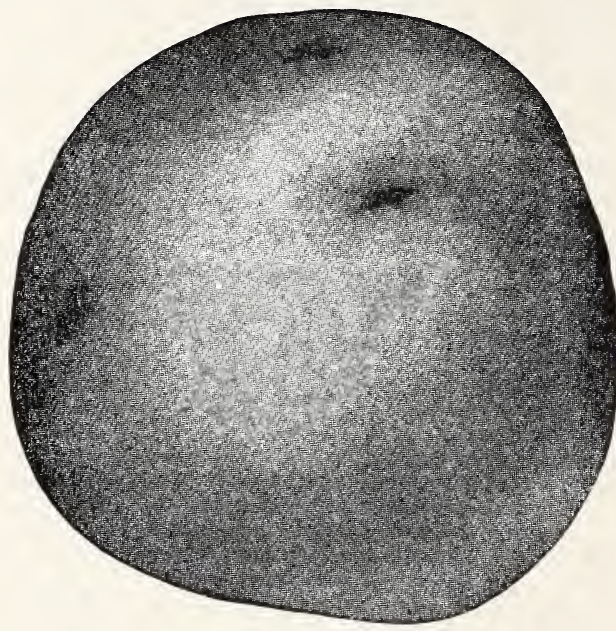

Red Bliss Triumph

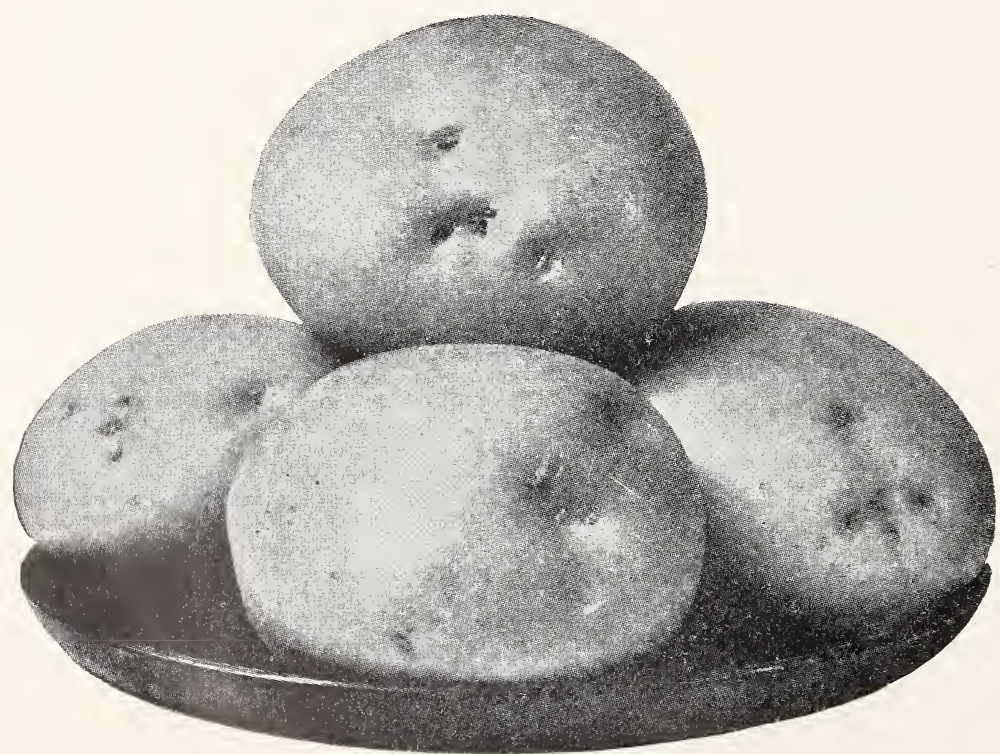

CERTIFIED SEED

IMPORTANT. We are glad to quote special prices on large lots of Seed Potatoes. Frequently we are able to make a close price on a carload of Potatoes to go to one section. Shall be glad to have our customers write us for prices.

On account of not sufficient quantities being grown we can only supply three varieties in Certified Stock-we urge you to use Certified Seed wherever possible.

Certified Irish Cobblers 


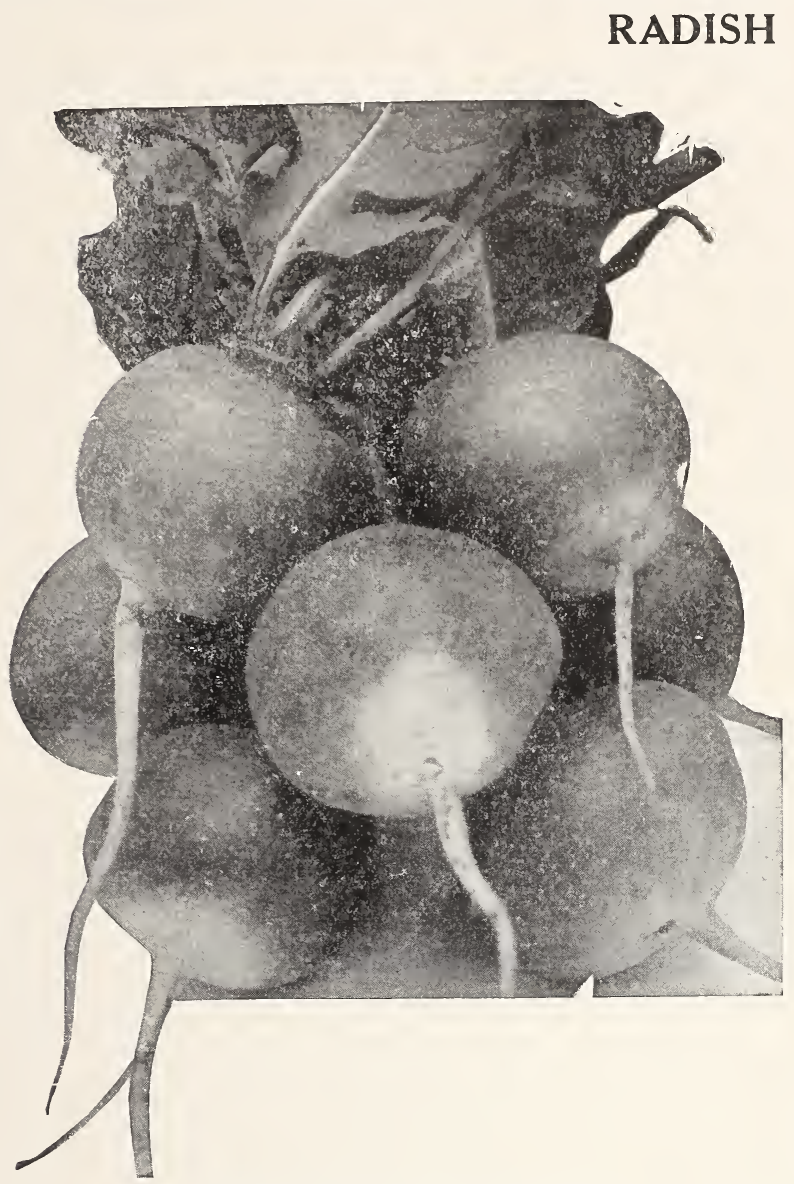

Special Sparkler White Tip
WOODRUFF'S SELECTED SCARLET GLOBEThe best General Purpose Variety as illustrated on Page 5 Specialties. Pkt., $10 \mathrm{c}$; oz., 15c; 1/4 lb., 30c; lb., $75 \mathrm{c} ; 50$ lbs., $60 \mathrm{c}$.

S P E C I A SPARKLER WHITE TIP-Of rich carmine-scarlet color, with a very pronounced tip of the purest white. The roots, even when fully developed, are solid, crisp and sweet, and remain fit for use as long as the coarser kinds. It is equally well adapted for forcing in frames or growing in the open ground. While the leaves are small, they are sufficiently large for bunching. Pkt., $10 \mathrm{c}$; oz., $15 \mathrm{c}$; $1 / 4$ lb., 25c; lb., 75c.

\section{NEW CRIMSON GIANT}

Extremely large, but never pithy. One of the best for out-door culture. The most showy Bunch and Crate Radish grown. Pkt., 10c; oz., $15 \mathrm{c} ; 1 / 4$ lb., $25 \mathrm{c} ; 1 \mathrm{lb} ., 75 \mathrm{c}$.

WHITE ICICLE - "The best all-round" Radish for all purposes in the home-garden; also fine for market, the roots attain a length of 4 to 5 inches by $3 / 4$ inch in diameter. It remains in fine table condition longer than any other early sort, regardless of shape. Pkt., 10c; oz., $15 \mathrm{c}$; 1/4 lb., 25c; lb., 75c.

\section{SUMMER VARIETIES}

All following varieties at uniform prices. Pkt., $10 \mathrm{c}$; oz., $15 \mathrm{c} ; 1 / 4 \mathrm{lb} ., 25 \mathrm{c} ; \mathrm{lb} ., 75 \mathrm{c} ; 10 \mathrm{lbs}$. or over at $70 \mathrm{c}$ per lb.; $50 \mathrm{lbs}$. or over at $60 \mathrm{c}$ per lb., either one or assorted.

\section{Scarlet Globe xx}

Early Deep Scarlet

Scarlet Turnip White Tipped

French Breakfast

White Summer Turnip

Early Long Scarlet Short Top

Cincinnati Market-Long Red

Chartier-Long Red White Tip

Long White Vienna

Giant White Stuttgart

Scarlet Turnip

Olive Shaped Scarlet

Golden Globe

White Strasburg

Philadelphia White Box

\section{WINTER VARIETIES}

Half-Long Black

Round Black Spanish or Fall

Long Black Spanish or Fall

China Rose or Winter

California Mammoth Winter

White Chinese or Celestial

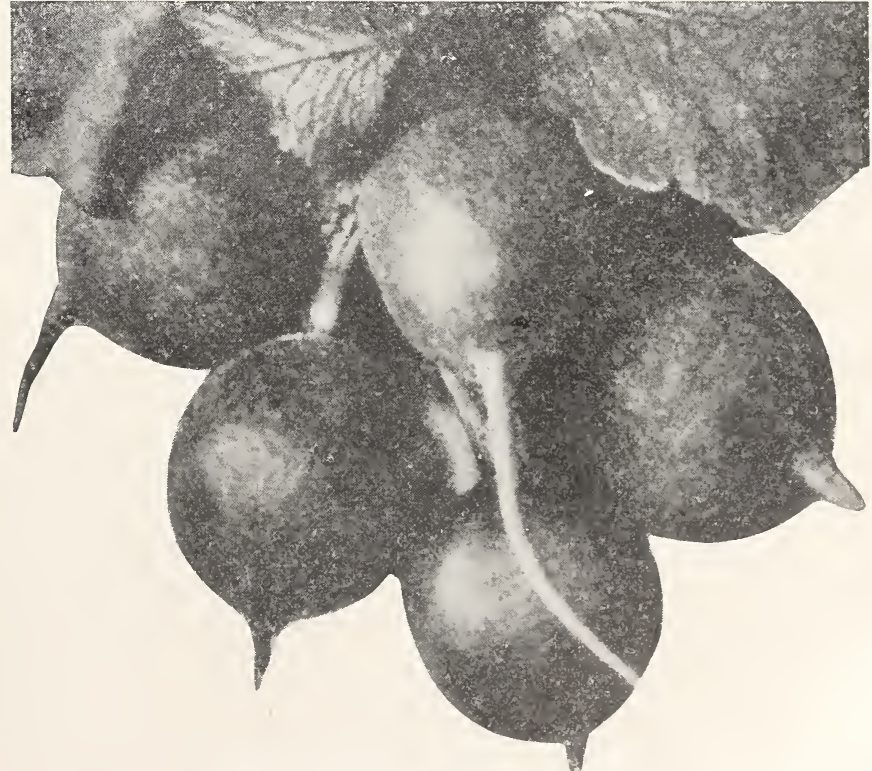

Woodruff's New Crimson Giant 


\section{SPINACH}

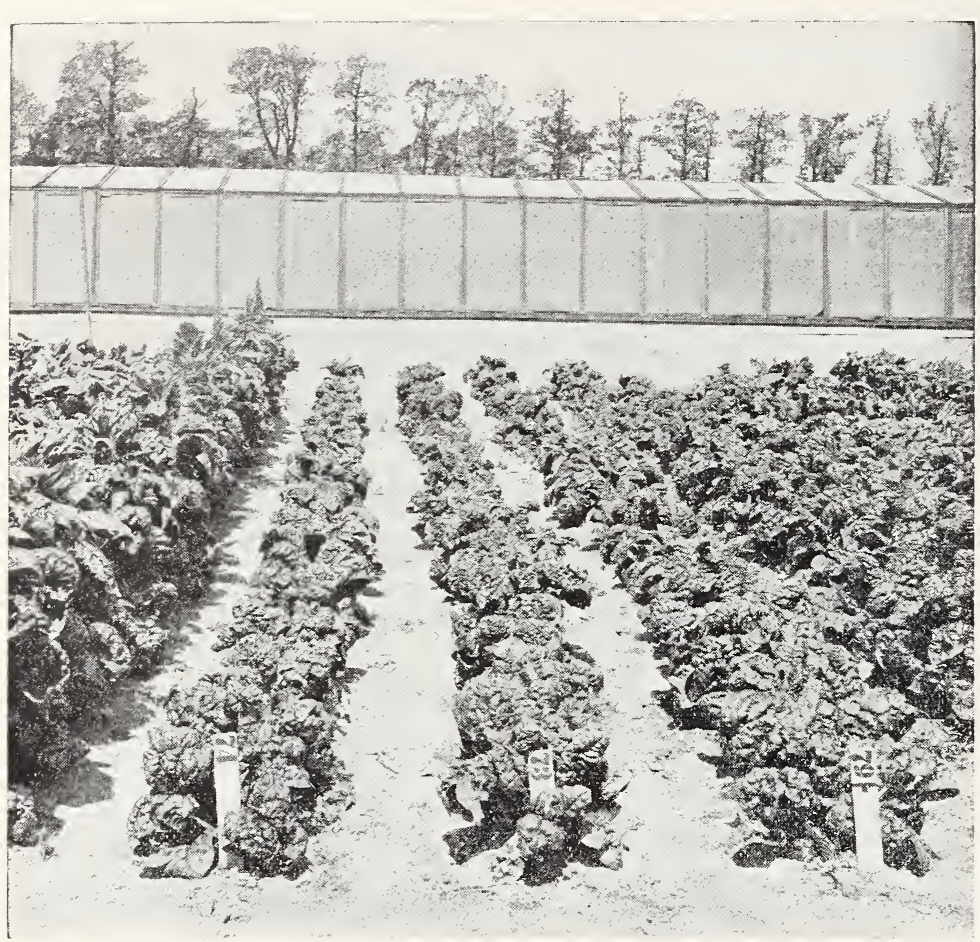

NEW LONG STANDING SAVOY - For description see Specialties Page 4.

Note three center rows in trial plot Long Standing Savoy Spinach planted at same date as Bloomsdale Savoy on either side. Stands at least one week longer without throwing seed stalks, a really remarkable feature. Pkt., $10 \mathrm{c} ;$ oz., $15 \mathrm{c} ; 1 / 4 \mathrm{lb}$, $25 \mathrm{c}$; lb., 40c; 100 lbs., $\$ 25.00$.

\section{NOBEL GIANT LEAVED}

- The largest-Flat Growing -L o ng Standing Spinach ever known. It is a plainleaf type like Viroflay but nearly double the size. Enormous yielder. Very attractive deep green color and will not shoot seed quickly. Pkt., 10c; oz., $15 \mathrm{c} ;{ }^{1 / 4} \mathrm{lb} ., 20 \mathrm{c}$; lb., $40 \mathrm{c}$; 100 lbs., $\$ 30.00$.

Trial-Plots of Long Standing Savoy

KING OF DENMARK - The leaves are large, rounded, somewhat blistered, and deep green. The plants grow vigorously and are ready to use as soon as any kind. Pkt., $10 \mathrm{c}$; 1/4 lb., 20c; lb., 40c; 100 lbs., $\$ 25.00$.

JULIANA - This is of the Long Season type, having a large, beautiful, crumpled leaf. It has that beautiful, rich dark green color and it will stand hot weather without bolting to seed longer than any other sort. Good for either Spring or Fall planting. Pkt., 10c; $1 / 4$ lb., 20c; lb., 40c; 100 lbs., $\$ 25.00$.

We offer the following standard varieties, all of the best stocks, at the following uniform prices: Oz., 10c; $1 / 4$ lb., 15c; lb., 40c; 10 lbs., lots at $25 \mathrm{c}$ per $\mathrm{lb}$.

BLOOMSDALE SAVOY.

ROUND THICK LEAF.

GIANT or MONSTROUS VIRO-

\section{FLAY.}

LONG STANDING.

LONG SEASON or TRIUMPH.

NEW ZEALAND - While not of the Spinach family, it is very popular because it produces an abundance of foliage. It is of vigorous growth, producing leaves throughout the entire summer, and is in no way affected by heat. Pkt., 10c; oz., 15c; 1/4 lb., $35 \mathrm{c} ; \mathrm{lb} ., 80 \mathrm{c}$.

\section{RESELECTED BLOOMSDALE SAVOY-}

An improvement over the old type bred for size. The plant is early and makes an immense spreading rosette which bushels wonderfully. The leaves are intensely blistered and crumpled and are a glossy deep green in color. Very desirable for early spring planting and for wintering over. Several days earlier than Long Standing Savoy.

Prices, pkt., 10c; 1/4 lb., 15c; lb., 35c; 100 lbs., $\$ 22.00$.

\section{SALSIFY}

MAMMOTH SANDWICH ISLAND-Roots grow long, large and smooth. Pkt., $10 \mathrm{c}$; $1 / 1$ lb., $75 \mathrm{c} ; 1 \mathrm{~b} ., \$ 2.50$.

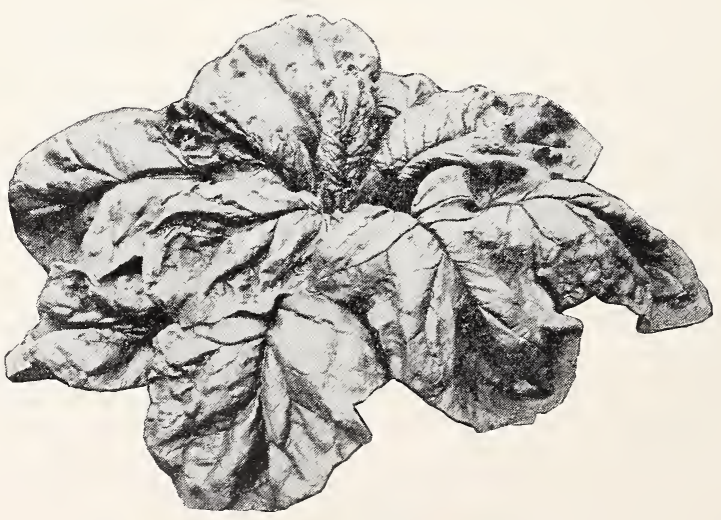

Nobel Giant Leafed Spinach 


\section{TOMATO}
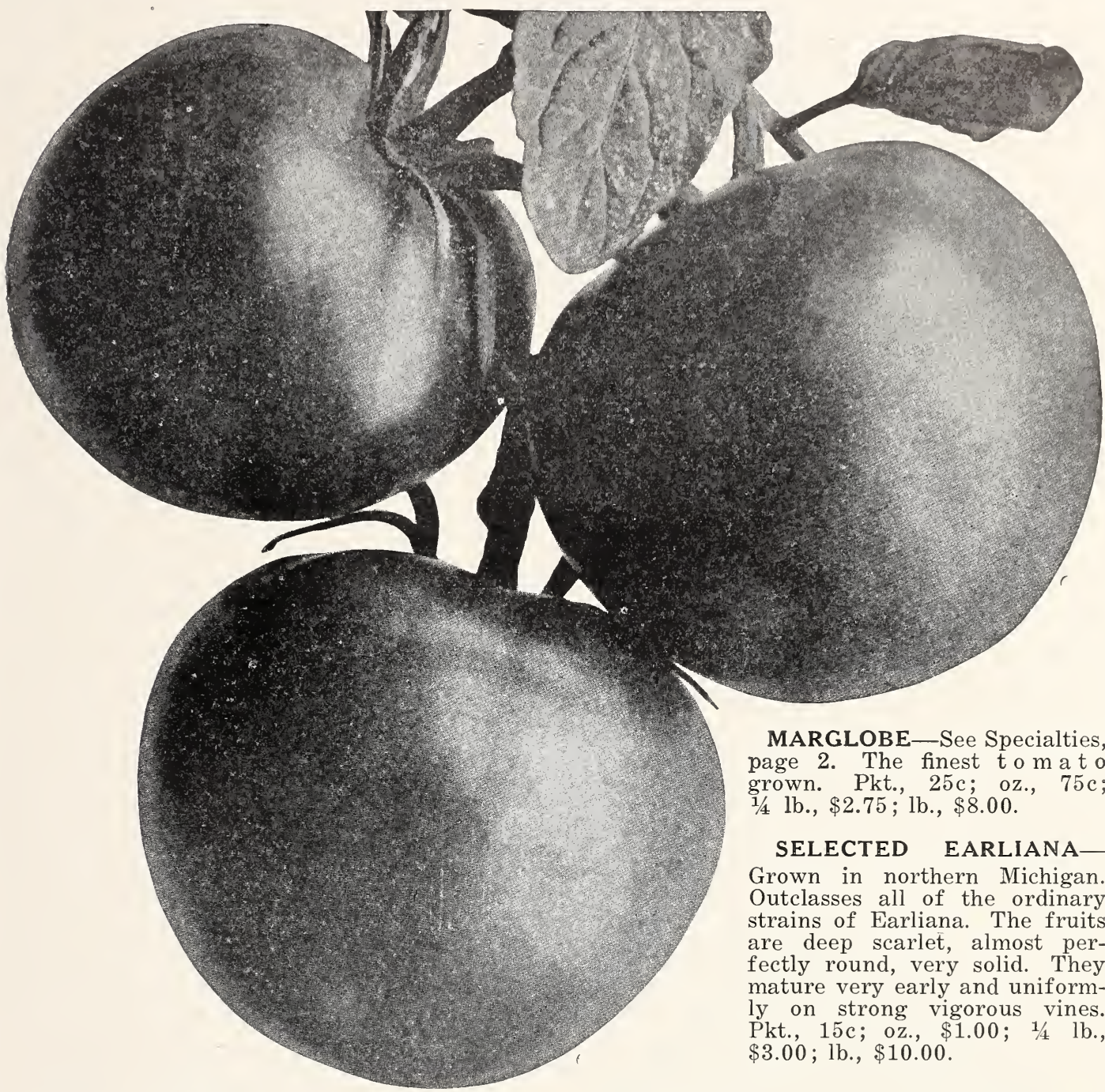

MARGLOBE-See Specialties, page 2. The finest $\mathrm{to} \mathrm{m}$ a t $\mathrm{o}$ grown. Pkt., 25c; oz., $75 \mathrm{c}$. $1 / 4$ lb., $\$ 2.75 ; 1 b ., \$ 8.00$.

\section{SELECTED EARLIANA-} Grown in northern Michigan. Outclasses all of the ordinary strains of Earliana. The fruits are deep scarlet, almost perfectly round, very solid. They mature very early and uniformly on strong vigorous vines. Pkt., $15 \mathrm{c} ;$ oz., $\$ 1.00 ; 1 / 4$ lb., $\$ 3.00$; lb., $\$ 10.00$.

EARLY AVON-A selected strain of Earliana, smooth fruit. One of the best of its class and a great yielder. It gets the first high price in the earliest market. Pkt., 25c; oz., $\$ 1.00$; $1 / 4.1 b ., \$ 2.00 ; 1 b ., \$ 5.00$.

BONNIE BEST - One of the best early varieties. Ripens a little later than Earliana, with bright red smooth fruit, ripening even and close up to the stem. It is one of the best all around tomatoes. Plet., 10c; oz., 40c; $1 / 4$ lb., $\$ 1.50 ;$ lb., $\$ 5.00$.

CHALK'S EARLY JEWEL-This makes a fine medium early and main crop sort. Bright red fruit, ripens even, is solid and ships well. Holds its size well throughout the season. Our strain of Chalk's Early Jewel can be depended upon. Pkt., 10c; oz., 35c; $1 / 4$ lb., $\$ 1.00$; lb., $\$ 3.50$.

NORTON-This is a wilt-resisting variety developed by the U. S. Department of Agriculture. Resembles Stone in every way. It resists wilt to a remarkable degree. Pkt., 10c; oz., $40 \mathrm{c} ; 1 / 4$ lb., $\$ 1.25 ; \mathrm{lb} ., \$ 4.00$.
Liberal packets of all the following varieties $10 \mathrm{c}$ each; 10 pkts., $75 \mathrm{c}$ postpaid.

\begin{tabular}{|c|c|c|c|}
\hline June Pink & $\begin{array}{r}\mathrm{Oz} . \\
.50\end{array}$ & $\begin{array}{l}1 / 4 \mathrm{lb} . \\
\$ 1.25\end{array}$ & $\begin{array}{c}1 \mathrm{~b} . \\
\$ 4.00\end{array}$ \\
\hline Greater Baltimore & .50 & 1.50 & 4.00 \\
\hline ohn Baer & .50 & 1.50 & 4.00 \\
\hline Dwarf Stone. & .40 & 1.25 & 3.00 \\
\hline Early Acme ..... & .30 & 1.00 & 3.00 \\
\hline Matchless & .30 & 1.00 & 3.00 \\
\hline Dwarf Champion & .40 & 1.25 & 4.00 \\
\hline 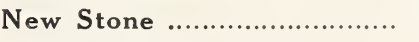 & .30 & 1.00 & 3.00 \\
\hline Livingston's Beauty & .30 & .80 & 3.00 \\
\hline Livingston's Perfection & .30 & .80 & 3.00 \\
\hline Livingston's Globe ....... & .50 & 1.25 & 3.00 \\
\hline Golden Queen & .3 & 1.00 & 3.50 \\
\hline Red $\mathrm{I}$ & .30 & 1.00 & 3.00 \\
\hline ond & .40 & 1.25 & 4.00 \\
\hline
\end{tabular}

Pickling varieties. All packets $10 \mathrm{c}$; oz., $50 \mathrm{c}$.

Yellow Plum, Red Plum, Yellow Cherry, Red Cherry, Yellow Pear, Red Pear,

Red Peach. 


\section{TURNIP}

RED TOP WHITE GLOBE TURNIP-Special hand selected and transplanted roots. Connecticut grown stock from our own Home Farm. A bright red top half way down the turnip. Beautiful uniform roots. Pkt., 10c; oz., 15c; 1/4 lb., 50c; lb., $\$ 1.50$.

Uniform prices on all varieties Turnips and Ruta Bagas. Pkt., 10c; oz., 15c; 1/4 lb., 30c; lb., 80c.

YELLOW ABERDEEN.

YELLOW or AMBER GLOBE-Excellent for table or stock.

WHITE EGG-Egg-shaped variety.

EARLY WHITE FLAT DUTCH.

EARLY WHITE STRAP LEAF.

EARLY RED TOP STRAP LEAF.

LARGE WHITE or COW HORN.

EXTRA EARLY PURPLE TOP MILAN.

EXTRA EARLY WHITE TOP MILAN.

POMERANIAN or LARGE WHITE GLOBE.

SEVEN TOP.

\section{RUTA BAGA \\ YELLOW FLESHED SORTS}

AMERICAN PURPLE TOP.

LONG ISLAND IMPROVED PURPLE TOP.

\section{WHITE FLESHED SORTS}

WHITE ROCK or BUDLONG.

WHITE FRENCH.

MACOMBER, New-Pkt., 10c; oz., 15c; 1/4 lb., 50c; lb., $\$ 1.50$.

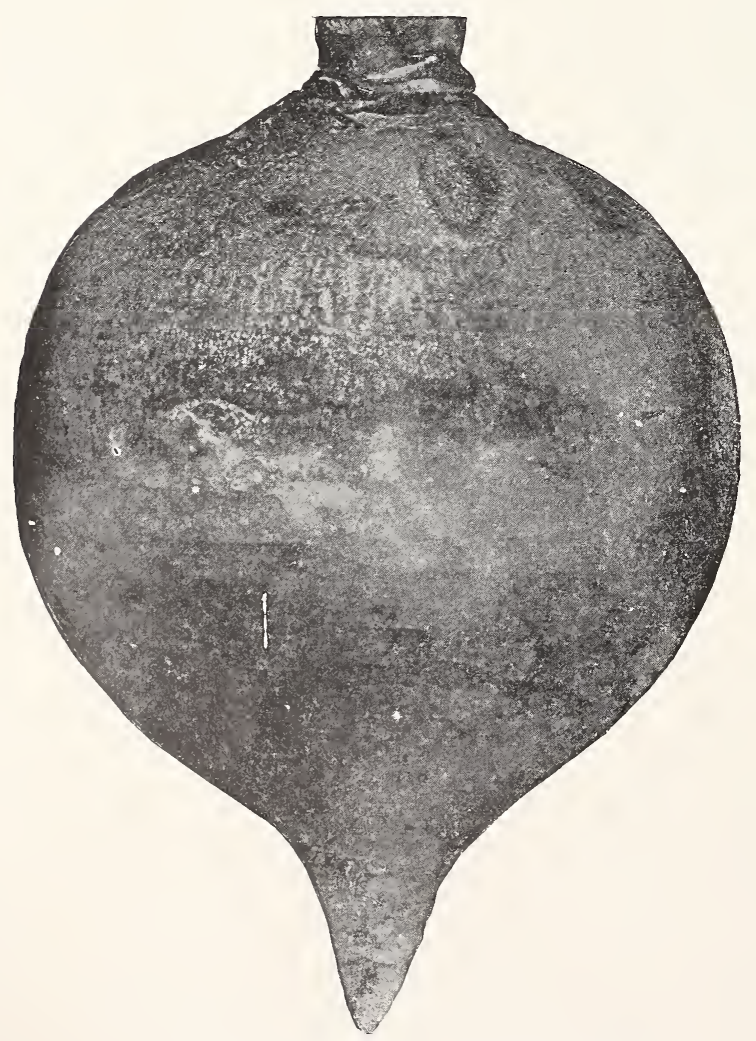

\section{OLD-FASHIONED MEDICAL HERBS}

Packets of each, 10c

Name of Seed. Oz. $1 / 4 \mathrm{lb}$.

ANISE-Seeds aromatic .......... $\$ .20 \$ .40$

BORAGE ............................. $.20 \quad .60$

BALM ................................. .40 1.00

BASIL_-Sweet for flavoring.... $.40 \quad 1.00$

CARAWAY_For flavoring..... $\quad .25 \quad 1.00$

CHERVIL_Double Curled....... $.40 \quad .75$

$\begin{array}{llll}\text { CORIANDER_For flavoring.... } & .20 & .75\end{array}$

$\begin{array}{llll}\text { DILL_Mammoth } \ldots \ldots \ldots \ldots \ldots \ldots \ldots & .20 & .50\end{array}$

FENNELL_Florence ............. .20 $\quad .75$

$\begin{array}{lllll}\text { LAVENDER-Fragrance ......... } & .40 & 1.50\end{array}$

MARJORAM-Sweet $\ldots \ldots \ldots \ldots \ldots . . . . . .40 \quad 1.25$

SAGE-Flavoring ................... $.50 \quad 1.25$

SUMMER SAVORY_Flavoring $\quad .40 \quad 1.25$

$\begin{array}{lll}\text { SORRELL . } & .25 & .60\end{array}$

THYME_French .................... .60 1.50

WORMWOOD-Medicinal ....... $\quad .40 \quad 1.00$ 
Woodruff's
Velvet Gree

Velvet Green
LAWN GRASS SEEDS

For Lawns, Parks, Tennis Courts and Golf Links
Makes

A Carpet

Of Grass

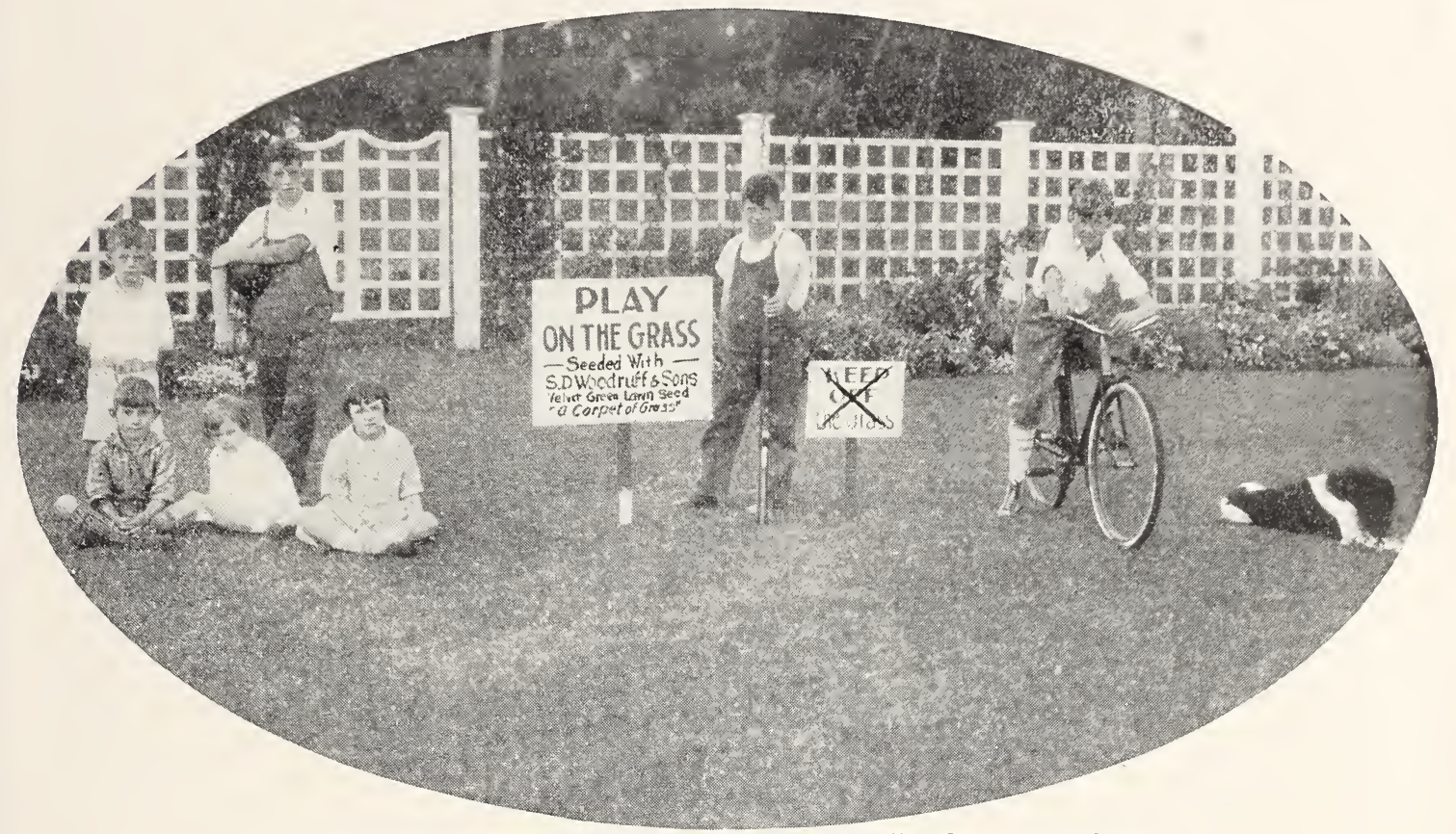

Woodruff's Velvet Green Lawn Seed makes "A Carpet of Grass"

\section{WOODRUFF'S VELVET GREEN LAWN SEED}

We head our list of lawn grass mixtures with this specially selected brand of seed. It has given many of our customers a satisfactory lawn and is the best mixture we can possibly offer. Quart carton, 40c; 5 lb. bag, $\$ 1.80 ; 100$ lbs., $\$ 35.00$.

\section{SHADY NOOK MIXTURE}

This mixture is designed for shady spots, where sufficient sun to grow the ordinary lawn mixtures does not reach. 100 lbs. to acre. Lb., 45c; 5 lb. bag, $\$ 2.00 ; 100$ lbs., $\$ 33.00$.

\section{FAIR GREEN MIXTURE}

Woodruff's Special Fairway mixture is used by many of the best golf courses in the Country. It is a quick growing mixture of specially blended grasses. 1 lb., $35 \mathrm{c}$; 5 lb. bag $\$ 2.00$; 100 lbs., $\$ 37.50$.

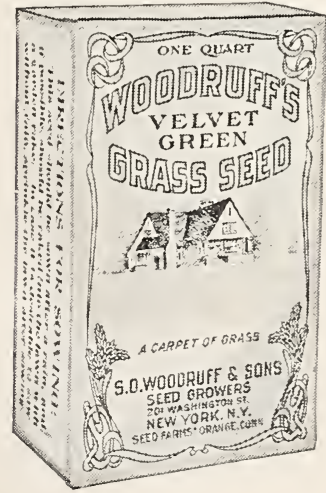
in Lawn Grass.

\section{WOODRUFF'S CENTRAL MIXTURE}

The Grasses used are selected with the purpose of producing a close turf of fine, even texture, which when once attained is permanent and beautiful. (Only the highest grade of Grasses used in this mixture.) 4 bushels to acre, 20 lbs. to bushel. Quart carton, $35 \mathrm{c} ; 5$ lb. bag, $\$ 1.60 ; 100$ lbs., $\$ 30.00$.

\section{TERRACE LAWN GRASS SEED}

The grasses used for a sloping bank or terrace must have such roots as will withstand the washing caused by heavy rains. This mixture forms a network of densely matted roots of deep-rooting character. These deep roots will better withstand the drought during the summer as they reach down below the surface dryness. 1 lb. $45 \mathrm{c} ; 5 \mathrm{lb}$. bag, $\$ 2.00 ; 100 \mathrm{lbs}$., $\$ 35.00$.

\section{SPECIAL MIXTURES FOR SPECIAL PURPOSES}

If our customers will write us, giving the nature and condition of the soil to be treated, we will make up a special mixture that will suit the purpose, in any locality or climate.

\section{CREEPING BENT STOLONS}

We can also supply these Stolons or Plants which will produce a wonderful Lawn exactly the same as a Golf Putting Green in about six weeks time. We grow these at Orange, Conn. Write us for prices if you are contemplating a new lawn-Creeping Bent is the last word

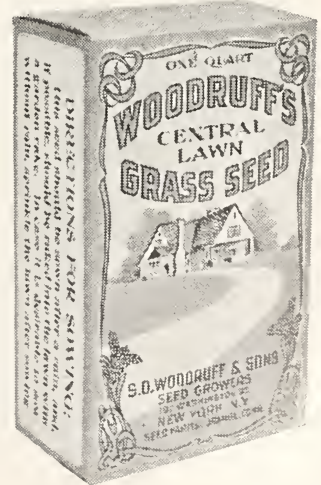




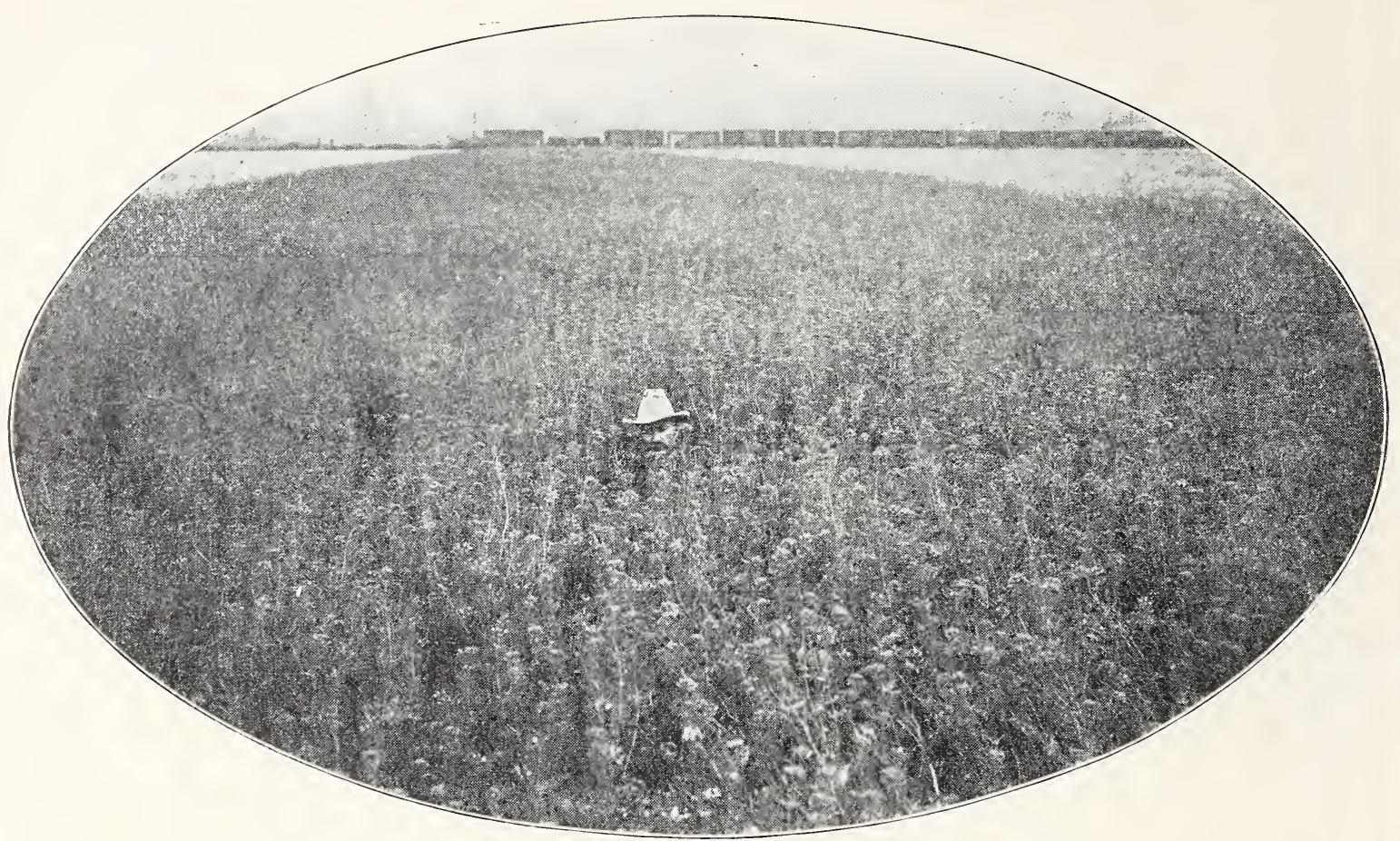

Typical Picture of One of Our Many Seed Farms

\section{GENERAL LIST OF GRASS AND FARM SEEDS}

CREEPING BENT-Lb., $\$ 1.00 ; 100$ lbs., $\$ 90.00$.

FANCY RED TOP-Lb., 30c; 100 lbs., $\$ 25.00$.

MEADOW FOXTAIL GRASS-Lb., 40c; 100 lbs., $\$ 30.00$.

SWEET VERNAL (Annual)-Lb., 40c ; 100 lbs., $\$ 35.00$

CRESTED DOG'S TAIL - Lb., 40c; 100 lbs., $\$ 30.00$.

ORCHARD GRASS-Lb., 35c; bu. of 14 lbs., $\$ 3.00$.

RED FESCUE-Lb., 50c; 100 lbs., $\$ 45.00$ SHEEP FESCUE - Lb., 50c; 100 lbs., $\$ 35.00$.

MEADOW FESCUE-Lb., 40c; $100 \mathrm{lbs}$. $\$ 35.00$.

\section{FIELD OR COW PEAS}

THE GREAT SOIL IMPROVER

BLACK COW PEAS-Pk., $\$ 1.25$; bu., $\$ 4.50$. WHIPPOOR WIL.L-Pk., $\$ 1.25 ; \mathrm{bu} ., \$ 4.50$. SOJA BEANS-Pk., $\$ 1.35$; bu., 4.25. Quantity required per acre, 2 bushels.

CANADA FIELD PEAS-Pk., \$1.50; bu.,

$\$ 3.75 ; 10$ bu. lots at $\$ 3.50$ per bu.

SPRING RYE-Pk., $\$ 1.00 ;$ bu., $\$ 3.00$.

FALL or WINTER RYE - Pk., 90c; bu., $\$ 2.50$.

WINTER VETCH-Lb., 45c; 10 lbs., 30c; 100 lbs., $\$ 20.00$.

\section{SEED OATS}

LINCOLN-Bu., $\$ 1.50 ; 10$ bus. and over, $\$ 1.35$.

WHITE RUSSIAN - Bu., $\$ 1.50 ; 10$ bus. and over, $\$ 1.35$.

SWEDISH SELECT-Bu., $\$ 1.50 ; 10$ bus. and over, $\$ 1.35$

BUMPER CROP_-Bu., $\$ 1.50 ; 10$ bus. and over at $\$ 1.35$ per bu.
ITALIAN RYE GRASS-Lb., 18c; 100 lbs., $\$ 14.00$.

HUNGARIAN MILLET-Lb., 12c; $100 \mathrm{lbs.}$, $\$ 8.00$.

GOLDEN MILLET - Lb., 12c; 100 lbs., $\$ 7.00$

JAPANESE MILLET-Lb., 25c; 100 lbs., $\$ 8.00$.

TIMOTHY (Phleum pratense)-Lb., 15c; 100 lbs., \$8.00.

KENTUCKY BLUE GRASS (Poa pratensis )-Lb., $40 \mathrm{c} ; 100$ lbs., $\$ 32.00$.

RED CLOVER - Domestic Northern grown.

Lb., 40c; 100 lbs., $\$ 32.00$.

MAMMOTH RED CLOVER-Lb., 50c; 100 lbs, $\$ 35.00$.

CRIMSON CLOVER-Lb., 30c; $100 \mathrm{lbs}$, $\$ 20.00$.

ALSIKE CLOVER - Lb., 45c; 100 lbs., $\$ 30.00$.

WHITE CLOVER (Trifolium repens)-Lb., $60 \mathrm{c} ; 100$ lbs., $\$ 45.00$.

ALFALFA or LUCERNE - Lb., 40c; 100 lbs., $\$ 35.00$.

GRIMM ALFALFA-Lb., 60c; 100 lbs., $\$ 45.00$.

SWEET CLOVER or WHITE BLOSSOMLb., 30c; 10 lbs., $\$ 2.20 ; 100$ lbs., $\$ 18.00$.

BUCKWHEAT

JAPANESE BUCKWHEAT-Lb., 25c; 100 lbs., $\$ 6.50$.

\section{WINTER WHEAT}

RED-Pk., $\$ 1.00 ;$ bu., $\$ 3.00$.

WHITE-Pk., $\$ 1.00$; bu., $\$ 3.00$.

SPRING WHEAT-Pk., 90c; bu., \$3.00.

DWARF ESSEX RAPE-Lb., 20c; $10 \mathrm{lbs}$. at $18 \mathrm{c} ; 100$ lbs., $\$ 15.00$.

BARLEY-Hulless. Bu., $\$ 3.00 ; 5$-bu. lots, $\$ 2.50$ per bu.

BARLEY (6 Row)-Bu., $\$ 2.50 ; 5$ bu. lots, $\$ 2.25$. 


\section{FLOWER SEEDS}

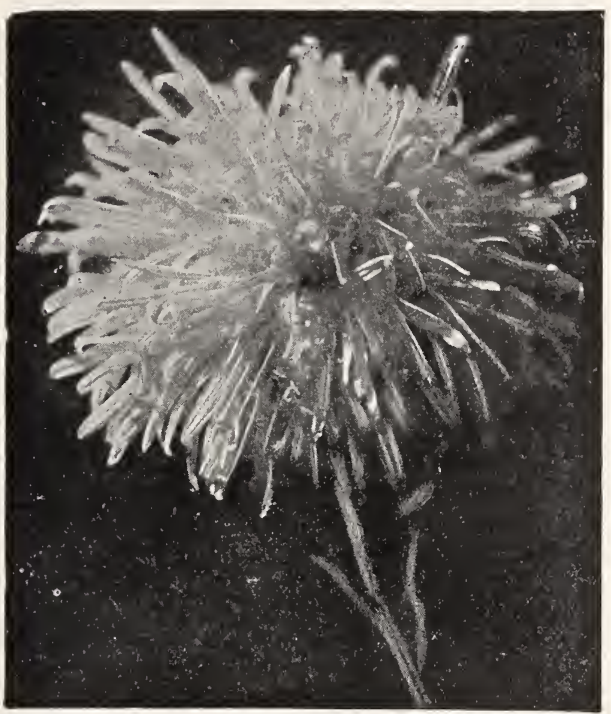

Semple's Branching Aster

The Best of the Old and New Varieties ACROLINIUM (Everlasting) - Height 15 inches.

Mixed-Pkt., 10c; oz., $25 \mathrm{c}$.

AGERATUM.

Mexicanum, blue white-Pkt., $10 \mathrm{c} ;$ oz., $40 \mathrm{c}$.

Dwarf Blue Tom Thumb-Pkt., 10c; oz., $50 \mathrm{c}$. ALYSSUM, SWEET.

Little Gem-Hardy annual. Pkt., 10c; oz., 30c. AMARANTHUS, tricolor-H. A. Plkt., 10c; oz., 40c.

Globe Amaranthus-Pkt., 5c; oz., 40c.

ANTIRRHIUM (Snapdragon)-Pkt., 10c ; oz., $60 \mathrm{c}$.

ASPARAGUS Sprengeri-4-6 feet. Pkt., $10 \mathrm{c} ;$ oz., $80 \mathrm{c}$.

\section{ASTERS}

QUEEN OF THE MARKET - Best early Aster in cultivation. 1 foot. Pkt., 10c; oz., $80 \mathrm{c}$.

TRUFFAUT'S PEONY-FLOWERED-Flowers very large, from 3 to 4 inches in diameter. Pkt., 10c;oz., $\$ 1.50$.

\section{SEMPLE'S LATE BRANCHING}

Light Pink.

Flesh Pink.

Lavender.

Dark Red.

Each of the above pkts. $10 \mathrm{c}$; oz., $80 \mathrm{c}$.

VICTORIA.

Separate Color-Pkt., 10c; oz., \$1.25.

Mixed-Pkt., 10c; oz., \$1.25.

GIANT COMET or POODLE.

White-Pkt., 10c; oz., 80c.

Mixed-Pkt., 10c; oz., $\$ 1.00$.

BALSAM-Known as Lady Slipper. Hardy annual. 18 inches high.

Double Dwarf Mixed-Pkt., 10c; oz., 60c.

Double Tall Mixed-Pkt., 10c; oz., 60c.

CALLIOPSIS or Coreopsis-Finest mixed.

Pkt., 5c; oz., 20c.

\section{CANDYTUFT.}

White-Pkt., 10c; oz., 20c.

Fine Mixed-Pkt., 10c; oz., 30c.
CANNA, Fine Mixed-Pkt., 10c; oz., 20c. CANTERBURY BELLS.

Single Mixed-Pkt., 10c; oz., 50c.

Double Mixed-Pkt., $10 \mathrm{c} ; \mathrm{oz} ., 75 \mathrm{c}$.

CARNATION-Half hardy perennial. $1 \frac{1}{2}$ feet.

Double Mixed-Pkt., 10c; oz., $\$ 2.00$.

CASTOR BEAN or Ricinus-Tall, majestic plants for lawns 6 to 15 feet high. Pkt., 10c; oz., 30c.

CELOSIA or Coxcomb-Free blooming.

Dwarf Double Mixed-Pkt., 10c; oz., $\$ 1.25$.

CENTAUREA Cyanus (Bachelor's Button) -Pkt., 10c; oz., 50c.

Cyanus, Double-Pkt., 10c; oz., 35c.

COLUMBINE (Aquilegia).

Mixed-Pkt., 10c; oz., \$1.25.

California Hybrid-Pkt., $10 \mathrm{c}$; oz., $\$ 2.00$.

CONVOLVULUS major (Morning Glory)

Finest Mixed-Pkt., 10c; oz., $15 \mathrm{c}$; lb., 60c.

Minor, Dwarf, Finest Mixed, 18 inches-Pkt., $10 \mathrm{c} ;$ oz., $15 \mathrm{c} ; \mathrm{lb} ., 60 \mathrm{c}$.

COSMOS -3 to 7 feet.

Early-flowering Dawn-Pkt., 10c; oz., 25c.

Giant Flowering, Mixed-Pkt., $10 \mathrm{c}$; oz., $50 \mathrm{c}$.

DAHLIA, Single Mixed-Pkt., $10 \mathrm{c}$; oz., $60 \mathrm{c}$.

Finest Double Mixed-Pkt., $10 \mathrm{c}$; oz., $\$ 1.00$.

DAISY, Double White, alba fi, pl.-Pkt., $10 \mathrm{c}$; oz., $\$ 1.00$

Double Mixed-Pkt., $10 \mathrm{c} ;$ oz., $\$ 1.00$.

Shasta. H. P. Very large, white flowers. 3

feet.-Pkt., $10 \mathrm{c}$; oz., $\$ 2.00$.

DIANTHUS (Garden Pink)-H. P.

Chinese and Japanese Pinks

Chinensis. China Pink, double mixed.-Pkt. 10c; oz., 40c.

Heddewegii Finest Single Mixed-Pkt., 10c; oz., $40 \mathrm{c}$.

DIGITALIS (Foxglove).

Mixed-Pkt., 10c; oz., 40c.

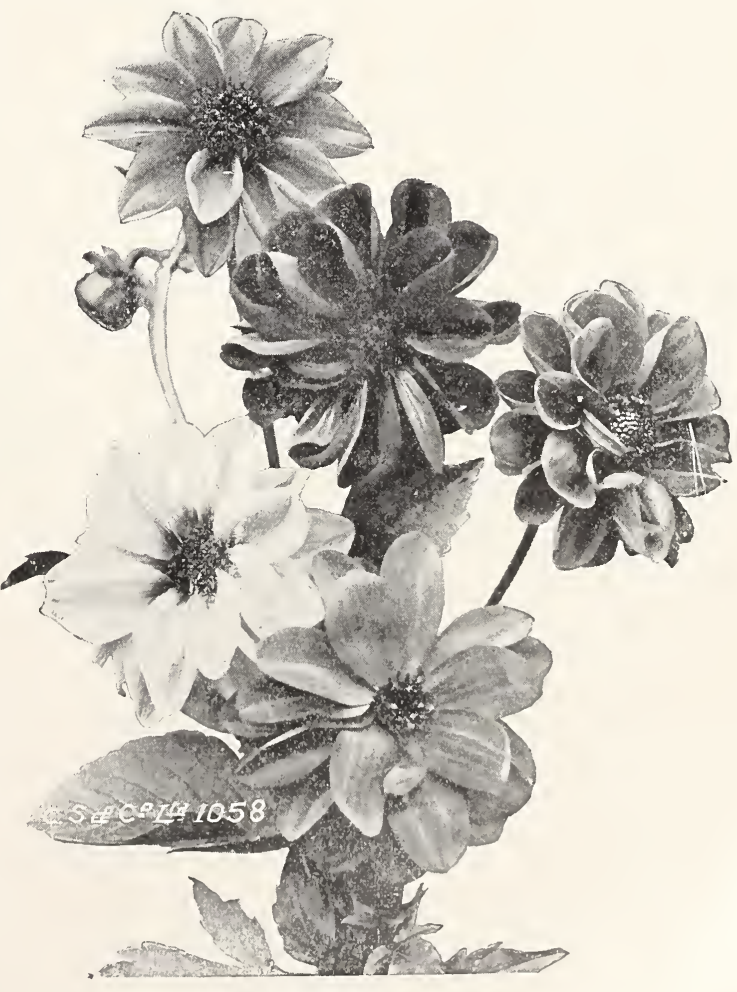

Dahlia Seedling 


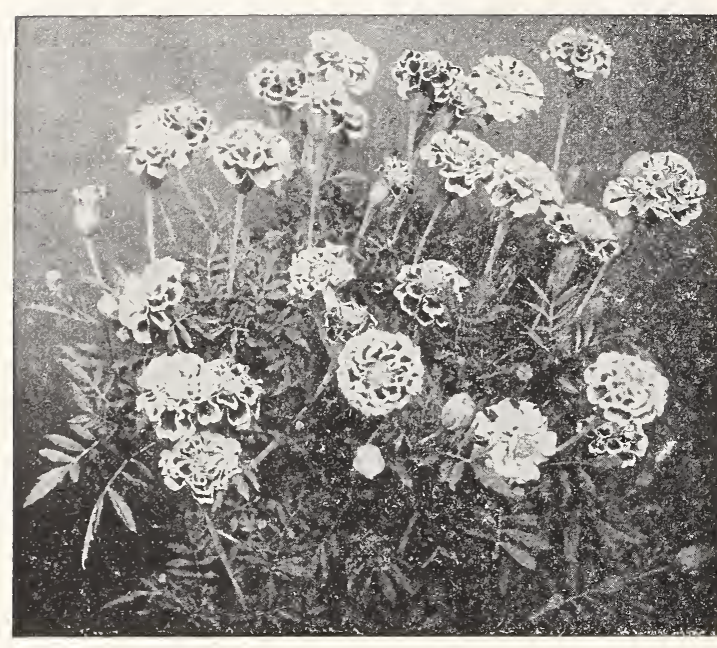

Marigold

ESCHSCHOLTZIA (California Poppy).

Deep Yellow-Pkt., 10c; oz., 20c.

Double White -Pkt., 10c; oz., 70c.

Choice Mixed, first quality-Pkt., 10c; oz., $25 \mathrm{c}$.

\section{GAILLARDIA.}

Single Mixed-Pkt., 10c; oz., $25 \mathrm{c}$. GILIA.

Mixed-Pkt., 10c; oz., 40c.

GODETIA (Satin Flower)-Pkt., 10c; oz., $40 c$

GYPSOPHILA-Pkt., 10c; oz., 35c.

HELICHRYSUM (Everlasting) - Pkt., 10c; oz., 35c.

HELIOTROPE.

Fines't Mixed, 2 feet-Pkt., 10c; oz., $\$ 1.50$

HIBISCUS (Mallow)-Pkt., 10c; oz., $25 \mathrm{c}$. HOLLYHOCK, Double.

Deep Rose

Pink.

Lemon Yellow.

Pkt., 10c; oz., $\$ 1.80$.

Choice Mixed-Pkt., $10 \mathrm{c} ;$ oz., $\$ 1.80$.

HUMULUS (Japanese Hop) - Pkt., 10c; oz., $15 \mathrm{c}$.

ICE PLANT 1 foot-Pkt., 10c; oz., $75 \mathrm{c}$.

IPOMOEA-H. A. Climber.

Purpurea (Morning Glory) - Pkt., 10c; oz., $20 \mathrm{c}$.

Bona-nox (Evening Glory) - Pkt., 10c; oz., $20 \mathrm{c}$.

Coccinea (Star Ipomoea)-Pkt., 10c; oz., 20c. Setosa (Brazilian Morning Glory) - Pkt., 10c oz., $25 \mathrm{c}$.

Fringed, Japanese-Pkt., 10c; oz., 25c. $40 \mathrm{c}$.

JOB'S TEARS. $1 \frac{1}{2}$ feet-Pkt., $10 c ; 0 z$.

LANTANA hybrids-Plkt., 10c; oz., 40c.

LARKSPUR. H. A.

Delphinium-Pkt., $10 \mathrm{c}$; oz., 40c.

Double Dwarf Rocket, Mixed-Pkt., 10c; oz., 40 c.

LOBELIA-Pkt., $10 \mathrm{c}$; oz., $\$ 1.00$.

LOVE-IN-A-MIST-Pkt., 10c; oz., 35c.

LUPIN-Pkt., $10 \mathrm{c}$; oz., $20 \mathrm{c}$.

LYCHNIS. H. P. $1 \frac{1 / 2}{2}$ feet-Pkt., $10 \mathrm{c}$; oz., $35 \mathrm{c}$

MARIGOLD_Old favorite of easy culture. H. A.

Meteor-Pkt., 10c; oz., 25c

Prince of Orange-Pkt., $10 \mathrm{c}$; oz., $25 \mathrm{c}$.

African El Dorado, Double - Pkt., 10c; oz., $30 \mathrm{c}$.

French Legion of Honour-Pkt., 10c; oz., 25c.

Little Brownie-Pkt., 10c; oz., 25c.
MAURANDYA, 3 feet.

Finest Mixed-Pkt., 10c; oz., $\$ 2.00$.

MARVEL OF PERU (Four O'Clock) - Pkt., $10 \mathrm{c}$; oz., 30c.

MARGUERITE-Pkt., $10 \mathrm{c} ;$ oz., $\$ 1.50$.

MIGNONETTE-Very easy to cultivate.

Large-flowering-Pkt., $10 \mathrm{c}$; oz., $50 \mathrm{c}$.

Machet (Red Tint) -Pkt., 10c; oz., 50c.

Allen's Defiance-Pkt., 10c; oz., $50 \mathrm{c}$.

Golden Queen-Pkt., 10c; oz., 50c.

MIMULUS-Pkt., $10 \mathrm{c}$; oz., $\$ 1.60$.

MONKEY FLOWER. H. A.-Pkt., $10 \mathrm{c}$; oz., $\$ 1.60$.

MOONFLOWER, Giant White-Pkt., 10c; oz., $75 \mathrm{c}$.

MORNING GLORY-See Convovulus.

MOURNING BRIDE (Scabiosa)-H. A.

Tall Mixed-Pkt., 10c; oz., 60c.

Dwarf Mixed-Pkt., 10c; oz., 30c.

MYOSOTIS (Forget-Me-Not)-H. P. Blue. Pkt., 10c; oz., 60c.

\section{NASTURTIUMS}

Tom Trumb, Choice Mixed - All the best dwarf sorts.-Pkt., 10c; oz., 20c; lb., \$1.00. Dwarf Variefated, Mixed-This is a fine mixture of the above, and many other select varieties.-Pkt., 10c; oz., 20c; lb., $\$ 1.00$.

Tall Choice Mixed-Pkt., 10c; oz., 20c.

Tall Variegated, Mixed-A very showy mixture.-Pkt., 10c; oz., 20c; $1 / 4$ lb., $35 \mathrm{c} ; 1 \mathrm{~b}$., $\$ 1.00$.

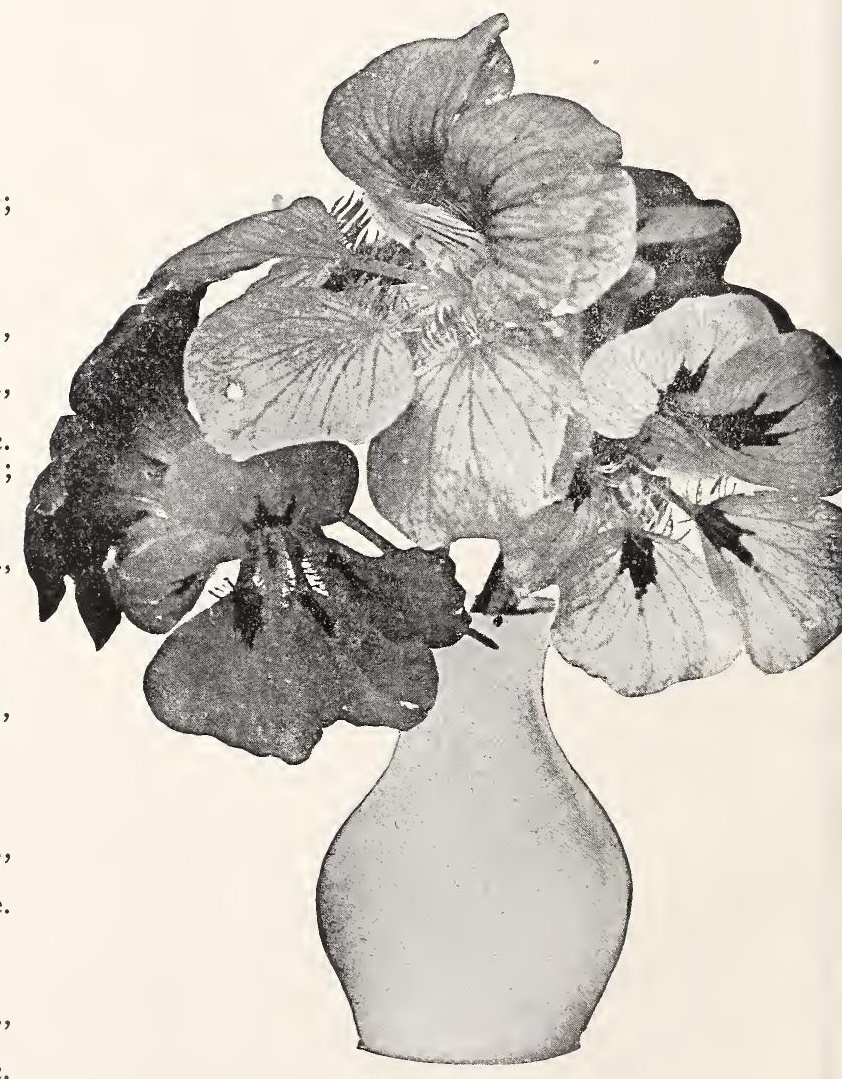

Nasturtiums 


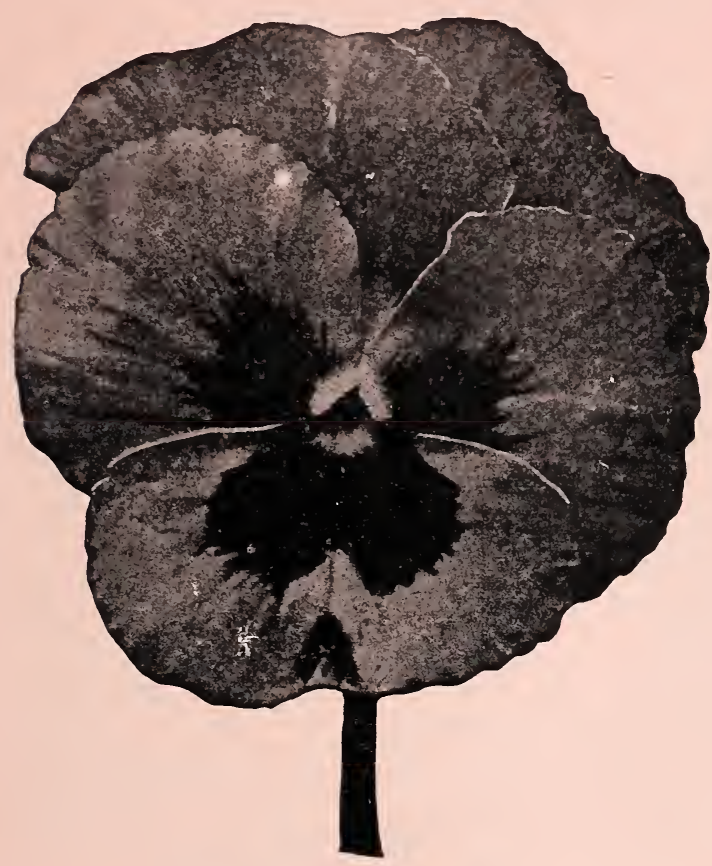

Parisian Giant Pansy

\section{PANSY}

\section{LARGE FLOWERING.}

King of the Blacks-Pkt., 10c; oz., $\$ 1.50$.

Meteor-Pkt., 10c; oz., $\$ 1.50$.

Choice Mixed-Pkt., $10 \mathrm{c} ;$ oz., $\$ 1.50$.

GIANT TRIMARDEAU.

Mixed-Pkt., 10c; oz., $\$ 2.00$.

PARISIAN MIXED. Giant flowered.-Pkt., $15 \mathrm{c} ;$ oz., $\$ 3.00$.

GIANT FLOWERING, Extra Choice Mixed. -Pkt., 15c; oz., $\$ 2.50$.

\section{PETUNIA.}

Striped and Blotched-Pkt., 10c; oz., $\$ 1.00$.

Fine Mixed-Pkt., 10c; oz., 75c.

Choice Mixed-Pkt., 10c; oz., $\$ 2.00$.

\section{PHLOX DRUMMONDI.}

\section{Large-flowering.}

Lilac-Pkt., 10c; oz., $\$ 1.00$.

Rose. With distinct eye.-Pkt., $10 \mathrm{c} ;$ oz., $\$ 1.00$.

Extra Choice Mixed-Pkt., 10c; oz., $\$ 1.00$.

\section{POPPY.}

Shirley, Fine Mixed-Pkt., 10c; oz., $20 c$.

Cardinal, Double Mixed-Pkt., 10c; oz., 30c.

Peony-flowered, Double Mixed-Pkt., 10c; oz.,

30c.

Orientale. Dark red-Pkt., 10c; oz., 80c.

PORTULACA. Half-hardy annual.

\section{Single Large-flowered.}

Albua-pura-Pkt., 10c; oz., 80c.

Aurea-Pkt., $10 \mathrm{c}$; oz., $80 \mathrm{c}$.

Fine Mixed-Pkt., $5 c$; oz., 60c.

Double, Tall-Pkt., 10c; oz., 20c.

Single Large-flowered, Fine Mixed-Pkt., 5c; oz., 60c.
PRIMROSE, EVENING-Pkt., i 0c; oz., 30c. ...PYRETHRUM. 2 to 3 feet.-Pkt., $10 \mathrm{c} ; \mathrm{oz}$. $\$ 1.00$.

RHODANTHE, Mixed-Pkt., 10c; oz., 50c.

SALPIGLOSSIS, Fine Hybrids Mixed-Pkt., 10c; oz., $\$ 1.00$.

SALVIA. 2 feet.

Splendens (Flowering Sage)-Pkt., 10c; oz., 80c.

SMILAX Myrisphyllum-Pkt., 10c; oz., 80c. SNAPDRAGON-See Antirrhinum $20 \mathrm{c}$.

SUNFLOWER, Tall, Single-Plkt, 10c; oz.,

Globosus fistulosus, Double, Tall-Pkt., 10c; oz., 20c.

SWEET WILLIAM (Dianthus barbatus).

Pure White-Pkt., 10c; oz., 50c.

Single Fine Mixed-Pkt., 10c; oz., 30c.

Double Mixed, Extra-Pkt., 10c; oz., 80c.

\section{VERBENA}

Fine Mixed-Pkt., $10 \mathrm{c}$; oz., $80 \mathrm{c}$.

Blue-Pkt., 10c; oz., 80c.

Defiance. Scarlet-Pkt., 10c; oz., $\$ 1.00$.

Pure White, Large-Pkt., 10c; oz., $\$ 1.50$.

Mammoth Mixed-Pkt., 10c; oz., \$1.50.

\section{WALLFLOWER}

Harbinger brown-Pkt., 10c; oz., 40c.

Mixed Double-Pkt., $10 \mathrm{c}$; oz., $\$ 2.50$.

\section{ZINNIA}

Double Dahlia-Flowered Big Type.

A beautiful new type closely resembling decorative dahlias in form and in the arrangement of the petals. They attain a height of 3 feet, producing large blooms of distinctive colorings as follows:

Canary Bird-Primrose.

Crimson Monarch-Red.

Dream-Purple.

Golden State-Orange.

Meteor-Deep red.

Old Rose.

Polar Bear-White.

Scarlet Flame.

Pkt., 10c; each (or 1 packet of the 8 named sorts for 50c); $1 / 4$ oz., $\$ 1.50 ;$ oz., $\$ 5.00$. Mixed colors: Pkt., $10 \mathrm{c} ; 1 / 4$ oz., $65 \mathrm{c} ; 0 \mathrm{z} ., \$ 2.00$.

\section{CALIFORNIA GIANT ZINNIAS}

A greatly improved Zinnia frequently reaching 5 to 6 inches in diameter on large, strong plants 2 feet high. In a splendid range of separate colors. Scarlet, Salmon, Golden Yellow, Rose, Crimson, White, Violet, and Shrimp Pink at $10 \mathrm{c}$ per pkt. ( or 1 packet each of the 8 colors for 50c); $1 / 4$ oz., 50c; oz., $\$ 1.50$.

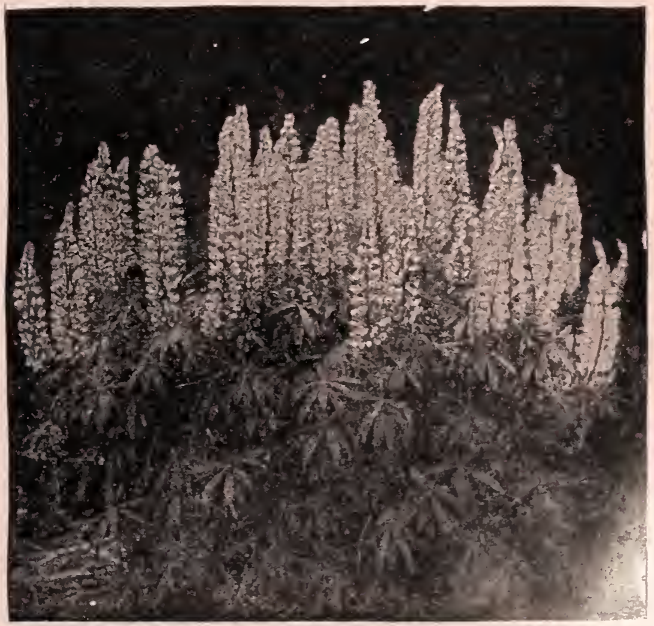

Lupin 


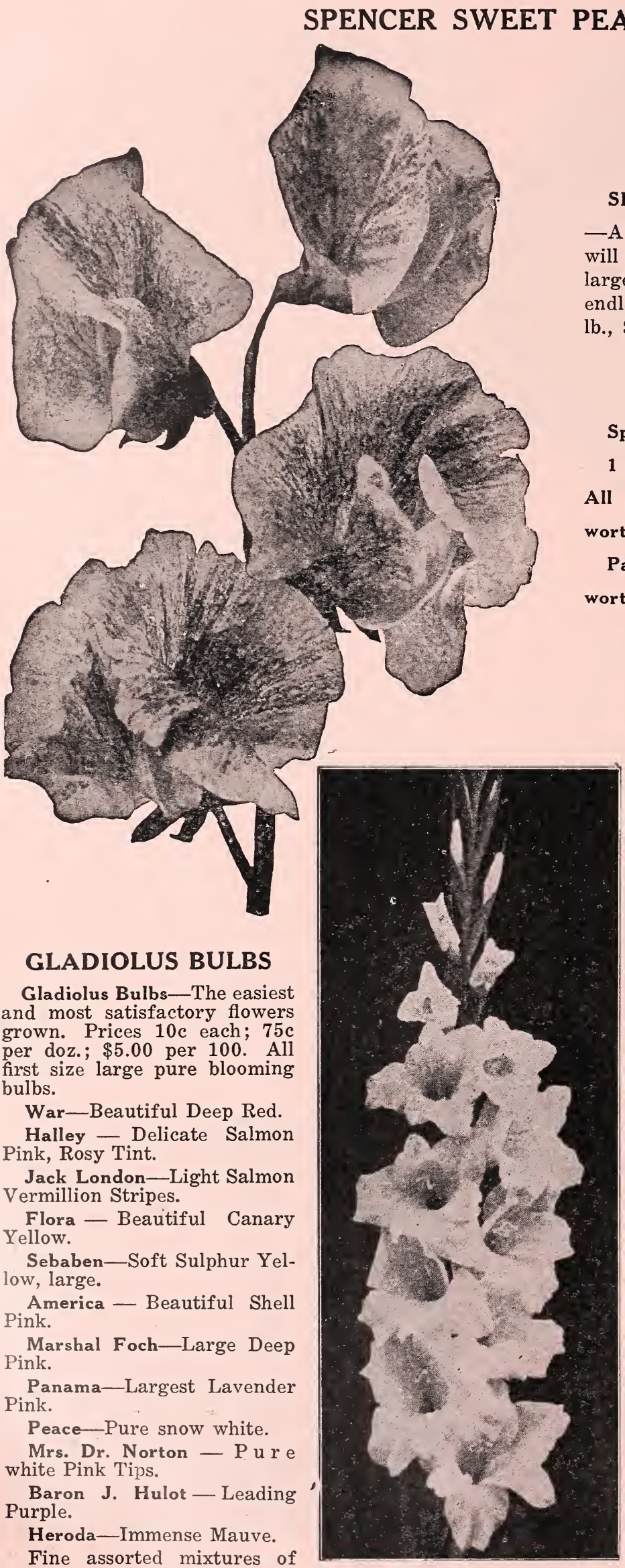

Gladiolus

\section{SPLENDID SPENCER MIXTURE}

-A fine blend of the better sorts; it will produce a lavish display of the largest and most attractive flowers in endless variety. Oz., 25c; $1 / 4 \mathrm{lb} ., 75 \mathrm{c}$; lb., $\$ 2.00$; pkt., 10 c.

\section{Special Collections of Sweet Peas.}

1 packet each of 16 Best varieties.

All different. Splendid assortment worth $\$ 1.65$, for $\$ 1.00$.

Packet any seven varieties listed worth 75 c for $50 c$.

Aurora - Whit e ground, striped and flaked orange and pink.

Blanche Ferry-Bright rose, wings white flushed pink.

Campfire - The brightest scarlet sunproof of all the Spencers. The last word in vivid color.

Countess Spencer - A lovely pale pink, with darker edges.

Fiery Cross-A deep shade of flame-like orange-scarlet.

Florence Morse-White with delicate soft pink edge.

Geo. Herbert - Magnificent rich rosy carmine.

Illuminator-Glowing salmonorange suffused with cerise.

King Edward-D e e $p$ rich crimson scarlet.

Margaret Atlee (Improved) -A beautiful glowing rosepink.

Margaret Madison - Light lavender or azure-blue.

Mrs. Routzahn-Apricot, suffused with pink.

Othello-A very deep maroon, waved, giving a very rich effect.

Royal Purple-The finest rich royal purple.

Wedgwood-Silvery blue. Of exquisite form and very freeflowering.

White Spencer-The best of the Spencer varieties. The flowers are very large and magnificently waved form. 


\section{HARDY FRUITS FOR THE HOME GARDEN}

Below we have compiled a select list of nor'hern grown Trees and Bushes that are invaluable for home use. We have selected the best of the respective varieties that are sure to give satisfaction. These are offered in the dormant state only and can be supplied from March 15th to May 1st, depending on the weather conditions.

The small Fruits can be mailed at purchaser's expense, but on account of the size, Fruit trees are sent by express only, customer paying charges.

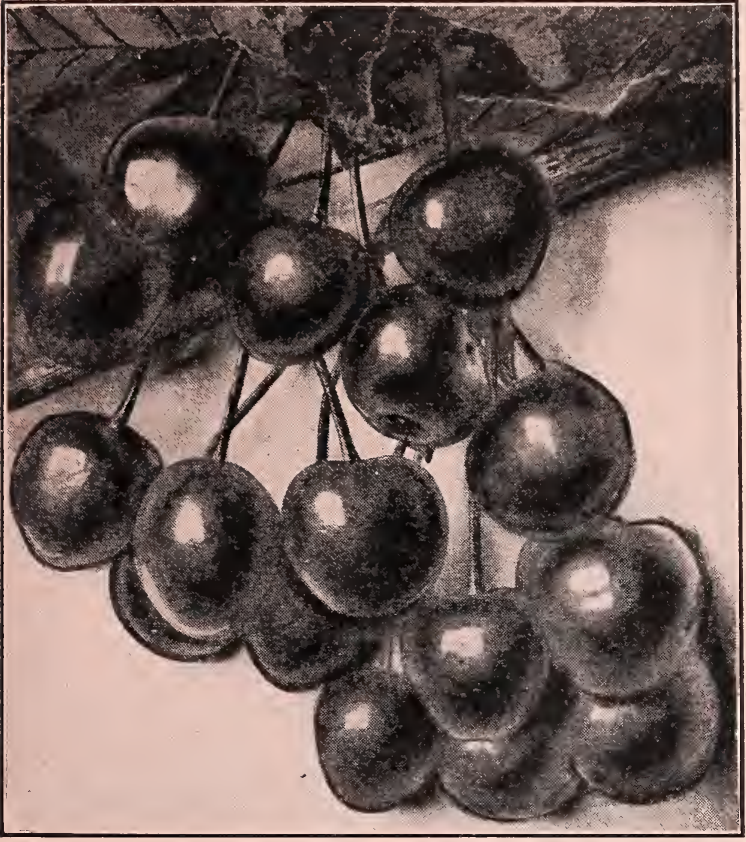

Black Tartarian Cherries

\section{APPLES}

First Class Standard Trees: 5-7 ft. each $75 \mathrm{c} ; 10$ for $\$ 6.50 ; 4-6 \mathrm{ft}$. each $60 \mathrm{c}$; ten for $\$ 5.00$; 4-5 ft. each $50 \mathrm{c}$; ten for $\$ 4.00$.

\section{SUMMER APPLES}

Duchess of Oldenburgh-Large, striped Red and Yellow.

Gravenstein-Large, striped with Red.

Red Astrachen-Crimson, fine for family use.

Yellow Transparent-Earliest variety. Bears very young.

\section{AUTUMN APPLES}

Fall Pippin-Very large. Yellow, splendid quality.

McIntosh Red-Most popular variety, dark Red, crisp white flesh of highest quality.

Opalescent - Very large. Crimson, early abundant bearer.

Wealthy-Handsome early fruiting variety.

\section{WINTER APPLES}

Baldwin-Too well known to need description.

Courtland-New variety similar to McIntosh. Later.

Delicious-Large and of high quality recommended as one of seven best varieties to plant.

King-Red. Largest size and best quality.

Northern Spy-Large striped with red.

Rhode Island Greening - Large. Tender, juicy. ing.

\section{PEACH TREES}

4 to $6 \mathrm{ft}$. each $50 \mathrm{c}, 10$ for $\$ 4.50,100$ $\$ 25.00$.

3 to $4 \mathrm{ft}$. each $40 \mathrm{c}, 10$ for $\$ 3.50,100$ $\$ 20.00$.

Varieties in order of their ripening.

Greensboro-Earliest, white clings.

Carman-Hardy, white, red cheek, semicling.

Champion-Handsome creamy white, red cheek.

Belle of Ga.-Standard, white, large size, free.

Elberta-Large yellow, free; Popular.

J. H. Hale-Very large yellow, good quality

Stump the World-Old white freestone.

\section{PEAR TREES}

5 to $7 \mathrm{ft}$. each $\$ 1.25,10$ for $\$ 8.00$.

5 to $6 \mathrm{ft}$. each $\$ 1.00,10$ for $\$ 7.00$.

4 to $5 \mathrm{ft}$. each $75 \mathrm{c}, 10$ for $\$ 6.00$.

\section{SUMIMER PEARS}

Bartlett-Large, Yellow, September.

Clapp's Favorite - Very large, Yellow and Crimson, August.

Wilder-Bright yellow, virtually coreless.

\section{AUTUMN PEARS}

Anjou-Large, yellow. Winter Pear.

Seckel-Small, brown, juicy.

Sheldon-Large, Russet and red.

\section{CRAB APPLES}

Trees, 5 to $7 \mathrm{ft}$. each $75 \mathrm{c} ; 10$ for $\$ 6.50$.

Hyslop-Large. Dark Crimson. H e a v y bloom; most beautiful of all the class.

Transcendant-Largest size crabapple, red, showy, excellent and very handsome.

\section{QUINCES}

Trees, 3 to $4 \mathrm{ft}$. each $\$ 1.00,10$ for $\$ 10.00$. Champion - Most vigorous and productive variety.

\section{PLUMS}

4 to $6 \mathrm{ft}$. each $75 \mathrm{c}, 10$ for $\$ 7.00$.

5 to $7 \mathrm{ft}$. each $\$ 1.00,10$ for $\$ 9.00$.

Bradshaw-Large, oval, dark violet red.

Coe's Golden Drop-Very large, light yellow.

Lombard-Medium oval; violet red, juicy.

\section{JAPAN PLUMS}

Abundance-Lemon yellow, cheeks bright cherry.

Burbank - Large, beautiful, clear cherry red.

Red June-Earliest plum to ripen; skin red; flesh yellow.

\section{CHERRY TREES}

5 to $7 \mathrm{ft}$. each $\$ 1.00,10$ for $\$ 8.50$.

5 to $6 \mathrm{ft}$. each $75 \mathrm{c}, 10$ for $\$ 7.00$.

Black Tartarian-Best dark red variety.

Governor Wood-Light yellow, red cheek.

Schmidt's Biggareau - Very large dee black.

Yellow Spanish-Beautiful light yellow heart.

Montmorency - Most popular hardy soux

cherry, splendid for pies or canning. 


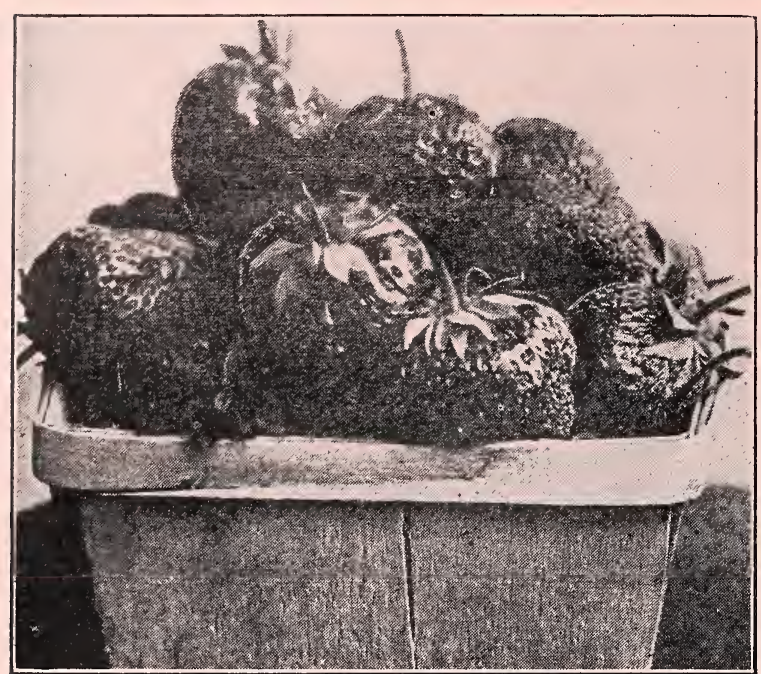

Howard 17 Strawberries

\section{STRAWBERRIES}

100 for $\$ 1.00,1,000$ for $\$ 7.50$. $\mathrm{P}$-indicates Perfect; I-imperfect flower. Brandywine - (P) Late, fine for canning. Gibson-(P) Dark rich.

Glen Mary-(P) Choice variety, large and vigorous.

Howard 17-(P) Most popular. Best early berry.

New York-(P) Large fancy mid-season variety.

Wm. Belt-(P) Late large fancy berries.

\section{RASPBERRIES}

65 c per $10, \$ 4.00$ per $100, \$ 30.00$ per 1,000 . Black Varieties

Plum Farmer-The most popular.

Cumberland - Later than Plum Farmer. Large.

\section{Red Varieties}

Columbian Purple-Strong, thrifty. Fine for canning.

Cuthbert-Standard of highest quality.

St. Regis-Bears a crop on young canes in the Fall.

Latham-The newest and best of the red varieties. Hardy and popular everywhere.

Price of Latham, 10 for $\$ 1.00 ; 100$ for $\$ 6.00$.

\section{BLACKBERRIES}

Ten for $65 \mathrm{c}$, Hundred $\$ 4.00$.

Eldorado-Bears heavily; large, sweet berries.

Snyder-Medium size, quality fine; hardy.

Mersereau - Berries exceptionally sweet, enormous yielders.

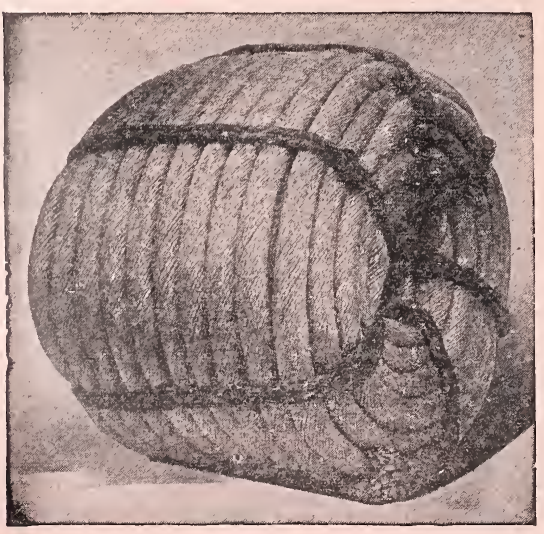

\section{HOT BED MATS}

Burlap both sides

$76 \times 84$ in. Doz. $\$ 36.00$

Prices are F. O. B. Connecticut, net cash with order.

Tying Twine
GRAPES, HARDY VARIETIES

25 c each, 10 for $\$ 2.50,100$ for $\$ 20.00$.

$$
\text { BLACK }
$$

Concord-Large, always reliable. sweet.

Wilder (Roger's No. 4) - Very large.

Worden-Large, excellent quality. Early.

\section{RED}

40 c each, 10 for $\$ 3.50,100$ for $\$ 30.00$.

Brighıon-Large, best quality. Early.

Delaware-Small, delicious. Late.

$$
\text { WHITE }
$$

30 c each, 10 for $\$ 2.50,100$ for $\$ 20.00$. $75 \mathrm{c}$ each.

Moore's Diamond - Large, excellent. .

Niagara-Large and productive. Medium. CURRANTS

25 c each, 10 for $\$ 2.00$.

Fay's Prolific - Almost as large as a Cherry. red.

Note: Cannot send currants outside of Connecticut.

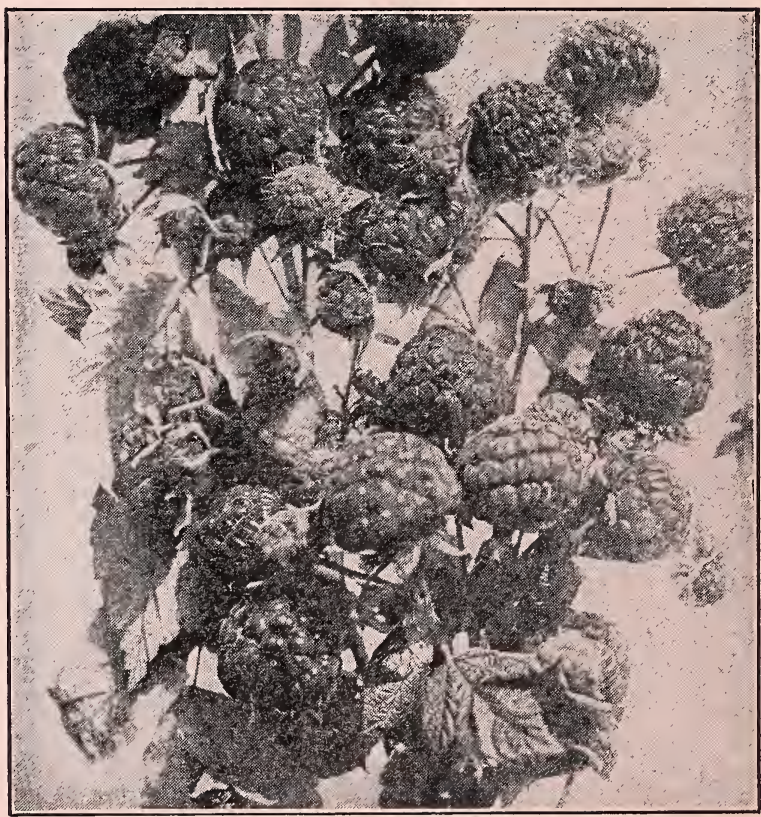

\section{Latham Raspberries}

\section{TYING TWINE} (100 strings in the rope) and wound on a reel the same as barbed wire. In this manner it never becomes snarled and enables one to cut out a hundred strings any desired length instantly. 2-3 and 4-ply (state which).

Price per reel of $50 \mathrm{lbs} ., 24 \mathrm{c} \mathrm{p}^{\circ r} \mathrm{lb}$.

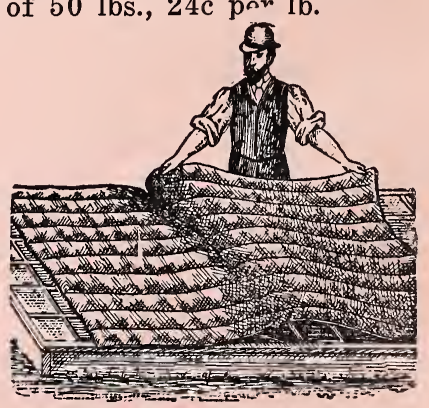




\section{WOODRUFF'S HOME MIXED FERTILIZER}

We have mixed our own fertilizer for use on our extensive seed farms for the past few years and cannot too strongly recommend this method of buying fertilizers. The successful results we have obtained from using Woodruff's Home Mixture on our own farms has induced us to offer these goods at a reasonable price to the dozens of our customers who quickly see the extra value offered. The fertilizer we offer is in every respect the same as we use on our own extensive farms, is made from strictly high-grade chemicals and mixed by ourselves. We buy these chemicals in 50 or 100 ton lots for spot cash, and by so doing we are enabled to sell a strictly highgrade fertilizer at a much lower price than the same quality can be purchased from manufacturers of ready mixed fertilizers.

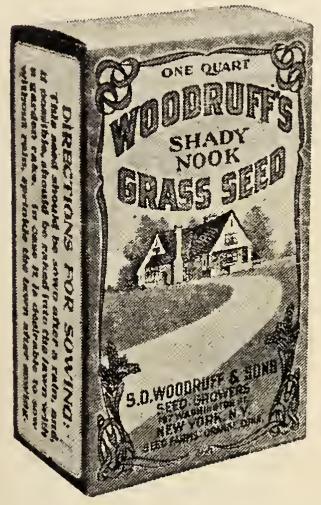

SHEEP MANURE (For Lawn Dressing) ANALYSIS

Ammonia ........................... 2.50\%

Soluble Potash .................... 2.00\%

Phosphoric Acid ................. 1.00\%

(Odorless, easy to apply, quick acting)

100 lb. package ....................\$ 3.00

Ton in $100 \mathrm{lb}$. bags .............. 50.00

\section{BONE MEAL}

100 lb. package

Ton in $100 \mathrm{lb}$. bags

$\$ 3.25$

60.00
WOODRUFF'S HOME MIXED FERTILIZERS

We offer the following formula: Ammonia ......................... 4.00\% Available Phosphoric Acid $8.00 \%$ Potash .............................. 6.00\%

Spot Cash Price, $\$ 45.00$ Per Ton, F. O. B. Orange, Connecticut.

Per 100 lbs. \$3.00; Per 500 lbs. $\$ 12.00$

Nitrate of Soda in original bags, about $200 \mathrm{lbs}$. each, at $\$ 4.00$ per 100 lbs.; $\$ 75.00$ per ton.

Ground Castor Pomace guaranteed, $5 \frac{1}{2} \%$ Ammonia, at $\$ 2.50$ per 100 lbs.
A c i d Phosphate, guaranteed 16\% available Phosphoric Acid, at $\$ 1.50$ per 100 lbs.; $\$ 24.00$ per ton.

Muriate of Potash, $\$ 3.00$ per 100 lbs.; $\$ 50.00$ per ton.

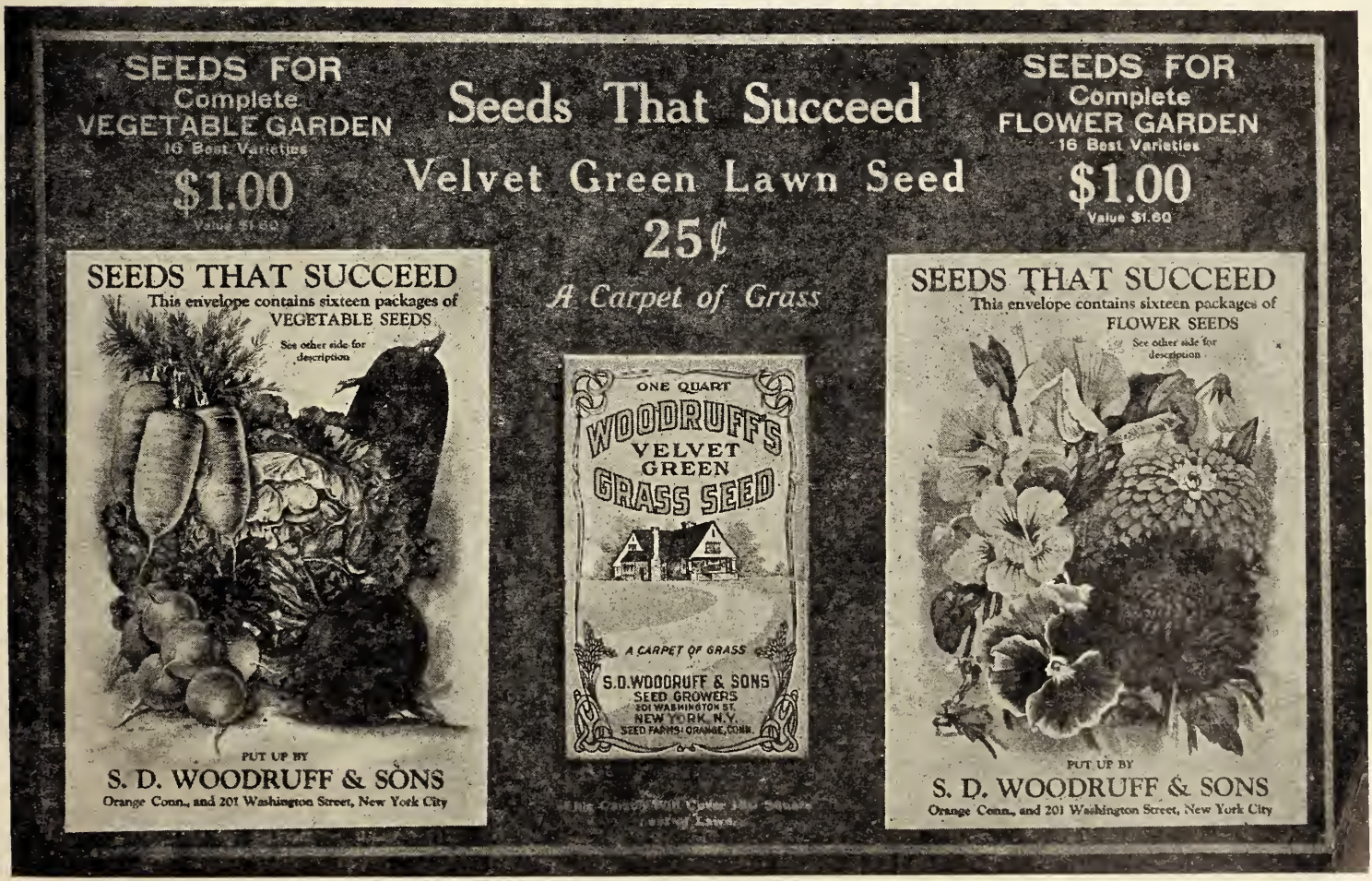

COMPLETE FLOWER GARDEN \$1.00 - - -
A Carefully Selected Assortment of the Best and Most Useful Hardy Flowers that are Easy to Grow. A Large Package each of 16 Different Flowers. Better Assortment than the Amateur would Select.

Collection Contains: Cosmos, Early Flowering Mixed; Phlox, Drummondi; Zinnias, Tall Double Mixed; Verbena, Mixed; Snapdragon, Antirrhinium Mixed; Sweet Peas, Spencer Mixed; Balsam, Camelia Flowering Mixed; Nasturtium, Mixed; Dianthus, Mixed; Centaurea, Blue Batchelor Button; Candytuft, Mixed; Aster, Mixed; Gyysophila; Eschscholtzia Cal. Poppy; Larkspur, Mixed; Pansy, Mixed. 


\section{S.D.WOODRUFF \& SONS, SEEDSMEN \\ ORANGE, CONNECTICUT AND 201 WASHINGTON ST. NEW YORK}

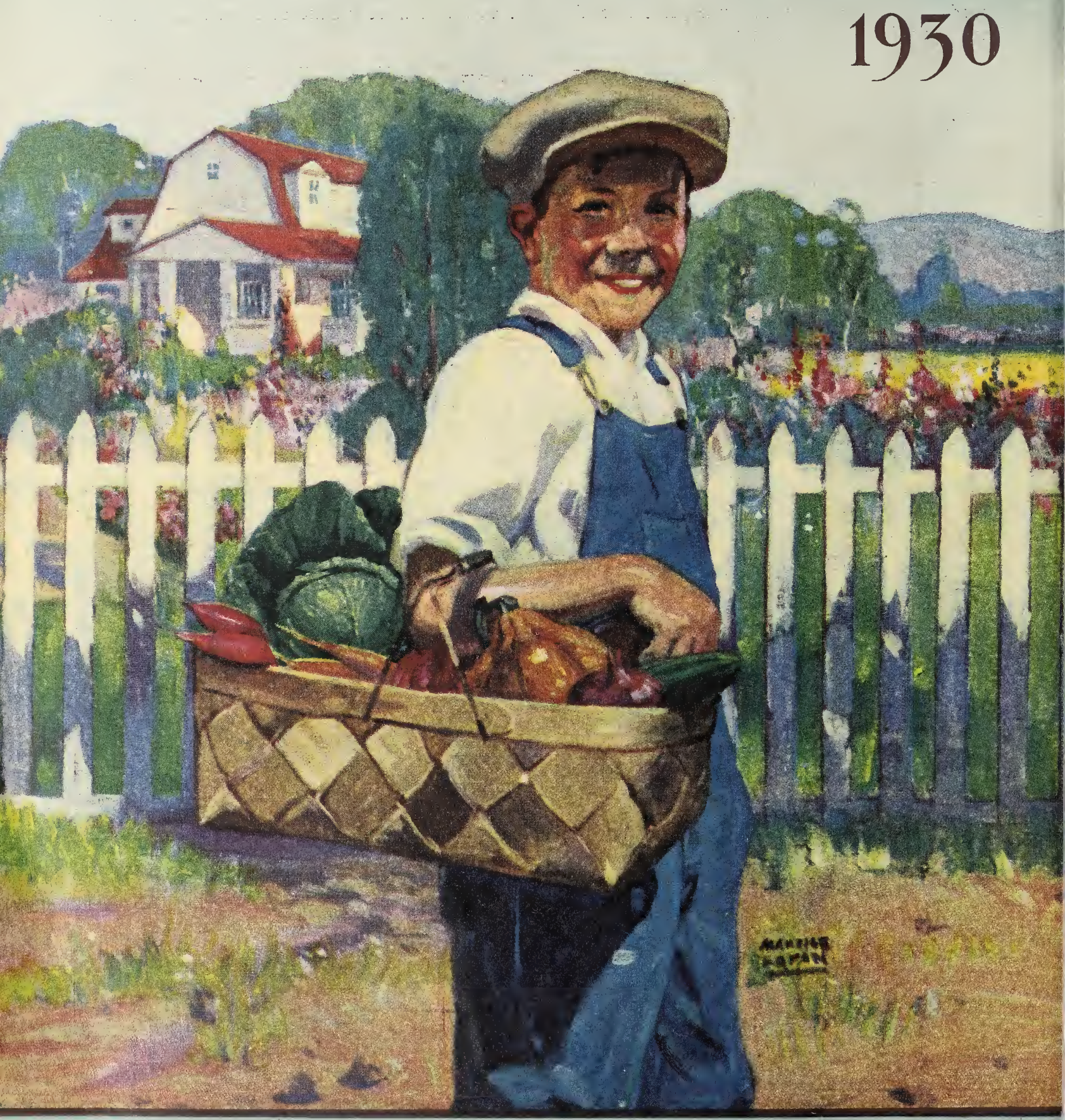

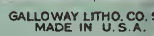

PKT. 10 